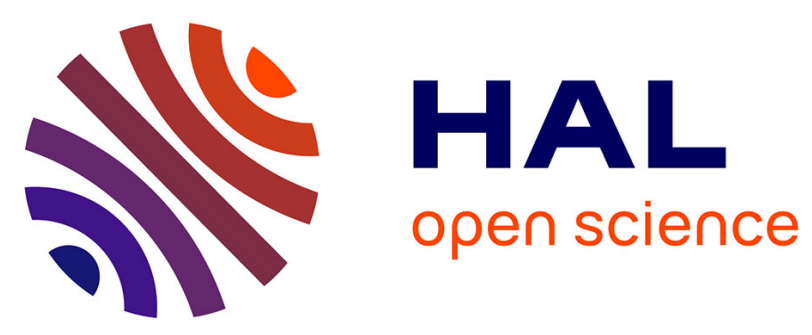

\title{
The role of sulphur on the melting of Ca-poor sediment and on trace element transfer in subduction zones: an experimental investigation
}

\author{
Anne-Aziliz Pelleter, Gaëlle Prouteau, Bruno Scaillet
}

\section{To cite this version:}

Anne-Aziliz Pelleter, Gaëlle Prouteau, Bruno Scaillet. The role of sulphur on the melting of Ca-poor sediment and on trace element transfer in subduction zones: an experimental investigation. Journal of Petrology, 2021, 62 (9), pp.egab005. 10.1093/petrology/egab005 . insu-03143260

HAL Id: insu-03143260

https://hal-insu.archives-ouvertes.fr/insu-03143260

Submitted on 16 Feb 2021

HAL is a multi-disciplinary open access archive for the deposit and dissemination of scientific research documents, whether they are published or not. The documents may come from teaching and research institutions in France or abroad, or from public or private research centers.
L'archive ouverte pluridisciplinaire HAL, est destinée au dépôt et à la diffusion de documents scientifiques de niveau recherche, publiés ou non, émanant des établissements d'enseignement et de recherche français ou étrangers, des laboratoires publics ou privés. 


\title{
The role of sulphur on the melting of Ca-poor sediment and on
}

\section{trace element transfer in subduction zones: an experimental investigation}

Anne-Aziliz Pelleter ${ }^{1}$, Gaëlle Prouteau ${ }^{1 *}$, Bruno Scaillet ${ }^{1}$

\begin{abstract}
${ }^{1}$ Institut des Sciences de la Terre d'Orléans (ISTO), UMR 7327, Université d'Orléans, CNRS, BRGM, F-45071 Orléans, France
\end{abstract}

*Corresponding author.E-mail: gaelle.prouteau@cnrs-orleans.fr

\section{ABSTRACT}

We performed phase equilibrium experiments on a natural Ca-poor pelite at $3 \mathrm{GPa}, 750$ $1000^{\circ} \mathrm{C}$, under moderately oxidizing conditions, simulating the partial melting of such lithologies in subduction zones. Experiments investigated the effect of sulphur addition on phase equilibria and compositions, with S contents of up to $\sim 2.2$ wt. $\%$. Run products were characterized for their major and trace element contents, in order to shed light on the role of sulphur on the trace element patterns of melts produced by partial melting of oceanic Ca-poor sediments. Results show that sulphur addition leads to the replacement of phengite by biotite along with the progressive consumption of garnet, which is replaced by an orthopyroxenekyanite assemblage at the highest sulphur content investigated. All Fe-Mg silicate phases produced with sulphur, including melt, have higher $\mathrm{MgO} /(\mathrm{MgO}+\mathrm{FeO})$ ratios (relative to Sfree/poor conditions), owing to Fe being primarily locked up by sulphide in the investigated redox range. Secular infiltration of the mantle wedge by such $\mathrm{MgO}$ and $\mathrm{K}_{2} \mathrm{O}$-rich melts may 
have contributed to the $\mathrm{Mg}$ and $\mathrm{K}$-rich character of the modern continental crust. Addition of sulphur does not affect significantly the stability of the main accessory phases controlling the behaviour of trace elements (monazite, rutile and zircon), although our results suggest that monazite solubility is sensitive to $\mathrm{S}$ content at the conditions investigated. The low temperature $\left(\sim 800^{\circ} \mathrm{C}\right) \mathrm{S}$-bearing and Ca-poor sediment sourced slab melts show $\mathrm{Th}$ and $\mathrm{La}$ abundances, Th/La systematics and HFSE signatures in agreement with the characteristics of sediment-rich arc magmas. Because high S contents diminish phengite and garnet stabilities, S-rich and Ca-poor sediment sourced slab melts have higher contents of Rb, B, Li (to a lesser extent), and HREE. The highest ratios of $\mathrm{La} / \mathrm{Yb}$ are observed in sulphur-poor runs (with a high proportion of garnet, which retains HREE) and beyond the monazite out curve (which retains LREE). Sulphides appear to be relatively $\mathrm{Pb}$-poor and impart high $\mathrm{Pb} / \mathrm{Ce}$ ratio to coexisting melts, even at high S content. Overall, our results show that Phanerozoic arc magmas from high sediment flux margins owe their geochemical signature to the subduction of terrigenous, sometimes S-rich, sediments. In contrast, subduction of such lithologies during Archean appears unlikely or unrecorded.

Key words: arc magmas; experimental petrology; sediment melting; sulphur cycle; trace elements geochemistry 


\section{INTRODUCTION}

Arc volcanism has been a prominent source of sulphur to the atmosphere during much of geological time. Restored sulphur contents of arc magmas prior to eruption yield bulk S contents at ca 0.5 wt. \%, reaching several wt. \% in some instances (Scaillet \& Pichavant, 2003). High sulphur concentrations (typically 900-2500 ppm, but values extend as high as $7000 \mathrm{ppm}$ ) in silicate-melt inclusions hosted in olivine from arc harzburgitic xenoliths or primitive basaltic lava samples from convergent settings also indicate that arc mantle may be significantly enriched in sulphur (up to $500 \mathrm{ppm}$ ) relative to MORB (Mid-Ocean Ridge Basalt) source mantle (ca 120 ppm, Salters \& Stracke, 2004) (Métrich et al., 1999; de Hoog et al., 2001a; Cervantes \& Wallace, 2003; Wallace \& Edmonds, 2011). This suggests large-scale fluxing of sulphur into the mantle wedge, transported by an $\mathrm{H}_{2} \mathrm{O}$-rich agent with up to several wt. \% sulphur (Cervantes \& Wallace, 2003). The main contributor to the sulphur budget of subduction zones is altered ocean crust (AOC) $\left(1.5 \times 10^{12} \mathrm{~mol}_{\text {year }}^{-1}\right)$, followed by serpentinite $\left(0.68 \times 10^{12} \mathrm{~mol} \mathrm{year}^{-1}\right)$ and sediments $\left(0.62 \times 10^{12}\right.$ mol year $\left.^{-1}\right)$, which contribute to $\sim 20 \%$ of the total input (Evans, 2012). The estimate for sediments is based on an assumed value for the total subducted sediment flux of $1.73 \times 10^{12} \mathrm{~kg}_{\text {year }}{ }^{1}$, which includes 8 wt. \% water and a maximum S content of 1.15 wt. \% (Evans, 2012). This estimated sulphur budget suggests that $\sim 15$ wt. \% of subducted sulphur is recycled by arc magmatism (Evans, 2012). For instance, Li et al. (2020) have shown, based on the Tianshan high pressure-low temperature terrane study, that dehydration-related fluids transfer up to $20 \mathrm{wt} . \%$ of total subducted sulphur from the slab to the mantle wedge. Sulphur isotopes in arc volcanoes suggest moreover that subducted oceanic sediment is a likely and significant source for the $\mathrm{S}$ enrichment observed in arc magmas (Alt \& Burdett, 1992; de Hoog et al., 2001b; Bouvier et al. 2008), although the 
isotopic signature of the sediment component that ultimately contribute to magma source is difficult to predict (e.g. Evans et al., 2014).

Traditionally, hydrous fluids are thought to transport sulphur from the subducting slab to the site of melting in the mantle wedge (e.g. Tomkins \& Evans, 2015; Jégo \& Dasgupta, 2013; Walters et al., 2019; Li et al., 2020). Sulphur exhibits low solubility in silicic melts at low pressure and temperature (e.g. Luhr, 1990; Carroll \& Webster, 1994; Scaillet et al., 1998), and consequently silicate melts were usually considered not to be an efficient agent of sulphur extraction from the slab. However, experimental works have demonstrated that the sulphur content of high pressure oxidized hydrous silicic melts is at least 10-20 times higher than at low pressures (Prouteau \& Scaillet, 2013; Jégo \& Dasgupta, 2014; Canil \& Fellows, 2017; D’Souza \& Canil, 2018; Li et al., 2019). This finding reduces the restriction that the sulphur-rich character of present-day arc volcanism bears evidence solely of a sulphur-rich hydrous fluid. The most extreme sulphur content in these recent studies was achieved with a pelite (of the same composition as our starting product) doped with $4 \mathrm{wt}$. \% elemental S at 3 $\mathrm{GPa}$, conditions under which the felsic silicate melt dissolved nearly 1 wt. \% sulphur at $900^{\circ} \mathrm{C}$ (Prouteau \& Scaillet, 2013). Sulphur has been shown to affect the stabilities of phases other than those S-bearing, i.e. amphibole, biotite in magmas (Scaillet \& Evans, 1999; Costa et al., 2004; Prouteau \& Scaillet, 2013; Canil \& Fellows, 2017; D’Souza \& Canil, 2018). It is thus important to assess the role of $\mathrm{S}$ on the stability of phases of subducted sediments in order to evaluate its potential effect on trace element patterns.

Within this context, this study aims at exploring the phase relationships and compositions (major elements, trace elements, sulphur content) during the high pressure hydrous melting of a Ca-poor natural sediment both with and without $\mathrm{S}$ so as to constrain the role of the latter on the geochemical pattern of arc magmas. The trench sediment is largely dominated by terrigenous sediments and has a geochemical composition very similar to the 
post-Archean average shales and the upper continental crust (Plank \& Langmuir, 1998). Piston-cylinder experiments were performed in the temperature range 750 to $1000^{\circ} \mathrm{C}$ at 3 GPa. Such P-T conditions are inferred to prevail at the top of the subducted slab beneath the majority of active volcanic arcs (e.g. Syracuse et al., 2010), and are thus supposed to mimic slab melting nowadays. Our experiments were designed to test flux-melting mechanism by using starting materials in which $\mathrm{H}_{2} \mathrm{O}$ contents $\left(\sim 8.5\right.$ to 15 wt. $\left.\% \mathrm{H}_{2} \mathrm{O}\right)$ exceed the water budget of hydrous minerals, under moderately oxidized conditions. We explored a range of bulk sulphur content, from $\sim 900 \mathrm{ppm}$ up to $\sim 2.2$ wt. \%. Estimates of the sulphur content of subducting sediments or exhumed sediment eclogites are sparse. Goldhaber (2003) reported total sulphur abundance in recent marine sediments (exclusive of sediment deposited under anoxic conditions and those dominated by a carbonate matrix) varying from $\sim 0.1 \mathrm{wt} . \%$ to greater than 2 wt. \%. Metapelites in the Tianshan HP metamorphic belt have $[\mathrm{S}]_{\mathrm{wr}}=1101-$ $5612 \mathrm{ppm}$ which are the highest whole-rock sulphur concentrations of high pressure (HP) exhumed slab rocks (including eclogite and serpentinites) reported so far (Li et al., 2020). Evans (2012), following the approach of Canfield (2004), assumes that approximately $1 \mathrm{wt} . \%$ Fe in deep sea sediments is available for pyrite formation, which gives a $\mathrm{S}$ content for these sediments of $1.15 \mathrm{wt} . \%$ (maximum value for the case where all subducting sediments have undergone pyrite formation in the sulphide stability field, and given a $50 \%$ relative uncertainty). Therefore, natural variation in sediment S content (measured or estimated), although poorly constrained, is roughly of the same order of magnitude as the range of variation explored in our experiments.

Experimental charges were analysed by EPMA (Electron Probe Microanalysis) and LA-ICP-MS (Laser Ablation Inductively Coupled Plasma Mass Spectrometry). Our results are then applied to subduction zone magmatism, in an effort to unravel the role of such sediment-sourced slab melt on the geochemical signature of arc magmas (and continental 
crust). Below, in order to put our results in a broader perspective, we first review in some detail the main geochemical characteristics of arc magmas, focusing on trace elements commonly used in the geochemical community, and their main mineral carriers including micas, garnet, monazite, zircon and rutile.

\section{KEY GEOCHEMICAL FEATURES OF ARC MAGMAS}

There is a consensus that key geochemical features of island arc basalt (IAB) (e.g. the lower abundances of HFSE (High Field Strength Elements ) relative to the LREE (Light Rare Earth Elements) and LILE (Large Ion Lithophile Elements), with respect to MORB are controlled by the addition of slab-derived fluids of various nature (fluids, melts or supercritical liquids, e.g. Schmidt \& Jagoutz, 2017) to the peridotitic mantle wedge. A single slab component, much beloved for its simplicity, is often advocated, but detailed studies on individual arcs as well as global surveys of primitive arc magma compositions have led to the inescapable conclusion that in many, if not all, arcs there are (at least) two discrete slab components (expelled from subducted sediment and altered oceanic crust, respectively) added, with variable contribution, to a depleted mantle (e.g. Kay, 1980; Ellam \& Hawkesworth, 1988; Plank \& Langmuir, 1992; McDermott et al., 1993; Miller et al., 1994; Regelous et al., 1997; Turner et al., 1997; Class et al., 2000; Elliott, 2003; Schmidt \& Jagoutz, 2017). The "sediment-starved" arc magmas typically have low concentrations of incompatible elements when compared with those in sediment-rich arcs and exhibit low $\mathrm{La} / \mathrm{Sm}$ and high $\mathrm{Ba} / \mathrm{Th}$ and $\mathrm{U} / \mathrm{Th}$ ratios, common activity excess of ${ }^{238} \mathrm{U}$ over ${ }^{230} \mathrm{Th}$, as well isotopic signatures consistent with contributions from an altered MORB source (Hawkesworth et al., 1997; Elliott, 2003). Therefore, transport of material from altered mafic oceanic crust to the arc lava source needs to selectively fractionate elements that are highly incompatible during mantle melting (e.g. $\mathrm{Ba}$ 
from Th or $\mathrm{U}$ from $\mathrm{Th})$. These characteristics have been traditionally ascribed to an aqueous fluid, selectively enriched in "mobile" elements such U and Ba, derived from the altered oceanic crust (e.g. Elliott et al., 1997; Elliott, 2003; Pearce et al., 2005). However, Carter et al. $(2015)$ and Skora et al. $(2015,2017)$ have demonstrated that oceanic crust or carbonatedsediment can contribute high pressure melts with high ratios of $\mathrm{Ba} / \mathrm{Th}$ and $\mathrm{U} / \mathrm{Th}$. Such a process could also explain the high $\mathrm{Ba} / \mathrm{Th}$ and $\mathrm{U} / \mathrm{Th}$ ratios observed in high-pressure exhumed mélange zones; these mélanges are interpreted as blobs of low density diapirs (made of variable amount of crust+sediment+mantle) formed at the slab-mantle interface and transported into the hot corner of the mantle wedge beneath arcs (e.g. Marschall \& Schumacher, 2012).

Arc magmas dominated by a sediment component are characterized by low $\mathrm{Ba} / \mathrm{Th}$ or $\mathrm{U} / \mathrm{Th}$ ratios and high $\mathrm{La} / \mathrm{Sm}$ ratio associated with very high incompatible elements, such as $\mathrm{Th}$ and LREE (e.g. Hawkesworth et al., 1997; Elliott, 2003). They plot generally either close to the equiline or sporadically towards slight Th activity excess on a ${ }^{230} \mathrm{Th} /{ }^{232} \mathrm{Th}$ versus ${ }^{238} \mathrm{U} / 232$ Th diagram (e.g. Condomines \& Sigmarsson, 1993; Elliott et al., 1997; Hawkesworth et al., 1997; Turner et al., 2012). A high concentration of ${ }^{10} \mathrm{Be}$ in arc lavas is an unequivocal indicator of the contribution of subducting sediments (e.g. Morris et al., 1990). Additionnaly, sediment partial melting is required for critical elements such as Th and Be to be efficiently transferred into the mantle wedge (Johnson \& Plank, 1999; Hermann \& Spandler, 2008; Hermann \& Rubatto, 2009) though this remains debated (e.g. Kessel et al., 2005; Schmidt \& Poli, 2014). Plank and Langmuir (1993, 1998) and Plank (2005) have demonstrated moreover that the ratios of key incompatible elements (e.g. Th/La) at various arcs worldwide correspond closely to the subducted sediment signatures, which implies that this ratio is not, or weakly, fractionated during sediment melting. Skora et al. $(2015,2017)$ have shown that, for slab-top temperatures compatible with recent numerical models, LREE and Th fluxes entering the arc 
basalt source region from Ca-rich sediments is negligible, owing to residual epidote and/or carbonate in such lithologies. The LREE and Th enrichment in arc magmas must therefore originate from the Ca-poor sedimentary veener, a hypothesis explored in our experiments.

The unique and ubiquitous HFSE negative anomaly in arc magmas is traditionally ascribed to the HFSE depletion, relative to other elements of comparable incompatibility, of the fluid component(s) leaving the slab. The negative $\mathrm{Nb}$ (and $\mathrm{Ta}$ ) anomaly becomes even more pronounced in sediment-rich subduction zones, even though $\mathrm{Nb}$ abundances are higher in these contexts. Although most oceanic sediments show negative $\mathrm{Nb}$ anomalies, to generate the source of the enriched arc lavas requires the addition of a component with even higher $\mathrm{Th} / \mathrm{Nb}$ than the subducting sediment (Elliott, 2003). The $\mathrm{Nb} / \mathrm{Ta}$ ratios of mafic arc magmas (e.g. Münker et al., 2004), as that of most accessible silicates, including the bulk continental crust (e.g. Barth et al., 2000), are lower than the chondritic value of 17.5 (Jochum et al., 2000) or 19.9 (Münker et al., 2003). There have been several attempts to identify reservoirs with super-chondritic $\mathrm{Nb} / \mathrm{Ta}$ to solve this imbalance (see Stepanov \& Hermann (2013) and references therein). One hypothesis is that the sub-chondritic nature of the bulk silicate Earth is a feature that was inherited within the first 100 million years of Earth's history, perhaps via preferential sequestration of $\mathrm{Nb}$ into the core during planetary accretion (Wade \& Wood, 2001; Münker et al., 2003; Tang et al., 2019). The other is that there is a hidden reservoir of refractory rutile-bearing eclogites with super-chondritic $\mathrm{Nb}$ /Ta ratios in the deep mantle to counterbalance the continental crust and depleted mantle (Kamber \& Collerson, 2000; Rudnick et al., 2000; Xiong et al., 2011). The low $\mathrm{Nb} / \mathrm{Ta}$ ratios are in this case inherited from the source, such as through slab melting (e.g. Xiong et al., 2011) or through differential transport in hydrous fluids. Below we explore these last two hypotheses in the light of our experimental results. 
Since the pioneering work of White \& Patchett (1984), many isotopic studies have concluded that subduction and recycling of marine sediments contribute to the Hf-Nd composition of arc magmas (e.g. Carpentier et al., 2009; Chauvel et al., 2009). Zircon is the main carrier of $\mathrm{Zr}$ and $\mathrm{Hf}$ in detrital sediment (e.g.van de Flierdt et al., 2007; Chen et al., 2011). Given the low solubility of zircon in aqueous fluids (e.g. Ayers et al., 1991; Kovalenko \& Ryzhenko, 2009), some authors have proposed that sediment melts transfer efficiently their isotopic signature to the source of magma (e.g. Woodhead et al., 2001; Carpentier et al., 2009; Nebel et al., 2011). The dissolution of zircon moreover controls the $\mathrm{Zr} / \mathrm{Hf}$ and $\mathrm{Lu} / \mathrm{Hf}$ ratios of the slab fluid, which may further help to unravel the isotopic sediment signature.

Finally, arc magmas are characterized by a marked enrichment in $\mathrm{Pb}$ compared to the HFSE and REE. The $\mathrm{Ce} / \mathrm{Pb}$ ratio in arc basalts and average continental crust $(\sim 3)$ is considerably below that of oceanic basalts $(\sim 25)$ and of the bulk Earth $(\sim 10)$. This geochemical signature is classically attributed to the fluxing of the mantle wedge by low $\mathrm{Ce} / \mathrm{Pb}$ hydrous fluids of various salinities, generated by the dehydration of subducted lithologies (e.g. Brenan et al., 1995; Chauvel et al., 1995; Keppler, 1996; Kessel et al., 2005a). Pb isotopic compositions provide definitive evidence of a sediment contribution (e.g. Miller et al., 1994; Gertisser \& Keller, 2003; Carpentier et al., 2008). Previous studies have shown that $\mathrm{Ca}$-poor, sediment-derived, hydrous melts successfully fractionate $\mathrm{Pb}$ from $\mathrm{Ce}$ (e.g. Johnson \& Plank, 1999; Hermann \& Rubatto, 2009). As Pb is a nominally chalcophile element, one can expect a different behaviour in sulphur-rich systems, that can be evaluated in our experiments.

\section{EXPERIMENTAL AND ANALYTICAL PROCEDURES}




\section{Rationale}

Several experimental studies have focused on the trace element signature of Ca-poor sediment melts in subduction zones by using either synthetic (e.g. Hermann \& Rubatto, 2009; Skora \& Blundy, 2010, 2012; Stepanov et al., 2012) or natural (Johnson \& Plank, 1999; Martindale et al., 2013) sediments. In most cases, the starting materials of these studies were doped with trace elements to facilitate trace element analysis of experimental run products and enhance the stability of accessory phases. This makes, however, direct application of experimental data to natural contexts difficult (Skora \& Blundy, 2012; Stepanov et al., 2012). Here we have deliberately used a non-doped starting material, which makes run product characterization more challenging, sometimes impossible for some elements or phases, but such an approach has the benefit of a direct correspondence with natural conditions. We have thus chosen to work with a real, low grade sediment, keeping in mind that any subducted lithology may be chemically modified during prograde metamorphism and subsequent devolatilization. It is however difficult to quantify volatiles lost from the slab. Moreover, water (and dissolved mobile elements) is reintroduced to the sediments at sub-arc depths, by dewatering of underlying subducting sediments, altered oceanic crust and serpentinite (e.g. Ulmer \& Trommsdorff, 1995; Syracuse et al., 2010; van Keken et al., 2011; Bénard et al., 2018). Our hydrous experiments $\left(8.53 \%\right.$ bounded $\mathrm{H}_{2} \mathrm{O}$ or around 15 wt. \% total $\mathrm{H}_{2} \mathrm{O}$, see below) simulate this scenario, as already explored in previous studies (e.g. Johnson \& Plank, 1999; Prouteau et al., 1999, 2001; Hermann \& Green, 2001; Klimm et al., 2008; Skora \& Blundy, 2010; Martindale et al., 2013; Prouteau \& Scaillet, 2013).

While the case for $\mathrm{H}_{2} \mathrm{O}$-rich conditions and related high $\mathrm{fO}_{2}$ in arc magmas is clear (Kelley \& Cotrell, 2009), that for S is less obvious. There is growing evidence for fluxes of sulphate in fluids during metamorphism both in and outside the subduction zone setting (e.g. 
Pons et al., 2016; Connolly \& Galvez, 2018; Walters et al., 2019, 2020). Such aqueous fluids have been described in inclusions trapped in metasomatic veins preserved in ultrahigh pressure eclogite (e.g. Sulu orogen : Zhang et al., 2008; Frezzotti \& Ferrando, 2015). Sulphate inclusions have also been identified in metasomatic garnet from the Bardane peridotite (Western Gneiss Region of Norway), which represents one of the best-known analogue for fluid-related redox processes at sub-arc depth (Rielli et al., 2017). Similarly, other studies have suggested that sulphate (anhydrite) should dominantly dissolve into metamorphic fluids released across the transition from blueschist to eclogite facies in metabasalt (e.g. Tomkins \& Evans, 2015). The $\mathrm{fO}_{2}$ of altered oceanic crust (AOC) is $\sim \mathrm{FMQ}+1$ (Foley, 2011) at the trench and decreases gradually with increasing depth (below FMQ at depths corresponding to eclogite-facies conditions, e.g. Li et al. 2016). Very few studies have focused on in situ prograde $\mathrm{fO}_{2}$ of subducted sediments. Tao et al. (2020) studied the prograde $\mathrm{fO}_{2}$ of carbonrich high pressure metamorphic rocks (marble, metapelite, eclogite) from the Western Tianshan subduction zone. In comparison with redox conditions of other subduction zones, Western Tianshan has the lowest oxygen fugacity (FMQ-1.9 to FMQ-2.5), but the studied compositions (5-20 vol \% carbonation) are different from our starting pelite. Our experiments have mostly explored moderately oxidized conditions in an attempt to replicate partial melting processes of subducted sediments under relatively high $\mathrm{fO}_{2}$ conditions, but we do not exclude that more reducing conditions could prevail in such a context. Evidence from blueschists and eclogite terrains suggests that both pyrrhotite or pyrite occur in metasediments during subduction at various metamorphic grades, though pyrrhotite is more common at higher grades (e.g Brown et al., 2014), via pyrite breakdown (e.g. Tomkins \& Evans 2015). Our experiments doped with elemental sulphur produce an assemblage saturated with rutile and pyrrhotite (see below), as often observed in exhumed high pressure metasediments. 


\section{Starting material}

Our starting material (sample B12a) is taken from the Lesser Antilles arc in the West Indies. The rock powder used for this study is an aliquot of the pelitic sediment studied by Carpentier (2007), Carpentier et al. (2008) and Prouteau \& Scaillet (2013), sampled in the Lower Scotland unity from the Barbados accretionary prism. The pelite has a mineralogy of quartz, clays (kaolinite, illite), K-feldspar, plagioclase and muscovite, in order of decreasing abundance. It is $\mathrm{CaO}$-poor $\left(\mathrm{X}_{\mathrm{Ca}}=0.05\right)$ and highly peraluminous $(\mathrm{A} / \mathrm{CNK}=3.72)$ compared to the mean composition of global oceanic sediment analogue (GLOSS-II, Table 1), representing a chemical endmember of ocean sediment composition. Carpentier et al. (2008) reported its major (Table 1) and isotopic compositions. Trace elements and volatiles $\left(\mathrm{H}_{2} \mathrm{O}, \mathrm{S}, \mathrm{Cl}, \mathrm{F}\right.$ and $\mathrm{CO}_{2}$ ) contents were obtained by inductively coupled plasma mass spectrometry (ICP-MS, CRPG, Nancy, France) (Tables 1 and 4). Sample B12a is volatile-rich with 8.53 wt. \% initial $\mathrm{H}_{2} \mathrm{O}, 1.03$ wt. $\% \mathrm{CO}_{2}, 900$ ppm S, 565 ppm Cl and 560 ppm F (Table 1; 1 ppm $=1 \mu \mathrm{g} / \mathrm{g}$ ). The ratio $\mathrm{FeO} / \mathrm{FeO}_{\text {total }}$ (potentiometric dosing, $\mathrm{CRPG}$, France) is 0.3 (Table 1), i.e. similar to commonly observed values for subducting terrigenous sediments $(\sim 0.2$; Chester, 1990). It shows a typical terrigenous sediment trace element pattern (Fig. 1), with a clear enrichment in LILE (K, Rb, Ba, Sr), a depletion in $\operatorname{HFSE}$ (e.g. $\mathrm{Nb}, \mathrm{Ta}$ ), a low $\mathrm{Ce} / \mathrm{Pb}$ ratio and highly fractionated REE.

\section{Experimental techniques}

To investigate the role of sulphur on phase relationships and compositions in the pelitic system, 1 to 2.1 wt. \% elemental sulphur was added to the powdered pelite, following the protocol of Prouteau \& Scaillet (2013). We are interested in a process whereby the sulphur is 
mainly brought to the system via the ingress of hydrous fluids released by dewatering of subducted lithologies. Indeed, using either pyrrhotite or anhydrite (as commonly practiced) as a source of $\mathrm{S}$ in experimental charges would imply that slab-derived fluids contain $\mathrm{S}$ and $\mathrm{Fe}$ (or $\mathrm{Ca}$ ) in broadly equal molar proportions, which would change the bulk composition. An additional experiment has been performed at $900^{\circ} \mathrm{C}$ using a diluted $\mathrm{H}_{2} \mathrm{SO}_{4}$ solution $(5 \mathrm{~mol} / \mathrm{L})$ as a source of fluid, following the protocol of Zajacz (2015). The $1 \mathrm{wt} . \% \mathrm{~S}_{\text {in }}$ run contains $\sim$ 15 wt. $\% \mathrm{H}_{2} \mathrm{O}$, and we add also $\sim 8$ wt. $\% \mathrm{H}_{2} \mathrm{O}$ to the $\mathrm{S}$-undoped control sample to homogenize total water content. With this experimental strategy, it can be expected that $\mathrm{S}$ is dominantly present as $\mathrm{SO}_{2}$ in any excess fluid (Binder \& Keppler, 2011; Borisova et al., 2014; Zajacz, 2015).

Powdered, hydrous (structurally bound water only) starting material was loaded into Au capsules (outer diameter: $2.0 \mathrm{~mm}$; inner diameter: $1.6 \mathrm{~mm}$; length: $10 \mathrm{~mm}$ ). On average, each experimental run contained three capsules, positioned next to each other, with 0,1 and 2.1 wt. $\% \mathrm{~S}$ added $\left(\mathrm{S}_{\mathrm{in}}\right.$, added sulphur), respectively. The pressure cell consisted of inner spacers of alumina, a graphite furnace, and an outer sleeve of talc and Pyrex. The reported pressure is nominal value. The friction coefficient for a talc-pyrex assembly is $3.6 \%$ (McDade et al., 2002). We used magnesia or boron nitride (BN) fillers (Table 2). No attempt was made to monitor $f \mathrm{O}_{2}$ during the experiments. However, our previous work carried out using the same vessel and $\mathrm{MgO}$ assemblies produced pyrrhotite + anhydrite bearing charges (Prouteau \& Scaillet, 2013), reflecting thus an intermediate $f \mathrm{O}_{2}$ range for buffer reactions involving sulphide-anhydrite-garnet-clinopyroxene. In piston cylinder experiments, the final oxygen fugacity is controlled by the initial bulk $\mathrm{Fe}^{2+} / \mathrm{Fe}^{3+}(\mathrm{FeO} / \mathrm{FeOtotal}=0.3$, Table 1$)$, $\mathrm{S}^{6+} / \Sigma \mathrm{S}$ and $\mathrm{C}^{4+} / \Sigma \mathrm{C}$ of the starting material and by the intrinsic $f \mathrm{H}_{2}$ of the furnace assembly (e.g. Holloway et al., 1992; Truckenbrodt et al., 1997; Kägi et al., 2005). In S-free systems, the intrinsic $f \mathrm{H}_{2}$ of magnesia or boron nitride-talc-Pyrex assemblies imposes redox conditions 
at or below $\mathrm{NNO}$, with $\mathrm{MgO}$ assemblies imposing more oxidizing conditions, around $\mathrm{NNO}+1$ (e.g. Kägi et al., 2005; Sisson et al., 2005; Prouteau \& Scaillet, 2013). Runs at $800^{\circ} \mathrm{C}$ and $1000^{\circ} \mathrm{C}$ were performed with $\mathrm{BN}$ assemblies and thus at an $f \mathrm{O}_{2}$ below $\mathrm{NNO}$ (in S-undoped charges), while runs at $750^{\circ} \mathrm{C}, 850^{\circ} \mathrm{C}$, and $900^{\circ} \mathrm{C}$ were done with $\mathrm{MgO}$ fillers, resulting in a $\mathrm{fO}_{2}$ above $\mathrm{NNO}$ (in S-undoped charges). The introduction of $\mathrm{S}$ will rise the $\mathrm{fO}_{2}$ by virtue of the following reaction:

$$
\mathrm{FeO}_{\text {bulk }}+\frac{1}{2} \mathrm{~S}_{2} \rightarrow \mathrm{FeS}_{\text {pyrrhotite/melt }}+\frac{1}{2} \mathrm{O}_{2}
$$

This increase in $\mathrm{fO}_{2}$ is not quantifiable, but we assume that the relative difference in $\mathrm{fO}_{2}$ imposed by the use of different assemblies remains. The assemblage pyrrhotite + rutile (see below), present in all our elemental S-doped experiments, is consistent with a large range of $\mathrm{fO}_{2}$, from $\mathrm{NNO}+1$ (provided that $\log \mathrm{fS}_{2}>\sim+2$, Supplementary Data 7) to highly reducing conditions (green area in Supplementary Data 7). As $\mathrm{fS}_{2}$ is unknown, this assemblage provides therefore few constraints on the $\mathrm{fO}_{2}$ of our experiments. The run performed with $\mathrm{H}_{2} \mathrm{SO}_{4}$, i.e. with a very high starting $\mathrm{S}^{6+} / \Sigma \mathrm{S}$, yielded higher $f \mathrm{O}_{2}(>\mathrm{NNO}+2)$, in agreement with run products characteristics (rutile + magnetite, Supplementary Data 7).

Experiments were carried out in a half-inch, end-loaded, piston-cylinder apparatus (ISTO, Orléans, France) at a nominal pressure of $3 \mathrm{GPa}$ and within the temperature range $750-1000^{\circ} \mathrm{C}$. Temperature was controlled using B-type thermocouple $\left(\mathrm{Pt}_{94} \mathrm{Rh}_{6} / \mathrm{Pt}_{70} \mathrm{Rh}_{30}\right.$; accuracy: $\pm 10^{\circ} \mathrm{C}$ ) separated from the capsules by a $0.5 \mathrm{~mm}$ thick alumina wafer. Runs lasted 4-10 days, depending on temperature. The approach toward equilibrium was checked by performing two experiments with different durations (90 to $196 \mathrm{~h}$ ) at $800^{\circ} \mathrm{C}$ (Table 2).

Experiments were quenched isobarically by adjusting the pressure during cooling. After quenching, the capsules were reweighed, showing no significant weight loss after the experiments. The entire capsules were mounted in epoxy and carefully polished with abrasive 
paper under water. Further epoxy is then added to avoid loss of the run products. The final polishing was performed with a series of diamond pastes.

\section{Analytical methods}

Run products were characterized using scanning electron microscopy (SEM, ISTO/BRGM, Orléans, France), electron microprobe (EMP, Cameca SX Five, ISTO/BRGM, Orléans) and laser-ablation inductively coupled plasma mass spectrometry (LA-ICP-MS, LMV, ClermontFerrand, France and IRAMAT/ISTO/CEMHTI, Orléans, France). Additional observation with a cathodoluminescence (CL) microscope (beam current $120 \mathrm{nA}$ during $20 \mathrm{~s}$ ) was aimed to identify $\mu \mathrm{m}$-sized accessory phases (monazite and zircon). Finally, Raman spectroscopy has led to the identification of crystallized carbonate phases $(<\mu$ size $)$ in high temperature runs (see Supplementary Data 3).

Major elements of both glasses and crystals were determined by electron microprobe with the following analytical conditions: accelerating voltage of $15 \mathrm{kV}$, sample current of $6 \mathrm{nA}$, counting time of $10 \mathrm{~s}$ on peak, with either a defocused (glass, $8 \mu \mathrm{m}$ ) or focused (crystals) beam. The measured alkali concentrations of the glasses were corrected by using secondary standards of rhyolitic compositions with known alkali and water contents (Scaillet et al., 1995). The water contents of the experimental glasses were determined by using the summation deficit to $100 \%$ of the EMP analyses method (Devine et al., 1995), with four rhyolitic standard glasses containing up to 6.4 wt. $\% \mathrm{H}_{2} \mathrm{O}$, as determined by Karl Fisher titration or ion-microprobe analysis (Scaillet et al., 1999; Martel et al., 1998). Owing to potential volatile exsolution during quench, we also estimated the amount of dissolved $\mathrm{H}_{2} \mathrm{O}$ by mass balance (Table 3). The sulphur content of the glasses was determined using an accelerating voltage of $15 \mathrm{kV}$, a current of $50 \mathrm{nA}$, counting time of $60 \mathrm{~s}$ and a defocused beam 
of $10 \mu \mathrm{m}$. We used three S-bearing dacitic glass standards with sulphur contents determined by wet chemistry (Clemente et al., 2004). Pyrrhotites were analysed for four experiments (900 and $1000^{\circ} \mathrm{C} ; 1$ and 2.1 wt. $\left.\% \mathrm{~S}_{\text {in }}\right)$ with a focused beam $(20 \mathrm{kV}, 20 \mathrm{nA})$ and a counting time of 30 seconds for each element (S, Fe).

Wherever possible owing to the phase sizes, trace element contents of glasses and minerals were obtained by laser-ablation ICP-MS. The concentrations of alkalis ( $\mathrm{Li}, \mathrm{Rb})$, alkaline earth (Be, Sr, Ba), lanthanides (La, Ce, Nd, Sm, Eu, Dy, Yb), Y, actinides (Th, U), $\mathrm{Pb}, \operatorname{HFSE}(\mathrm{Nb}, \mathrm{Ta}, \mathrm{Zr}, \mathrm{Hf})$ and $\mathrm{B}$ of glasses and silicate minerals were determined using a pulsed 193 nm EXCIMER laser (Resonetics M-50E) coupled to an Agilent 7500 ICP-MS (LMV, Clermont-Ferrand, France). Additional analyses of $\mathrm{Pb}$ in glasses and sulphides were carried out with a pulsed $193 \mathrm{~nm}$ EXCIMER laser coupled to a Thermo Element XR ICP-MS (IRAMAT/ISTO/CEMHTI, Orléans, France). The following settings were used: a $2.8 \mathrm{~J} . \mathrm{cm}^{-2}$ fluence at a repetition rate of $2 \mathrm{~Hz}$ and a spot size of 20-26 $\mu \mathrm{m}$ for glasses, $15-20 \mu \mathrm{m}$ for silicate minerals and 11-15 $\mu \mathrm{m}$ for sulphides. For each analysis, data were collected for a total time of 90 seconds, including gas (argon) background of 25 seconds. The synthetic glass NIST 610 was used for external calibration for silicate phases and MASS-1 for sulphides. NIST 612 and a BCR-2G glasses (Jochum et al., 2005; Jacob, 2006) were used as secondary standards and the measured compositions are given in Supplementary Data 6. For silicate phases, we used concentration of aluminium $\left({ }^{27} \mathrm{Al}\right)$ as internal standard. To determine the partitioning of $\mathrm{Pb}$ between sulphides and silicate glasses, the concentration of iron $\left({ }^{57} \mathrm{Fe}\right)$ was used as an internal standard. Data were reduced using the GLITTER software and mineral inclusions were excluded via inspection of a count-rate versus time diagram. The average analytical standard error ( 1 sigma) was $<5 \%$ for most trace elements except for $\mathrm{Hf}(\sim 7 \%)$, $\mathrm{Yb}$ and $\mathrm{Ta}(\sim 10 \%), \mathrm{Be}(\sim 18 \%)$ and $\mathrm{B}(\sim 24 \%)$. 
Finally, micro-Raman spectra (Supplementary Data 3) were acquired on a Horiba JobinYvon LabRam@ HR800 Evolution spectrometer (Laboratoire de Planétologie et de Géodynamique, Nantes, France). The spectrometer is equipped with a solid-state laser diode operating at $532 \mathrm{~nm}$ and with a 1800 grooves/mm grating allowing a spectral resolution on the order of $\sim 0.4 \mathrm{~cm}^{-1}$. Analyses were performed in confocal mode (hole $=75 \mu \mathrm{m}$ ) using a x100 Olympus objective. The studied spectral range was between 300 and $1250 \mathrm{~cm}-1$, covering the area of the silicate network. The spectral frequency position was calibrated using the emission lines of $\mathrm{Ne}$ - and Hg-lamps. The acquisition time of a given sample was typically between 5 and $10 \mathrm{~s}$ and $10 \mathrm{scans}$ were accumulated. The output power was set to $100 \mathrm{~mW}$.

\section{EXPERIMENTAL RESULTS}

Details of experimental conditions and run products are listed in Table 2 and illustrated in Fig. 2.

\section{Time series experiment at $800^{\circ} \mathrm{C}$}

After 90 hours, silicate melt coexists with staurolite + quartz + biotite \pm garnet $\left(0\right.$ wt. $\left.\% \mathrm{~S}_{\text {in }}\right)+$ rutile + pyrrhotite. The proportion of biotite (phlogopite sensu stricto, see below) increases with increasing $\mathrm{S}_{\mathrm{in}}$. Phengite is systematically absent in these short run duration experiments, regardless $S_{\text {in }}$ (Table 2). Garnet is present only in the S-undoped charge. Fe-staurolite is abundant (24-26 wt. \%, whatever the bulk sulphur content), being present across the entire length of the charges as microcrystals (mean length $=2-3 \mu \mathrm{m}$; Fig. $2 \mathrm{~b}$ ).

After 196 hours, biotite is observed only in S-doped experiments ( 1 and $\left.2.1 \mathrm{wt} . \% \mathrm{~S}_{\text {in }}\right)$ as large $(80-90 \mu \mathrm{m})$ euhedral crystals (Fig. $2 \mathrm{~d})$ and its proportion increases with $\mathrm{S}_{\text {in }}$ (Table 2). In contrast, phengite is present only in the S-undoped charge. Kyanite is the main aluminium 
silicate phase (Figs 2c, 2d) and staurolite is present only in trace amounts. Garnet is identified in all charges in these long run duration experiments and its mode decreases with $\mathrm{S}_{\text {in }}$ (Table 2).

The main effects of an increase of run duration, at fixed S content, are therefore summarized as follows (Table 2): for the sulphur-undoped runs, longer duration promotes the crystallization of phengite whereas biotite is not stable anymore. The recent experimental study of Pichavant et al. (2016) shows that at low $\mathrm{fO}_{2}$ ( NNO-1.6 to -1.4) biotite is the stable mica in peraluminous melts, whereas at high $f \mathrm{O}_{2}(\mathrm{NNO}+1$ to +3$)$ it is replaced by muscovite. On this basis, we suggest that the observed phengite to biotite phase change reflects a higher $f \mathrm{O}_{2}$ in 196 hours run duration experiment (through $\mathrm{H}_{2}$-mediated redox reactions). In sulphurdoped experiments, phengite is never stable (see later) and the proportion of biotite systematically increases with increasing run duration (from 3.4 to $6.6 \mathrm{wt} \% \%$ for $1 \mathrm{wt} . \% \mathrm{~S}_{\text {in }}$ and from 4.9 to 10.6 wt. $\%$ for 2.1 wt. $\% \mathrm{~S}_{\text {in }}$, Table 2 ).

Nucleation and growth of garnet is promoted in long run duration experiments (Table 2). In contrast, staurolite is replaced by kyanite or kyanite + garnet in long duration runs. This observation is consistent with recent experimental studies, which suggest that staurolite nucleates metastably at high pressure (3 GPa) in sedimentary (Skora \& Blundy, 2010) or basaltic (Carter et al., 2015) systems. Pioneer studies on the stability of staurolite in pelitic system have suggested indeed that almandine+kyanite is stable relative to Fe-rich staurolite at eclogite-facies conditions (e.g. Richardson, 1968; Ganguly, 1972; Ballèvre et al., 1989). Staurolite presence is not consistent with natural phase assemblages or thermodynamic grids of high-pressure, low-temperature metapelites (e.g. Yardley, 1977; Powell \& Holland, 1990, Wei \& Powell, 2003; Smye et al., 2010) or other experimental studies (e.g. Johnson \& Plank, 1999; Hermann \& Spandler, 2008). 
We thus conclude that staurolite is metastable relative to garnet and kyanite, and that long run durations are necessary to reach steady state in the lower temperature range. Based on these tests, we favor the long run duration experiments for $800^{\circ} \mathrm{C}$ and only their results will be presented and discussed in the following sections. Below $900^{\circ} \mathrm{C}$, the melting experiments performed were generally held at pressure and temperature for more than 7 days. However, at $750^{\circ} \mathrm{C}$, despite a long run duration $(>10$ days), staurolite remains the main alumino-silicate phase (kyanite is only identified in trace amounts at $2.1 \mathrm{wt} . \% \mathrm{~S}_{\text {in }}$, see Table 2 and Figs $2 \mathrm{a}, 3$, 4). The increase in run durations could lead to the dessication of the charge, following a drastic loss of $\mathrm{H}_{2}$ through the sleeve and, therefore, could induce a significant change of $f \mathrm{O}_{2}$ and $\mathrm{H}_{2} \mathrm{O}$ content during the experiment. If at $750^{\circ} \mathrm{C}$ staurolite is also metastable, then experiments at $800^{\circ} \mathrm{C}$ suggest that it should be replaced by kyanite and garnet. While the former phase has no practical consequence on trace element behaviour, the same is not true for garnet. The interpretation of analytical results discussed below should therefore bear in mind that garnet proportions in the $750^{\circ} \mathrm{C}$ charges are probably minimum values.

\section{General observations}

Inter-experiment variation as a function of run conditions are consistent, considering the wide range of variables in our experiments. No systematic variations in most mineral or melt compositions (within analytical error) were found across the length of experimental charges. Limited mineral zoning was identified only in garnet, especially at low temperature (Supplementary Data 1). Most crystals are euhedral except some xenomorphic quartz at the bottom end of capsule at or below $800^{\circ} \mathrm{C}$. No mineral quench phases have been observed within experimentally produced glass. Hydrous silicate glass (quench liquid) is present in all experimental charges. Glass occurs evenly throughout charges, although some local 
concentrations are apparent near the tip of the capsule. At $750{ }^{\circ} \mathrm{C}$ and, to a lesser extent, $800^{\circ} \mathrm{C}$, charges show two spatially segregated regions of phase crystallization, with a region dominated by phengite ( \pm biotite) and quartz, while the others, near the tip of the capsules, consist generally of garnet ( \pm kyanite) and hydrous, vesiculated glass. These phase segregations, already observed in previous studies (e.g. Schmidt \& Ulmer, 2004; Li \& Hermann, 2015), could represent the segregation of reactants and products during melting. Small, micron-sized vesicles, free of crystal inclusions, occur in quenched glasses of low temperature experiments $\left(\leq 850^{\circ} \mathrm{C}\right)$. The abundance of vesicles decreases with increasing temperature (Figs 2a, 2c, 2e). We interpret these as resulting from fluid exsolution upon quench. At 900 and $1000^{\circ} \mathrm{C}$, the glass displays a clean texture, free of any bubbles, supporting the idea that our run products have been cooled at a rate fast enough to avoid large quench effects (e.g. Hermann \& Spandler, 2008). Therefore we propose that the pelite experiments with 8.5 wt. \% structurally bound $\mathrm{H}_{2} \mathrm{O}$ are water-undersaturated and fully quenchable to a glass. For the two experiments with added $\mathrm{H}_{2} \mathrm{O}$ or $\mathrm{H}_{2} \mathrm{SO}_{4}$, PEL68h and PEL69h respectively (Table 2), run products show a vesicular glassy matrix with, in addition to micron-sized vesicles, a population of larger vesicles probably arising from vapoursaturated conditions at high P-T conditions. Phase segregations (quartz + minor staurolite) have been observed near the tip of the PEL69h capsule.

Charges are dominated by the assemblage kyanite \pm garnet \pm quartz \pm phengite and/or biotite \pm orthopyroxene and peraluminous to metaluminous granitic melts (Table 2, Fig. 2). Identified minor phases include rutile, Ti-magnetite, monazite, zircon, pyrrhotite and submicron-sized Cl-rich and carbonated phases. As stated in the previous section, microcrystals $(<5 \mu \mathrm{m})$ of staurolite persist at $750^{\circ} \mathrm{C}$ and, to a lesser extent, $800^{\circ} \mathrm{C}$, either as isolated phases or as inclusion in quartz and micas, from major to trace amounts, instead of, or together with, kyanite. 
For experiments performed at or above $850^{\circ} \mathrm{C}$, a crystalline, micron-sized $(<5 \mu \mathrm{m})$ Cl-rich phase has been identified (Supplementary Data 3). Semi-quantitative analysis (Energy dispersive X-ray mapping analysis; detector EDS QUANTAX, ISTO) shows that this phase is $\mathrm{Na}_{2} \mathrm{O}-\left(\sim 35\right.$ wt. $\%$ at $\left.900^{\circ} \mathrm{C}\right)$ and Cl-rich $(\sim 40$ wt. $\%)$ with some $\mathrm{K}_{2} \mathrm{O}$ and traces of $\mathrm{Al}_{2} \mathrm{O}_{3}$, $\mathrm{SiO}_{2}, \mathrm{CaO}$ and $\mathrm{MgO}$. We interpret the $\mathrm{Cl}$ bearing phase as (minor) quench product, since the bulk $\mathrm{Cl}$ content of the starting material $(565 \mathrm{ppm})$ is well below brine saturation values of common silicate melts (Webster et al., 2015) and the applied pressure is well above the crest of the $\mathrm{H}_{2} \mathrm{O}-\mathrm{NaCl}$ solvus in a $\mathrm{P}-\mathrm{X}_{\mathrm{NaCl}-\mathrm{H}_{2} \mathrm{O}}$ projection (ca $0.2 \mathrm{GPa}$ ). Submicron-size carbonated phases have been unambiguously identified by Raman spectroscopy (Supplementary Data 3) above $850^{\circ} \mathrm{C}$ (Table 2$)$.

\section{Phase proportions}

Details on run products and phase proportions, calculated by mass balance (Albarède, 1995), are listed in Table 2 and illustrated in Fig. 3. Isobaric phase relations are reported as a function of $\mathrm{S}$ addition $\left(\mathrm{S}_{\mathrm{in}}\right)$ in Fig. 4. Phase boundaries (Fig. 4) are drawn for melting experiments doped with elemental $\mathrm{S}$, with $\mathrm{BN}$ or $\mathrm{MgO}$ fillers. Despite the range of $f \mathrm{O}_{2}$ induced by these various assemblies, a consistent picture emerges in Figs 3 and 4.

\section{Effect of temperature at fixed $S_{\text {in }}$}

For sulphur-undoped experiments $\left(8.53\right.$ wt. \% bound $\left.\mathrm{H}_{2} \mathrm{O}\right)$, glass is the most abundant phase. Melt proportion increases abruptly with temperature until $850{ }^{\circ} \mathrm{C}$ and more gently beyond this temperature. At $750^{\circ} \mathrm{C}$, staurolite $(<5 \mu \mathrm{m})$ is abundant $(19 \mathrm{wt} . \%)$ and probably metastable as discussed above. Phengite makes up $>20 \%$ of the charge at $750^{\circ} \mathrm{C}$, appearing as euhedral to 
sub-euhedral $(10-20 \mu \mathrm{m})$ crystals heterogeneously dispersed in the charge (Fig. 3). At $800^{\circ} \mathrm{C}$, its abundance decreases to a few percent. Biotite is not stable in the conditions investigated. Garnet has a euhedral shape, with a grain size increasing from $\sim 15 \mu \mathrm{m}$ at $750^{\circ} \mathrm{C}$ to $\sim 45 \mu \mathrm{m}$ at $1000^{\circ} \mathrm{C}$. Micron-sized inclusions in garnet are sporadic (kyanite, rutile, and pyrrhotite). Garnet abundance increases up to $850^{\circ} \mathrm{C}$ and then decreases significantly (Fig. 3). The proportion of kyanite is roughly constant in the studied melting interval. Quartz abundance decreases sharply until $850^{\circ} \mathrm{C}$; at $900^{\circ} \mathrm{C}$, only trace amounts of $\mathrm{SiO}_{2}$ are detected. Finally, charges are saturated in rutile, whose size increases with temperature. They are saturated in pyrrhotite in the entire melting interval, and with monazite and zircon at $750-800^{\circ} \mathrm{C}$. Experiment PEL68h, performed at $900^{\circ} \mathrm{C}$ with $\sim 15$ wt. $\%$ total $\mathrm{H}_{2} \mathrm{O}$ yielded the same run products as PEL9 $\left(900{ }^{\circ} \mathrm{C}, 8.53\right.$ wt. $\%$ bound $\mathrm{H}_{2} \mathrm{O}$ ), lacking pyrrhotite (Table 2).

For the elemental S-doped pelite, at fixed $\mathrm{S}_{\text {in }}(1 \mathrm{wt} \%$ and $2.1 \mathrm{wt} \%$ ), melt, garnet and quartz exhibit the same behaviour as observed in S-undoped charges with increasing temperature: melt proportion increases abruptly with temperature until $850^{\circ} \mathrm{C}$ and more gently beyond (Fig. 3); garnet proportion increases from 750 to $850^{\circ} \mathrm{C}$ and then decreases from 850 to $1000^{\circ} \mathrm{C}$. Quartz abundance decreases sharply until $850^{\circ} \mathrm{C}$. Modal kyanite decreases slightly with increasing temperature at fixed S content. Phengite is not stable beyond $750^{\circ} \mathrm{C}$. Modal biotite increases in the $750-800^{\circ} \mathrm{C}$ interval and is not stable at higher temperature. Biotite forms euhedral grains ranging from a few microns up to $90 \mu \mathrm{m}$ for the higher temperature charges. Orthopyroxene trend is less clear, but its proportion decreases with increasing temperature (Table 2). The proportion of pyrrhotite increases from 750 to $800^{\circ} \mathrm{C}$, and then appears weakly correlated with temperature (Table 2 ). The proportion of pyrrhotite reaches 45 wt. $\%$ in the less oxidizing charges $\left(800\right.$ and $\left.1000^{\circ} \mathrm{C}\right)$, with $\mathrm{S}_{\text {in }}=2.1$ wt. \%. (Table 2).

The $\mathrm{H}_{2} \mathrm{SO}_{4}$ doped experiment PEL69h, performed at $900^{\circ} \mathrm{C}$ with $\sim 15$ wt. $\%$ total $\mathrm{H}_{2} \mathrm{O}$ $\left(1 \mathrm{wt} . \% \mathrm{~S}_{\text {in }}\right)$, is saturated with both garnet and kyanite and yielded roughly the same run 
products as PEL13 (Table 2). Mass balance indicates $\sim 1 \mathrm{wt} . \%$ of titanomagnetite, whereas only a few crystals of rutile, systematically included in titanomagnetite, have been detected (0.4 wt. \%). Pyrrhotite is only present in trace amount. Quartz segregations, isolated at the base of the capsule, are excluded from the mass balance calculation. This calculation yields high residual and suggests the presence of a Ca-bearing phase (anhydrite) which might have gone undetected in the run product (or removed during polishing). The higher standard deviation of $\mathrm{SiO}_{2}$ indicates that the glass in PEL69h is less homogeneous in major elements than all other charges, hence mass balance constraints are less reliable.

\section{Effect of $S_{\text {in }}$ at fixed temperature}

At fixed $\mathrm{T}$, adding elemental $\mathrm{S}$ at a percent level has a profound effect on phase relationships (Figs 3, 4). Biotite, not stable in S-undoped runs, crystallizes together with $\left(750^{\circ} \mathrm{C}\right)$, or in lieu of $\left(800^{\circ} \mathrm{C}\right)$, phengite, and its modal abundance increases with $\mathrm{S}_{\text {in }}$ (Figs 3a, 3b, 4). Conversely, phengite mode decreases with $S_{\text {in }}$ (Figs 3a, 3b). The proportion of kyanite (or staurolite at $750^{\circ} \mathrm{C}$ ) increases with $\mathrm{S}_{\mathrm{in}}$, at fixed $\mathrm{T}$, together with that of quartz below $900^{\circ} \mathrm{C}$ (except at $750^{\circ} \mathrm{C}$ between 0 and 1 wt. $\% \mathrm{~S}_{\text {in }}$ ). Garnet proportion strongly decreases with increasing sulphur content. In 2.1 wt. $\% \mathrm{~S}_{\text {in }}$ charges, only a few crystals are detected at low $\mathrm{T}$ and garnet is not stable beyond $850^{\circ} \mathrm{C}$. Garnet size increases with $\mathrm{S}_{\text {in }}$, while kyanite size decreases. Orthopyroxene crystallizes together with $\left(850^{\circ} \mathrm{C}\right)$, or instead of $\left(900^{\circ} \mathrm{C}\right)$, garnet in the $2.1 \mathrm{wt}$. $\% \mathrm{~S}_{\text {in }}$ charges. At fixed $\mathrm{T}$, the modal abundance of pyrrhotite increases markedly with sulphur content (Table 2).

At $750^{\circ} \mathrm{C}$, the proportion of melt, saturated with phengite, increases with S content. An opposite effect is observed at $800^{\circ} \mathrm{C}$, in the stability field of biotite. At $\mathrm{T} \geq 850^{\circ} \mathrm{C}$, melt 
proportion increases slightly with sulphur content (e.g. from $68 \mathrm{wt} . \%\left(0 \mathrm{wt} . \% \mathrm{~S}_{\text {in }}\right)$ to $73 \mathrm{wt}$. $\%\left(2.1\right.$ wt. $\left.\% \mathrm{~S}_{\text {in }}\right)$ at $900{ }^{\circ} \mathrm{C}$; Table 2 and Fig. 3).

\section{PHASE COMPOSITIONS}

\section{Major element chemistry}

Major element compositions of hydrous silicate melts are listed in Table 3. Major element compositions of minerals are given in Supplementary Data 1. Short run duration experiments at $800^{\circ} \mathrm{C}$ are not presented. Experimental glasses and silicate minerals are relatively homogeneous, with standard deviations $(\sigma)<10 \%$ relative, with the exception of zoned garnet. Phase compositions are controlled predominantly by temperature, $\mathrm{H}_{2} \mathrm{O}$ and bulk sulphur contents. In spite of differences in oxygen fugacity for experiments doped in elementary sulphur performed at $750 / 850 / 900^{\circ} \mathrm{C}$ (magnesia filler) and $800 / 1000^{\circ} \mathrm{C}(\mathrm{BN}$ filler), this has no detectable effect on major element chemistry.

\section{Garnet}

Garnet is present in all experimental charges except those doped with $2.1 \mathrm{wt.} \% \mathrm{~S}_{\text {in }}$ at 900 and $1000^{\circ} \mathrm{C}$. Zoned garnet cores are characterized by higher Ti, Fe, Mn (p.f.u.) and lower $\mathrm{Mg}$ and Ca contents than in the rim (Supplementary Data 1). The following discussion is based on rim compositions, which are interpreted to be in equilibrium with other phases. Garnets have high pyrope (30-56 \%) and almandine (36-60\%) contents with significant grossular (0.7 to $10 \%)$ whereas spessartine remains low (0.3 to $5 \%)$. They are characterized by low Ca contents ( 0.02 to 0.28 , pfu; Fig. $5 \mathrm{c})$ compared to high pressure synthetic garnet produced in previous 
experiments in pelitic system (e.g. Hermann \& Spandler, 2008), reflecting the very low calcium content of our starting composition. Garnet trends reflect high-pressure equilibrium and show systematic changes with temperature and/or S contents.

The most significant feature is an increase of pyrope content and $X_{\mathrm{Mg}}\left(\mathrm{X}_{\mathrm{Mg}}=\mathrm{Mg} /\left(\mathrm{Fe}_{\mathrm{T}}\right.\right.$ $+\mathrm{Mg}$ ), in moles), and a decrease in $\mathrm{Ca}$ and grossular contents with increasing temperature, for a given $S_{\text {in }}($ Figs 5a, 5b, 5c). Ti (p.f.u.) and $\mathrm{Al}$ (p.f.u.) values increase between 750 and 850 ${ }^{\circ} \mathrm{C}$, in the stability field of phengite, and then decrease beyond $850^{\circ} \mathrm{C}$. Si (p.f.u.) contents slightly increase with temperature.

With increasing $\mathrm{H}_{2} \mathrm{O}_{\text {in }}$ (at fixed $\mathrm{T}$ and $\mathrm{S}_{\text {in }}$; Supplementary Data 1), Fe (p.f.u.) contents strongly increase while $\mathrm{Si}$ and $\mathrm{Al}$ (p.f.u.) contents decrease, together with $\mathrm{X}_{\mathrm{Mg}}$ (Fig. 5b). At fixed $\mathrm{T}$ and $\mathrm{H}_{2} \mathrm{O}_{\text {in }}$, the $\mathrm{X}_{\mathrm{Mg}}$ increases drastically with the sulphur content: e.g. from 0.37 in a sulphur-undoped system at $850^{\circ} \mathrm{C}$ to 0.59 with 2.1 wt. $\% \mathrm{~S}_{\text {in }}$ (Fig. $5 \mathrm{~b}$ ). Pyrope, grossular and spessartine components increase with the addition of elemental sulphur, at fixed temperature, whereas almandine component decreases (Figs 5a, 5c). This trend is less clear for the experiment doped with $\mathrm{H}_{2} \mathrm{SO}_{4}$ (Fig. 5a).

\section{Orthopyroxene}

Orthopyroxene is present only in two charges with $2.1 \mathrm{wt} . \% \mathrm{~S}_{\text {in }}$ at 850 and $900^{\circ} \mathrm{C}$. It is an enstatite with composition $\mathrm{En}_{76-77} \mathrm{Fe}_{23-24}$ (Supplementary Data 1). The wollastonite component does not exceed $0.2 \%$. Orthopyroxene is characterized by high $\mathrm{Al}_{2} \mathrm{O}_{3}$ contents $(\sim$ 8-9 wt. $\left.\% \mathrm{Al}_{2} \mathrm{O}_{3}\right)$ and $\mathrm{X}_{\mathrm{Mg}}(\sim 0.77)$. The composition shows no significant variation with varying temperature (Supplementary Data 1). 


\section{Phengite}

Only the $750^{\circ} \mathrm{C}$ and the sulphur-undoped $800^{\circ} \mathrm{C}$ experiments crystallized phengite. Phengite is aluminous (26-30 wt. \%) and $\mathrm{Na}_{2} \mathrm{O}$ rich (8-9 wt. \%) (Supplementary Data 1 ). $\mathrm{TiO}_{2}$ content is low $(<1.2$ wt. \%) and increases with increasing temperature in S-undoped experiments. Structural formulae, calculated on the basis of $11 \mathrm{O}$, yield Si (p.f.u.) above 3.2. The Si content decreases with increasing temperature for S-undoped charges (Fig. 6a). Both Ti and Si (p.f.u.) trends with temperature are consistent with experiments in chemically comparable systems (e.g. Hermann \& Spandler, 2008). At $750{ }^{\circ} \mathrm{C}$, Si content increases with sulphur addition (Fig. 6a). All phengites contain $\mathrm{Mg}+\mathrm{Fe}>\mathrm{Si}-3$ (p.f.u.), indicating that there is a biotite component present, which increases with T for S-undoped charges. With increasing temperature, Fe, Mn and $\mathrm{Mg}$ (p.f.u.) contents and $\mathrm{X}_{\mathrm{Mg}}$ increase while $\mathrm{Na}$ and $\mathrm{Al}$ (p.f.u.) contents decrease. At $750^{\circ} \mathrm{C}, \mathrm{Mg}$ (p.f.u.) content increases and $\mathrm{Al}$ (p.f.u.) content decreases. At $750^{\circ} \mathrm{C}, \mathrm{X}_{\mathrm{Mg}}$ is significantly higher for the 2.1 wt. $\% \mathrm{~S}_{\text {in }}$ charge (Fig. 6c).

\section{Biotite}

Biotite (sensu lato) is present at 750 and $800^{\circ} \mathrm{C}$ in the most sulphur-rich charges ( 1 and 2.1 wt. $\left.\% \mathrm{~S}_{\text {in }}\right)$. At fixed $\mathrm{S}$, the $\mathrm{TiO}_{2}$ contents (1.4-2 wt. \%, Supplementary Data 1) increases with temperature together with $\mathrm{MgO}$, whereas the $\mathrm{FeO}$ and $\mathrm{Na}_{2} \mathrm{O}$ contents decrease. Biotite is aluminous (18.2-20.7 wt. \% $\left.\mathrm{Al}_{2} \mathrm{O}_{3}\right)$ with high $\mathrm{MgO}$ contents (13-16 wt. \%). Biotite is a phlogopite (sensu stricto) following the division of Deer et al. (1962) : it is characterized by relatively high $\mathrm{X}_{\mathrm{Mg}}(0.69-0.82$; Fig. $6 \mathrm{~d})$, which compares well with the $\mathrm{X}_{\mathrm{Mg}}$ range of biotite produced in sulphur-free experiments in similar systems (e.g. biotite $\mathrm{X}_{\mathrm{Mg}}$ between 0.71 and 0.78 at $2.5 \mathrm{GPa}, 750-900^{\circ} \mathrm{C}$, Hermann $\&$ Spandler, 2008; Fig. 6d). For a given temperature, 
$\mathrm{X}_{\mathrm{Mg}}$ increases strongly with sulphur addition. $\mathrm{X}_{\mathrm{Mg}}$ increases with temperature, for a given $\mathrm{S}_{\mathrm{in}}$. With 1 wt. \% sulphur added, this effect is, however, less clear (Fig. 6d).

\section{Other phases}

Staurolite occurs as small grains $(<5 \mu \mathrm{m})$ in all $750^{\circ} \mathrm{C}$ charges and in the short run duration experiment performed at $800{ }^{\circ} \mathrm{C}$ (Table 2). Because of the small grain size, microprobe analysis was difficult. We have successfully analysed Fe-rich staurolite produced at $900^{\circ} \mathrm{C}$ in $\mathrm{H}_{2} \mathrm{O}$-doped experiments (Supplementary Data 1).

At low temperature $\left(<900^{\circ} \mathrm{C}\right)$, the small size of sulphide (whatever the sulphur content), an ubiquitous minor phase, prevents its accurate chemical characterization. Sulphides produced at 900 and $1000^{\circ} \mathrm{C}$ are pyrrhotite with $\mathrm{FeO}$ contents of $57-58$ wt. \% and $\mathrm{S}$ contents of 40.5-41.7 wt. \% (Supplementary Data 1).

Monazite, ubiquitous at 750 and $800^{\circ} \mathrm{C}$, is Ce-rich and may incorporate some sulphur in S-doped experiments, according to chemical mapping (Supplementary Data 3).

\section{Glass}

Table 3 presents the glass analyses normalized to $100 \%$ on an anhydrous basis. The water contents of the quenched glasses estimated by the by-difference method fall in the range 6.714 wt. \% (Table 3), and increase roughly with temperature. The presence of micron-sized bubbles in the lowest temperature charges $\left(\leq 850^{\circ} \mathrm{C}\right)$ or in those $\mathrm{H}_{2} \mathrm{O}$-doped suggests, however, that such estimates are minima. In the $750-850^{\circ} \mathrm{C}$ temperature interval, the full range of mass-balance estimates of dissolved $\mathrm{H}_{2} \mathrm{O}$ is $13-36$ wt. \%, the highest content (at $750^{\circ} \mathrm{C}$ ) being close to the $\mathrm{H}_{2} \mathrm{O}$ solubility determined at $4 \mathrm{GPa}$ (Kessel et al., 2005b). These 
values are in some cases considerably higher than that given by the by-difference method, especially at low temperatures (e.g. at $750{ }^{\circ} \mathrm{C}, \mathrm{S}$-undoped: by-difference $=7.2 \mathrm{wt} . \%$; massbalance $=36.4$ wt. $\%$, Table 3), corroborating the fact that some water may have been exsolved during quenching. The same feature is observed for the $\mathrm{H}_{2} \mathrm{O}$ or $\mathrm{H}_{2} \mathrm{O}+\mathrm{H}_{2} \mathrm{SO}_{4}$ doped charges (Table 3). In contrast, for the S-undoped or elemental sulphur-doped experiments performed at 900 and $1000^{\circ} \mathrm{C}$, melt water contents determined by the two methods fall within the same range (11.4-14 wt. \%), suggesting few if any quenched effects for these experimental conditions.

Experimental glasses have silicic compositions $\left(\mathrm{SiO}_{2}\right.$ contents between 74 and 79 wt. $\%$, on an anhydrous basis), becoming increasingly peraluminous (molar $\mathrm{Al}>\mathrm{Na}+\mathrm{K}+2 \mathrm{Ca}$ ) with temperature, all charges defining a single common trend (Fig. $7 \mathrm{a})$. At $750^{\circ} \mathrm{C}$, the S-undoped charge produces a metaluminous glass with an aluminium saturation index $(\mathrm{ASI}$ or $\mathrm{A} / \mathrm{CNK}=$ $\mathrm{Al} / \mathrm{Na}+\mathrm{K}+2 \mathrm{Ca}$ ) of $\sim 0.94$ while glasses in S-doped charges are peraluminous (Fig. 7a, Table 3). The $\mathrm{TiO}_{2}$ contents are $<1 \mathrm{wt} . \%$, increasing steadily from 750 to $1000^{\circ} \mathrm{C}$, reflecting enhanced rutile solubilities at higher temperatures (Table 3, Fig. 7b) (e.g. Ryerson \& Watson, 1987; Klimm et al., 2008). Similarly, both $\mathrm{FeO}$ and $\mathrm{MgO}$ contents increase with increasing temperature, with $\mathrm{X}_{\mathrm{Mg}}$ in the range 0.36-0.67. At a fixed temperature, $\mathrm{FeO}$ decreases whereas $\mathrm{MgO}$ increases with the addition of elemental sulphur (Table 3). Therefore, $\mathrm{X}_{\mathrm{Mg}}$ decreases with increasing temperature at a fixed $\mathrm{S}_{\text {in }}$, but this trend is reversed for the most $\mathrm{S}$-doped charges, especially beyond the stability field of garnet (Fig. 7c). In contrast, $X_{M g}$ increases strongly with the addition of sulphur at a fixed temperature (Fig. 7c).

The $\mathrm{CaO}$ content is uniformly low, $<1.5 \mathrm{wt} . \%$ (Table 3 ), decreasing weakly with increasing temperature and increasing with sulphur content (Table 3). The $\mathrm{K}_{2} \mathrm{O}$ content ranges between $\sim 2$ and 4 wt. \% (Fig. 7e). With increasing T, first $\mathrm{K}_{2} \mathrm{O}$ increases, peaking at $\mathrm{T} \sim$ $800^{\circ} \mathrm{C}$, (Fig. 7e), then decreases. The first part reflects the progressive consumption of micas, 
while the second part a simple dilution effect once micas are exhausted. $\mathrm{Na}_{2} \mathrm{O}$ decreases sharply with increasing temperature and, though less clearly, with $S_{\text {in }}$ (Fig. 7d). Consequently, the low temperature glasses are characterized by $\mathrm{K}_{2} \mathrm{O} / \mathrm{Na}_{2} \mathrm{O}$ ratios lower than that of the starting composition (Fig. 7f). With increasing temperature, the ratio $\mathrm{K}_{2} \mathrm{O} / \mathrm{Na}_{2} \mathrm{O}$ increases. At fixed $\mathrm{T}$ above $850^{\circ} \mathrm{C}, \mathrm{Na}_{2} \mathrm{O}$ and $\mathrm{K}_{2} \mathrm{O} / \mathrm{Na}_{2} \mathrm{O}$ ratios increase with the addition of elemental sulphur (Table 3, Fig. 7f). The glass produced at $900^{\circ} \mathrm{C}$ with 15 wt. $\% \mathrm{H}_{2} \mathrm{O}$ and 1 wt. $\% \mathrm{~S}_{\text {in }}$ has a significantly higher $\mathrm{Na}_{2} \mathrm{O}$ content than the $\mathrm{H}_{2} \mathrm{O}$-undoped experiments performed at the same $\mathrm{P}-\mathrm{T} / \mathrm{S}_{\text {in }}$ conditions (Fig. $\left.7 \mathrm{~d}\right)$.

In the Ab-An-Or diagram (Fig. 7g), melt compositions have low anorthite contents, a reflection of their low Ca contents, and trend away from the trondhjemite field towards the granite field as temperature increases, as observed for sulphur-free synthetic pelitic compositions at $>2.5 \mathrm{GPa}$ (e.g. Hermann \& Spandler, 2008). At $750^{\circ} \mathrm{C}$, increasing sulphur content in the system increases the normative An content (Fig. 7g), while at higher T S-free and S-bearing charges define a single common trend.

\section{Melt sulphur contents}

All charges are pyrrhotite-saturated, except PEL68h (15 wt. \% $\mathrm{H}_{2} \mathrm{O}, 900$ ppm S). Anhydrite, in addition of pyrrhotite, is suspected in experiment PEL69h (doped with $\mathrm{H}_{2} \mathrm{SO}_{4}$ ) but not demonstrated unequivocally.

The S contents in experimental glasses range from 72 to 3507 ppm (Table 3), increasing gently with temperature, other parameters being equal (Fig. 8a), as observed in previous studies (e.g. Carroll \& Rutherford, 1987; Luhr, 1990). At fixed T, melt sulphur content increases with $\mathrm{S}_{\text {in }}$ for a given filler and protocol (elemental $\mathrm{S}$ or $\mathrm{H}_{2} \mathrm{SO}_{4}$ addition) (Table 3, Figs $8 \mathrm{a}, 8 \mathrm{~b}) .$. At $1000^{\circ} \mathrm{C}$, this effect is, however, barely detectable and melt sulphur 
contents are uniformly low ( $220-260$ ppm, Table 3, Fig. 8a). The glass in the charge PEL69h synthesized at $3 \mathrm{GPa}$ and $900^{\circ} \mathrm{C}$, with 1 wt. $\% \mathrm{~S}$ added as $\mathrm{H}_{2} \mathrm{SO}_{4}$, has a sulphur content of $\sim 3507$ ppm (Fig. 8b), which is four times higher than that annealed with 1 wt. $\%$ elemental sulphur ( $\sim 850 \mathrm{ppm})$. This is thought to reflect higher oxidizing conditions in PEL69h, arising from the use of fully oxidized S along with elevated water contents.

Unlike in basaltic melts, melt sulphur contents are not correlated with melt $\mathrm{FeO}$ contents (Table 3), as already shown previously (e.g. Clemente et al., 2004; Prouteau \& Scaillet, 2013). Finally, we note that the peraluminous glasses produced here have sulphur contents lower by a factor of 1.5-2 relative to trondhjemitic glasses produced at the same conditions in the basaltic system (melts saturated in pyrrhotite and anhydrite) (Fig. 8a; Prouteau \& Scaillet, 2013), in line with the observation that high alkali content enhances sulphur solubility in felsic melts (Scaillet \& Macdonald, 2006).

\section{Trace element chemistry}

$\mathrm{H}_{2} \mathrm{O} \pm \mathrm{H}_{2} \mathrm{SO}_{4}$-doped charges have not been analysed for trace elements, as glass pools were too small for successful analysis. Glasses in other charges are relatively homogeneous in trace element composition, as evidenced by multiple analyses (5-6) showing standard deviations of typically $\leq 10 \%$. Mineral phases proved to be more difficult to analyse, due to their small

size, crystal habit or inclusions, and core-to rim trace element zoning could not be determined. Standard deviations are typically around $10 \%$, but can reach $50 \%$ for some elements ( $\mathrm{Yb}$ in garnet, $\mathrm{Pb}$ in sulphide). The micron-size monazite, rutile, zircon were too small to be reliably analysed by LA-ICP-MS.

In experiments where all host phases were analysed, mass balance for trace elements was good generally, and no evidence for "open system" behaviour was observed, except for 
$\mathrm{Pb}$ in high temperature $\left(>850^{\circ} \mathrm{C}\right)$ experiments, for which lead contamination, probably through the lead sheet surrounding the talc-pyrex assembly, is suspected.

\section{Trace element composition of minerals}

Garnet is the main host for Y and HREE (Heavy Rare Earth Elements) and is slightly enriched in Li, actinides (Th, U), Zr, Hf and MREE (Supplementary Data 2). LREE, MREE, $\mathrm{Zr}$ and $\mathrm{Hf}$ contents decrease in garnet with addition of S. Orthopyroxene is poor in trace elements but contains up to $61 \mathrm{ppm}$ lithium (Supplementary Data 2). Micas are the main host for $\mathrm{Rb}$ and $\mathrm{Ba}$. Phengite is also enriched in $\mathrm{Li}(30-60 \mathrm{ppm}), \mathrm{B}(40-60 \mathrm{ppm}), \mathrm{Nb}$ and $\mathrm{Pb}$ (Supplementary Data 2). B, La, Ce, $\mathrm{Pb}$ and Th contents increase in phengite with addition of $\mathrm{S}$ at fixed T. Biotite, produced in S-doped experiments (1 and $2.1 \mathrm{wt} . \% \mathrm{~S}_{\text {in }}$ ), is the second major host for $\mathrm{Rb}$ and $\mathrm{Ba}$, with $\mathrm{Ba}$ contents lower than in phengite (1500-2200 ppm in phengite vs. 700-1300 ppm in biotite; Supplementary Data 2). Biotite is enriched in Li (50120 ppm), B (up to 120 ppm) and Pb (Supplementary Data 2). Sulphides have low $\mathrm{Pb}$ contents $(<25$ ppm; Supplementary Data 2$)$. Semi-quantitative analyses of monazite (Supplementary Data 3) suggest that it is Ce-rich in S-undoped experiments and that the addition of S decreases LREE ( $\mathrm{La}, \mathrm{Ce}, \mathrm{Nd}$ ) and $\mathrm{P}$ contents and increases $\mathrm{Ca}$ and $\mathrm{S}$ contents (so-called "anhydrite-celestine" substitution, see Chakhmouradian \& Mitchell, 1999; Krenn et al., 2011).

Trace element composition of quenched glasses

The trace element compositions of quenched glasses are given in Table 4. The primitive mantle (McDonough \& Sun, 1995) normalized multi-element plots (Fig. 9) illustrate that the 
experimental glasses display numerous features typical of arc magmas: fractionated REE pattern, negative anomalies in $\operatorname{HFSE}(\mathrm{Nb}, \mathrm{Ta}, \mathrm{Ti}$ and $\mathrm{Zr}$ to a lesser extent), selective enrichment in alkalis, earth alkalis, light elements and strong positive $\mathrm{Pb}$ anomalies. This geochemical pattern mimics the overall characteristics of the starting sediment, suggesting that high pressure melting can preserve this source signature.

In detail, with increasing temperature (and degree of partial melting), at fixed total $\mathrm{S}$ content, the concentration of light elements ( $\mathrm{Li}, \mathrm{Be}, \mathrm{B})$ decreases, together with $\mathrm{Sr}$ contents, due to progressive dilution as the melt proportion increases (Figs 9b, 9c). Rb and $\mathrm{Ba}$ mimic the behaviour of $\mathrm{K}_{2} \mathrm{O}$ : their concentrations first increase with temperature and then decrease upon micas breakdown (Fig. 9d). HFSE (Nb, Ta, Zr, Hf) contents increase from $750^{\circ} \mathrm{C}$ to $1000^{\circ} \mathrm{C}$, owing to the increase in solubility of rutile and zircon with temperature (Fig. 9e). $\mathrm{Zr} / \mathrm{Hf}$ ratios are sub-chondritic $\left(<37.1 ; \mathrm{McD}\right.$ onough $\&$ Sun, 1995) except in $1000^{\circ} \mathrm{C}$ garnetfree charges $(\mathrm{Zr} / \mathrm{Hf}=41.7)$. Similarly, $\mathrm{Nb} / \mathrm{Ta}$ ratios are systematically sub-chondritic $(<17.6$, McDonough \& Sun, 1995) and increase with increasing temperature (e.g. $\mathrm{Nb} / \mathrm{Ta}$ increases in the S-undoped experiments from 3.1 to 16.4 with temperature increasing from $750^{\circ} \mathrm{C}$ to $900^{\circ} \mathrm{C}$, Table 4). $\mathrm{Pb}$ concentrations decrease from 750 to $850^{\circ} \mathrm{C}$ (e.g. in the S-undoped experiments, $\mathrm{Pb}$ contents decreases from $63.5 \mathrm{ppm}$ to $53.6 \mathrm{ppm}$ with temperature increasing from $750^{\circ} \mathrm{C}$ to $850^{\circ} \mathrm{C}$ ), with no clear trend at higher temperature (Table 4). Finally, LREE and Th contents increase up to $800-850^{\circ} \mathrm{C}$ and then decrease once monazite is exhausted from the residue (Fig. 9f).

At fixed $\mathrm{T}$, adding $\mathrm{S}$ leads to a decrease of $\mathrm{Rb}, \mathrm{Ba}$ and $\mathrm{Sr}$ contents in melts while HFSE (Nb, Ta, Zr) contents increase. MREE (Sm, Eu), Y and HREE (Dy, Yb) contents strongly increase in the melt (Fig. 9g) while garnet is progressively destabilised with the addition of sulphur. 


\section{Mineral-melt partition coefficients}

All mineral-melt partition coefficients are calculated using raw trace element compositions of hydrous quenched glasses, without taking into account possible fluid exsolution on quenching. Mineral-melt partition coefficients are plotted for a range of trace elements in Fig. 10 (Li, Be, B, LILE, HFSE, actinides, Pb, Y, REE). The partition coefficients ( $\left.\mathrm{D}^{\text {solid/melt }}\right)$ in garnet, orthopyroxene, micas and sulphide are listed in Tables 5, 6, 7 and 8, respectively.

Garnet. Partition coefficients (Drttmelt, Fig. 10a) generally agree well with previous determinations at similar conditions (Klimm et al., 2008; Skora \& Blundy, 2010). HREE and $\mathrm{Y}$ are systematically compatible in garnet, whatever the temperature and sulphur content (Fig. 10a). In general, temperature influences the partition coefficients, at fixed $\mathrm{S}$, with $\mathrm{D}^{\mathrm{Gr} / \mathrm{melt}}$ decreasing with increasing temperature (and decreasing $X_{\text {grossular }}$ ), consistent with previous studies (van Westrenen et al., 2001; Skora \& Blundy, 2010). For low temperature conditions ( $\mathrm{T} \leq 850^{\circ} \mathrm{C}$, with $X_{\text {grossular }}$ between 1.8 and $10 \%$ ), MREE (Sm, Eu), Ti and $\mathrm{Zr}$ are compatible in garnet except for high $\mathrm{X}_{\mathrm{Mg}}$ garnet synthesized in PEL79 $\left(850^{\circ} \mathrm{C} ; 2.1 \mathrm{wt} . \% \mathrm{~S}_{\mathrm{in}}\right)$. For experiments performed at $900^{\circ} \mathrm{C}, \mathrm{Eu}, \mathrm{Ti}$ and $\mathrm{Zr}$ are compatible in garnet. When $\mathrm{S}$ content increases ( $\mathrm{T}$ fixed), $\mathrm{D}^{\mathrm{Grt} / \text { melt }}$ for $\mathrm{Zr}$, Hf, MREE, $\mathrm{Y}$ and HREE decrease. Incompatible elements with $\mathrm{D}^{\mathrm{Gr} t / m e l t}<1$ are $\mathrm{Li}, \mathrm{Th}, \mathrm{U}, \mathrm{Nb}, \mathrm{Ce}$ and $\mathrm{Pb}$. The most incompatible elements, with $\mathrm{D}^{\text {Grt/melt }}$ $<0.03$, at all temperatures and sulphur contents, are La and LILE ( $\mathrm{Rb}, \mathrm{Ba}, \mathrm{Sr})$. Garnet strongly fractionates LREE and LILE from HREE and further causes small fractionation by preferring $\mathrm{Zr}$ over $\mathrm{Hf}\left(\mathrm{D}_{\mathrm{Zr}} / \mathrm{D}_{\mathrm{Hf}} \sim 1.3-1.9\right)$ and $\mathrm{U}$ over $\mathrm{Th}\left(\mathrm{D}_{\mathrm{U}} / \mathrm{D}_{\mathrm{Th}}=1.1-6.7\right)$. $\mathrm{D}_{\mathrm{Zr}} / \mathrm{D}_{\mathrm{Hf}}$ are inversely correlated to experimental temperature, and therefore decrease with $X_{\text {grossular }}$. Conversely, $\mathrm{D}_{\mathrm{U}} / \mathrm{D}_{\text {Th }}$ increases with increasing temperature and decreasing $X_{\text {grossular }}$, consistent with Klimm et al. (2008) and Skora \& Blundy (2010) results. Therefore, garnet crystallizing in Ca-poor sediments can efficiently fractionate $\mathrm{U}$ and $\mathrm{Th}$, inducing a selective enrichment of 
Th in the corresponding melt, in contrast to what is observed for Ca-rich systems (e.g. in MORB, Klimm et al., 2008).

Orthopyroxene. Partition coefficients $\left(\mathrm{D}^{\mathrm{Opx} / \mathrm{melt}}\right)$ for two experiments are presented in Fig. 10b. $\mathrm{D}^{\text {Opx } / \text { melt }}$ are systematically $<1$. The less incompatible elements, with $\mathrm{D}^{\text {Opx } / \text { melt }}>0.1$, are Li, Be, Nb, Ta, Ti, Dy, Y and Yb.

Phengite. Partition coefficients $\left(\mathrm{D}^{\mathrm{Ph} / \mathrm{melt}}\right)$ from three experiments (PEL71, PEL72 and PEL50) are shown in Fig. 10c. Elements with $\mathrm{D}^{\mathrm{Ph} / \text { melt }}$ values around 1-10 include $\mathrm{Rb}, \mathrm{Ba}, \mathrm{Nb}$ and $\mathrm{Ti} . \mathrm{D}^{\mathrm{Ph} / \mathrm{melt}}$ for $\mathrm{Li}$ and $\mathrm{B}$ are $<1$. There are no published partition coefficients for light elements in phengite. However, $D_{L i}^{P h / m e l t}(0.3-0.6)$ are slightly greater than $D_{L i}^{m u s c o v i t e / m e l t}$ $(0.12-0.24)$ determined at low pressure and temperature in peraluminous rhyolite $(3 \mathrm{kbar}$, $620^{\circ} \mathrm{C}$; Pichavant et al., 2016). At constant temperature, $\mathrm{D}^{\mathrm{Ph} / \text { melt }}$ for LILE, Th, LREE and $\mathrm{Pb}$ increases with sulphur content. Phengite fractionates $\mathrm{Ba}$ from $\mathrm{Rb}\left(\mathrm{D}_{\mathrm{Ba}}>\mathrm{D}_{\mathrm{Rb}}\right)$ and $\mathrm{U}$ from $\mathrm{Th}$ $\left(\mathrm{D}_{\mathrm{U}}>\mathrm{D}_{\mathrm{Th}}\right)$ (Fig. 10c).

Biotite. Partition coefficients $\left(\mathrm{D}^{\mathrm{Bt} / \mathrm{melt}}\right)$ for two experiments doped with $2.1 \mathrm{wt} . \% \mathrm{~S}$ are shown in Fig. 10d. As observed for phengite, partition coefficients for LILE ( $\mathrm{Rb}, \mathrm{Ba})$ and Ti are $>1$, with $D_{R b}>D_{B a}$, but $D_{N b}<1$. As in phengite, light elements (Li, B) are incompatible ( $D_{L i}^{B t} /$ melt $=0.49$ to 0.65 and $\left.D_{B}^{B t / m e l t} \sim 0.05\right)$. These low $\mathrm{D}_{\mathrm{Li}}$ in biotite are in agreement with previous determinations at low pressure ( $D_{L i}^{B t / m e l t}$ : 0.41-1.00; Pichavant et al., 2016).

Sulphide. Partition coefficients for $\mathrm{Pb}$ are presented in Table $8 . \mathrm{D}_{\mathrm{Pb}}$ are systematically below unity ( 0.13 to 0.54$)$ and poorly correlated to the temperature in the range investigated, consistent with partition coefficients for similar melt compositions at lower pressures $(0.5-1.5$ GPa; Li \& Audétat, 2015).

\section{DISCUSSION}


The systematic geochemical trends displayed by both glass and minerals and their coherent variations with experimental variables argues that conditions close to equilibrium were attained, with the exception of experiments performed at $750^{\circ} \mathrm{C}$, in which staurolite occurrence suggests that steady state is not fully attained (see above). The wet solidus at 3 GPa has not been bracketed in our study, but our results show that, whatever the bulk sulphur content, it lies below $750^{\circ} \mathrm{C}$, in agreement with previous experimental studies on similar bulk compositions (Hermann \& Spandler, 2008). Below we first examine melting reactions for Sand Ca-poor oceanic metasediments by reference to previous similar works and then consider the effect of sulphur.

\section{Phase relations and melting reactions of $S$ - and Ca-poor pelites}

Previous experiments on subducted crust have demonstrated that the transition from biotitebearing to phengite-bearing parageneses occurs at $\mathrm{P} \sim 2.5$ GPa not only in metapelites, but also in greywacke and K-bearing MORB (Schmidt et al., 2004b; Auzanneau et al., 2006; Hermann \& Spandler, 2008). Our results for S-undoped experiments confirm this finding. However, the upper temperature stability for phengite in previous studies occurs above $850^{\circ} \mathrm{C}$ (e.g. Johnson \& Plank, 1999; Skora \& Blundy, 2010), whilst phengite is no more stable above $800^{\circ} \mathrm{C}$ in our runs (Figs 3, 4). The lower thermal stability of phengite might be due to elevated $\mathrm{H}_{2} \mathrm{O}$ contents employed here, since it has been shown that a low $\mathrm{H}_{2} \mathrm{O}$ content enhances the phengite stability field in high pressure pelites (up to $880-950^{\circ} \mathrm{C}$ at $3 \mathrm{GPa}$, for $\mathrm{H}_{2} \mathrm{O} \sim 1.5$ wt. \%, Mann \& Schmidt, 2015). A high $\mathrm{K}_{2} \mathrm{O} / \mathrm{H}_{2} \mathrm{O}$ ratio also enhances phengite stability (e.g. Hermann \& Spandler, 2008; Skora \& Blundy, 2010). For instance, with a bulk $\mathrm{K}_{2} \mathrm{O} / \mathrm{H}_{2} \mathrm{O}=$ 0.46 , phengite persists to high temperature $\left(>900^{\circ} \mathrm{C}\right)$ in the pelitic composition of Hermann \& Spandler (2008). The low bulk $\mathrm{K}_{2} \mathrm{O} / \mathrm{H}_{2} \mathrm{O}$ ratio (0.26) of our starting product could thus also 
explain the low temperature of phengite breakdown. We note that our starting composition contains 900 ppm $\mathrm{S}$ and is rich in halogens and $\mathrm{CO}_{2}$ (Table 1), as many subducted sediments (e.g. Li \& Schoonmaker, 2014), which could also affect phengite as we show below for sulphur (see Prouteau \& Scaillet, 2013).

Phase proportions show systematic changes with temperature, which provide guidance on melting reactions. With increasing temperature, for $\mathrm{T} \leq 850^{\circ} \mathrm{C}$, we observe a significant decrease in the abundance of phengite and, to a lesser extent, $\mathrm{SiO}_{2}$ phase, whereas there is a strong increase in the amount of melt and a smaller increase in garnet mode. Garnet mode peaks at $850^{\circ} \mathrm{C}$, where phengite is exhausted and $\mathrm{SiO}_{2}$ (quartz) occurs only in low amounts. Kyanite abundance remains relatively constant in this melting interval (Table 2). These observations suggest the following incongruent melting reaction (Schmidt, 1996; Hermann \& Green, 2001; Poli \& Schmidt, 2002; Hermann \& Spandler, 2008; Skora \& Blundy, 2010; Mann \& Schmidt, 2015):

Qtz/Coe $\pm \mathrm{Cpx}+\mathrm{Phe}+\mathrm{H}_{2} \mathrm{O} \rightarrow \mathrm{Grt}+$ Melt $(2)$

Here, because of the Ca-poor composition $\left(\mathrm{X}_{\mathrm{Ca}}=0.05\right)$, all the clinopyroxene has been melted out.

At $>850^{\circ} \mathrm{C}$, beyond phengite-out, there is a clear change in the melting reaction, with melt fraction increasing at the expense of garnet and quartz, while kyanite mode remains constant (Table 2). This suggests that - above $850^{\circ} \mathrm{C}$ - garnet lies on the reactant, not on the product, side. This coincides with a significant change in melt composition (e.g. strong increase in $\mathrm{FeO}$ between 850 and $900^{\circ} \mathrm{C}$, from 1.7 wt. \% to 2.9 wt. \%), consistent with Fe-rich garnet being consumed via a congruent reaction such as (e.g. Auzanneau et al., 2006; Skora \& Blundy, 2010):

Qtz/Coe + Grt + Fluid $\rightarrow$ Melt 
It is worth noting that there is a remarkable difference in melt productivity between low $\mathrm{T}$ reaction (2) and high T reaction (3). Melt productivity has a steep trend until around $850^{\circ} \mathrm{C}$, above which the trend flattens out (Fig. 11). Approximately 60 wt. \% of the melt is generated at $850^{\circ} \mathrm{C}$, whereas a temperature increase to $1000^{\circ} \mathrm{C}$ produces only $10 \mathrm{wt} . \%$ more melt. A comparable evolution of melt productivity has been described for the hydrous melting of a radiolarian clay, with 15 wt. $\% \mathrm{H}_{2} \mathrm{O}$ (Skora \& Blundy, 2010). In contrast, the melt productivity of pelite is considerably lower, at fixed $\mathrm{T}$, for less hydrated system $(\sim 30 \%$ melt at $850^{\circ} \mathrm{C}$ with 4.4 wt. $\%$ bulk $\mathrm{H}_{2} \mathrm{O}$, Mann \& Schmidt, 2015). Altogether, these observations confirm that the proportion of phengite ultimately controls melt productivity at high pressure and that this is considerably enhanced by the addition of water, even at relatively low temperatures (e.g. Schmidt et al., 2004b).

\section{Effect of sulphur on phase relations and melting reactions}

The addition of sulphur to the experimental charges results in precipitation of sulphides (as long as $f \mathrm{O}_{2}$ is not too oxidizing), in increasing proportions with more $\mathrm{S}$ input (Table 2), following the common reaction (1):

$\mathrm{FeO}_{\text {bulk }}+\frac{1}{2} \mathrm{~S}_{2} \rightarrow \mathrm{FeS}_{\text {pyrrhotite/melt }}+\frac{1}{2} \mathrm{O}_{2}$

By virtue of the reaction (1), the increase in elemental S content is therefore coupled with an increase in $\mathrm{fO}_{2}$, the two effects cannot be disentangled in our experiments.

The stability of pyrrhotite in our experiments in the $\mathrm{fO}_{2}$ range investigated, together with the absence of anhydrite, are consistent with previous experiments performed on Ca-poor sediments (Prouteau \&Scaillet, 2013) and with the empirical model of sulphide-sulphate stability in subducting sediments of Canil \& Fellows (2017). Because a significant part of iron is locked into sulphide, the $\mathrm{X}_{\mathrm{Mg}}$ of other Fe-Mg coexisting phases increases. In particular, 
liquid, garnet, and micas have systematically higher $\mathrm{X}_{\mathrm{Mg}}$ compared with sulphur-undoped experiments (e.g. Fig. 5b, 6c, 7c), an observation previously made in low (e.g. Scaillet \& Evans, 1999; Costa et al., 2004; Parat et al., 2008) or high (Prouteau \& Scaillet, 2013) pressure experiments on silicic magmas, but also on single Fe-Mg silicate phases alone (e.g. Popp et al., 1977). For sulphide-saturated experiments, the more sulphur is added, the more iron is held by sulphide and, as a result, the more the coexisting liquid and ferro-magnesian silicate phases are Mg-rich.

Adding $\mathrm{S}$ at $800^{\circ} \mathrm{C}$ favours the crystallization of biotite in lieu of phengite, thereby confirming that S affects the stability field of phengite (Prouteau \& Scaillet, 2013), and expands the biotite stability field toward higher pressure. At $800^{\circ} \mathrm{C}$, the addition of sulphur decreases garnet, phengite and melt proportions and increases biotite, kyanite and $\mathrm{SiO}_{2}$ abundances (Figs 3, 4) suggesting therefore that S promotes a reaction of the form (e.g. Massonne \& Szpurka, 1997; Hermann, 2002; Thomsen \& Schmidt, 2008) :

Garnet + Phengite $+\mathrm{S} \rightarrow \mathrm{FeS}+$ Biotite + Kyanite $+\mathrm{SiO}_{2}$

This goes along with a decrease in melt proportion relative to the S-undoped system and a higher modal amount of biotite relative to that of phengite (Fig. 3). Therefore reaction (4) with sulphur may be tentatively written as:

$2 \mathrm{Fe}_{3} \mathrm{Al}_{2} \mathrm{SiO}_{12}+\mathrm{KAl}_{2} \mathrm{Si}_{3} \mathrm{AlO}_{10}(\mathrm{OH})_{2}+1 / 2 \mathrm{~K}_{2} \mathrm{O}_{\text {melt }}+\mathrm{FeO}_{\text {melt }}+5 \mathrm{SiO}_{2 \text { melt }}+1 / 2 \mathrm{Al}_{2} \mathrm{O}_{3 \text { melt }}+\mathrm{H}_{2}+\mathrm{S}$

$\rightarrow 2 \mathrm{KFe}_{3}(\mathrm{OH})_{2} \mathrm{Si}_{3} \mathrm{AlO}_{10}+3 \mathrm{Al}_{2} \mathrm{SiO}_{5}+\mathrm{FeS}+\mathrm{SiO}_{2 \text { quartz }}+4 \mathrm{O}_{2}$

with melt components on the reactant side. Only a few experiments of sediments partial melting at $\mathrm{P}>3 \mathrm{GPa}$ have reported biotite in their run products (Hermann \& Green, 2001 and Hermann, 2002 (synthetic sediment - KCMASH); Nichols et al., 1994 (natural clay); Martindale et al., 2013 (natural volcaniclastic sediments)). Comparison of phase relations between Fe-free and Fe-bearing (natural) systems shows that Fe widens the stability field of garnet + phengite (Hermann, 2002). Bulk FeO content has been shown to control the overall 
biotite stability and biotite to phengite reactions in sediments (Thomsen \& Schmidt, 2008) and our results suggest that high $\mathrm{S}$ has a similar effect by scavenging Fe via sulphide crystallization.

In the $800-850^{\circ} \mathrm{C}$ temperature range, melting involves consumption of biotite, quartz and, to a lesser extent, kyanite, with the production of glass and garnet $\left(1 \mathrm{wt} \% \mathrm{~S}_{\text {in }}\right)$ or garnet + orthopyroxene $\left(2.1\right.$ wt. $\left.\% \mathrm{~S}_{\text {in }}\right)$ (Figs 3,4$)$. These observations suggest that biotite reacts out via an incongruent melting reaction of the form:

$\mathrm{Bt} \pm \mathrm{Cpx}+\mathrm{Qz} / \mathrm{Coe}+\mathrm{Ky}+\mathrm{H}_{2} \mathrm{O} \rightarrow \mathrm{Grt} \pm \mathrm{Opx}+\mathrm{Melt}$

A somewhat similar equation, with kyanite on the reactant side, was proposed by Hermann \& Green (2001) as being the high-P biotite-melting reaction in KCMASH model system. At fixed $\mathrm{T}$, melt productivity via reaction (6) is lower than for the phengite-melting reaction (reaction 2), owing to the higher thermal stability of biotite compared to that of phengite (Fig. 4). As more sulphur is added to the system, more biotite is present in the residue and the melt productivity is lower.

Above $800^{\circ} \mathrm{C}$, i.e. beyond the mica stability field, garnet proportion strongly decreases with increasing sulphur content at fixed T. Orthopyroxene crystallizes together with $\left(850^{\circ} \mathrm{C}\right)$, or instead of $\left(900^{\circ} \mathrm{C}\right)$, garnet in the $2.1 \mathrm{wt} . \% \mathrm{~S}_{\text {in }}$ runs. The growth of orthopyroxene is correlated to a moderate increase in kyanite. The following reaction may qualitatively account for garnet consumption in the presence of sulphur:

$2 \mathrm{Fe}_{3} \mathrm{Al}_{2} \mathrm{SiO}_{12}+5 \mathrm{~S} \rightarrow 5 \mathrm{FeS}+\mathrm{FeAl}_{2} \mathrm{SiO}_{6}+\mathrm{Al}_{2} \mathrm{SiO}_{5}+1 / 2 \mathrm{O}_{2}$

where $\mathrm{Fe}_{3} \mathrm{Al}_{2} \mathrm{SiO}_{12}$ is the almandine component in garnet and $\mathrm{FeAl}_{2} \mathrm{SiO}_{6}$ the Fe-tschermak component in orthopyroxene.

Orthopyroxene and orthopyroxene-kyanite stability fields have been bracketed in high pressure experimental melting of Fe-free model composition (KCMASH, Hermann \& Green, 2001; Hermann, 2002). Orthopyroxene is not a common high-pressure phase in crustal rocks 
(e.g. Hermann, 2002), but orthopyroxene coexisting with kyanite has been described to form in cracks in pyrope megablasts in white schist of the Dora Maira Massif (Simon \& Chopin, 2001). The enstatite in equilibrium with kyanite contains typically about 3 wt. \% but up to 8.4 wt. $\% \mathrm{Al}_{2} \mathrm{O}_{3}$, which is in the range of the experimentally grown orthopyroxenes at $850-900^{\circ} \mathrm{C}$. This suggests that orthopyroxene and kyanite can be an ultrahigh-pressure assemblage in very Mg-rich rock types (see also discussion in Hermann, 2002).

Above $800^{\circ} \mathrm{C}$, the melt fraction increases at the expense of garnet $\left(1 \mathrm{wt} . \% \mathrm{~S}_{\text {in }}\right)$, orthopyroxene $\left(2.1 \mathrm{wt} . \% \mathrm{~S}_{\text {in }}\right)$ and quartz. This suggests that melting is governed by a congruent reaction, similar to reaction (3) in sulphur-poor pelite, such as:

$\mathrm{Qz} / \mathrm{Coe} \pm \mathrm{Grt} \pm \mathrm{Opx}+$ Fluid $\rightarrow$ Melt

Melt productivity displays a trend in sulphur-rich sediments very similar to that observed in S-undoped charges, namely a steep trend upon reaction (6), in biotite stability field, and a flat trend upon reaction (8) (Fig. 11). The dissolution of anhydrous Fe-Mg phases is enhanced by high $\mathrm{S}$ bulk contents, inducing higher melt productivities at fixed T (Fig. 11). This is indicative of a small but detectable flushing role of sulphur at high pressures and for T $>850^{\circ} \mathrm{C}$, as already observed for basaltic lithologies (Prouteau \& Scaillet, 2013). In contrast, as discussed above, the opposite is observed in the low temperature range.

It is worth noting that the influence of sulphur on phase relationships observed in our experiments (namely, decreasing garnet mode with sulphide content, high $\mathrm{X}_{\mathrm{Mg}}$ in silicate ferro-magnesian phases) has also been documented during the sulphidation of low grade pelitic rocks. For instance, Guidotti (1970) notices that garnet decreases modally with increasing sulphide content in silllimanite grade pelitic rocks in the Oquossoc area (Maine), biotite being greatly enriched in Mg in sulphide-rich samples. Similarly, Tracy \& Robinson (1988) show that very magnesian assemblages (e.g. more magnesian biotite and cordierite) were produced through sulphidation of granulite-grade pelitic rocks from Massachusetts; in 
the presence of an $\mathrm{H}_{2} \mathrm{~S}$-rich fluid, Fe is progressively and effectively removed from the reactive bulk composition of the rock and sequestered in sulphides. Nesbitt (1986a, b) developed equations and calibrations to document the responses of silicate-oxide-sulphide assemblages to variations in $\mathrm{fS}_{2}$ (among other parameters) in metamorphic rocks. His results indicate that increasing $\mathrm{fS}_{2}\left(\right.$ or $\left.\mathrm{fO}_{2}\right)$ induces, for example, the disappearance of garnet and the increase of $\mathrm{X}_{\mathrm{Mg}}$ in ferro-magnesian phases, as reported here. Lastly, such sulphide-silicate reactions have been also documented for prograde sulphide metamorphism in blueschist and eclogite (metasediment and metabasalt) from New Caledonia (Brown et al., 2014).

It therefore appears that introduction of $\mathrm{S}$ in subsolidus or partially melting rocks drives Fe$\mathrm{Mg}$ silicates towards Mg-rich compositions.

\section{Implications for subduction zone chemical fluxes}

\section{Sulphur contents of peraluminous hydrous felsic melts at high pressure}

Sulphide is the stable phase in all hydrous $\left(8.5 \mathrm{wt}\right.$. \% total $\left.\mathrm{H}_{2} \mathrm{O}\right)$ experiments undoped or doped with elemental sulphur (Table 2). In contrast, partially melted Ca-rich oceanic basalt is saturated in sulphide and sulphate at equivalent $\mathrm{P}-\mathrm{T}-\mathrm{H}_{2} \mathrm{O}-f \mathrm{O}_{2}$ conditions and $\mathrm{S}$ contents (Prouteau \& Scaillet, 2013). These experiments used the same assembly and vessel as the present study, which rules out experimental conditions as being not appropriate (i.e. too reducing) for anhydrite crystallization per se. Instead, the lack of anhydrite reflects primarily the Ca-poor character of our starting material. In particular, our results confirm the prediction of Carroll \& Rutherford (1987) that magmas with high normative diopside (i.e. high Ca content) crystallize anhydrite at lower $f \mathrm{O}_{2}$ than those with low Ca. Canil \& Fellows (2017), also documented a shift of the sulphide/sulphate (SSO) buffer to higher $f \mathrm{O}_{2}(\sim 1 \log$ unit at 
2.5 GPa) for low bulk $\mathrm{X}_{\mathrm{Ca}}$ pelitic composition. Sulphide has not been identified in charge PEL68h, which has a higher bulk $\mathrm{H}_{2} \mathrm{O}$ content $\left(15\right.$ wt. $\left.\% \mathrm{H}_{2} \mathrm{O}\right)$. The lack of sulphide in this charge is presumably due to higher $f \mathrm{O}_{2}$ resulting from higher $f \mathrm{H}_{2} \mathrm{O}$. Charge PEL69h is doped with a solution of $\mathrm{H}_{2} \mathrm{SO}_{4}\left(1\right.$ wt. $\% \mathrm{~S}_{\text {in }}$ as $\mathrm{S}^{6+} ; 15$ wt. $\left.\% \mathrm{H}_{2} \mathrm{O}\right)$ and has trace amounts of sulphide, but anhydrite occurrence is only inferred.

The experiments carried out with a $\mathrm{MgO}$ filler (i.e. more oxidizing) show significantly higher melt sulphur contents than those performed with a BN filler (i.e. less oxidizing). For instance, with a BN filler, the melt sulphur content is about $150 \mathrm{ppm}$ at $800^{\circ} \mathrm{C}$ and $\mathrm{S}_{\text {in }}=2.1 \mathrm{wt} . \%$ and reaches $\sim 830 \mathrm{ppm}$ with a $\mathrm{MgO}$ filler at $750^{\circ} \mathrm{C}$ and $\mathrm{S}_{\mathrm{in}}=2.1 \mathrm{wt} . \%$ (Fig. 8a, Table 3). This highlights the key role of $\mathrm{fO}_{2}$ on the sulphur content at sulphide saturation (SCSS) (e.g., Carroll \& Rutherford, 1985, 1987; Jugo, 2009; Li \& Audétat, 2013, 2015).

For a given filler, melt sulphur contents at sulphide saturation (SCSS) increase with temperature or total sulphur content (Table 3, Fig. 8a). As Stolper et al. (1987) have emphasized, the bulk effect of temperature on volatile solubility in silicate melts is controlled by the energetic balance between the reactions controlling molecular (e.g. $\mathrm{H}_{2} \mathrm{~S}$ ) and anion groups' solubilities (e.g. $\mathrm{HS}^{-}, \mathrm{SO}_{4}^{2-}$ ). In general, the solubility of molecular species decreases with T (Stolper et al., 1987; Fogel \& Rutherford, 1990), whereas the abundance of species formed by reaction with the melt is enhanced by temperature (e.g. Zhang, 1999). The fact that the SCSS has a positive temperature dependence, as observed in previous studies, might be therefore interpreted as the dominant presence of anion group species over molecular species in rhyolite melts (see Clemente et al., 2004). The increase in SCSS with increasing amount of sulphur added to the system suggests that the $\mathrm{fO}_{2}$ within the capsules increases with increasing $\mathrm{S}_{\mathrm{in}}$, by virtue of the reaction (1) (see above). However, we can not exclude also the additional role of pyrrhotite composition (i.e. varying Fe/S atomic ratios with bulk sulphur content) or melt composition (e.g. alkali contents). For instance, Clemente et al. (2004) have 
shown that, in rhyolite melts, the $\mathrm{fS}_{2}$ (given by pyrrhotite compositions or calculated from MRK-EOS approach) is a function of the initial amount of sulphur in the charge and of the imposed experimental conditions. They have shown that $\mathrm{fS}_{2}$ exerts a dominant control on the sulphur solubility in hydrous silicate melts, which increases with $\mathrm{fS}_{2}$ (Clemente et al., 2004). By adding sulphur to the starting material, we changed the $\mathrm{fS}_{2}$ of the system (see also Prouteau \& Scaillet, 2013). However, as we did not determine the $\mathrm{fS}_{2}$ in our experiments, its impact on SCSS cannot be properly disentangled from the control of $\mathrm{fO}_{2}$.

With a total 2.2 wt. \% sulphur content in the source, a hyperaluminous, hydrous $\left(\mathrm{H}_{2} \mathrm{O}\right.$ $>20$ wt. \%) felsic $\left(\mathrm{SiO}_{2} \sim 75 \%\right)$ sulphide-saturated melts produced at $750{ }^{\circ} \mathrm{C}$ can achieve $>$ 800 ppm S content (Table 3, Fig. 8a). Melts produced at $900^{\circ} \mathrm{C}$ in $\mathrm{H}_{2} \mathrm{SO}_{4}$ doped experiment (1 wt. $\% \mathrm{~S}_{\text {in }}, 15$ wt. $\% \mathrm{H}_{2} \mathrm{O}$ ) achieves the highest $\mathrm{S}$ content of our study (3500 ppm). These observations are consistent with previous studies that show that oxidized conditions enhances the solubility of S (e.g. Carroll \& Rutherford, 1987; Luhr, 1990; Scaillet et al., 1998; Jugo et al., 2005; Prouteau \& Scaillet, 2013; Jégo \& Dasgupta, 2014; Canil \& Fellows, 2017). In the $750-800^{\circ} \mathrm{C}$ temperature range, corresponding to the slab top temperature of most subduction zones (Syracuse et al., 2010), melts at sulphide saturation of the S-undoped experiments represent a small fraction $(<10 \%)$ of the sulphur inventory in the source (Supplementary Data 4). The proportion of pyrrhotite increases with the bulk sulphur content at fixed $\mathrm{T}$ and $f \mathrm{O}_{2}$ (Table 2) and, consequently, the fraction of $\mathrm{S}$ removed from the source by the silicate melt decreases with sulphur content (Supplementary Data 4). At higher temperatures $\left(850^{\circ} \mathrm{C}\right.$ and $900^{\circ} \mathrm{C}$ ), melt can transfer a larger proportion (up to $\sim 50$ wt. \%) of the total sulphur initially present, provided the residue contains only trace amount of sulphide, as is the case for the most oxidizing conditions for S-undoped experiments (Supplementary Data 4).

Considering that the mantle wedge is metasomatized by a few $\%$ of such sedimentsourced hydrous melts (less than $\sim 5 \mathrm{wt} . \%$, based on isotopic studies for most sediment-rich 
arc magmas, e.g. Carpentier et al., 2008), high $f \mathrm{O}_{2}$ and/or high $\mathrm{S}$ content in the source $(\sim 4 \mathrm{wt}$. $\%$, Prouteau \& Scaillet, 2013) are implied if the S enrichment of arc magma mantle source occurs by this process alone.

\section{LIL and light elements transfer}

LIL elements. The first melt $\left(750^{\circ} \mathrm{C}\right)$ generated at sub-arc depths from a S-undoped hydrous pelite is strongly trondhjemitic (Figs 7f, $7 \mathrm{~g}$ ), a result of the buffering role of phengite on residual melt composition. Our results indicate that phengite stability is sensitive to sulphur content, and that biotite replaces phengite in sulphur-rich systems, thus buffering melt $\mathrm{K}_{2} \mathrm{O}$ content at higher temperatures. In this way, the $\mathrm{K}_{2} \mathrm{O} / \mathrm{Na}_{2} \mathrm{O}$ ratios of low temperature (i.e. in the micas stability domain) anatectic melts at high pressure will depend not only on the bulk $\mathrm{K}_{2} \mathrm{O} / \mathrm{H}_{2} \mathrm{O}$ and temperature, but also on the sulphur content. This could explain the large range of $\mathrm{K}_{2} \mathrm{O} / \mathrm{Na}_{2} \mathrm{O}$ and $\mathrm{S} / \mathrm{K}_{2} \mathrm{O}$ analysed in melt inclusions in mantle xenoliths, inferred to represent infiltrating slab melts in mantle wedge (e.g. Kepezhinskas et al., 1995, 1996; Schiano et al., 1995; Métrich et al., 1999; Vannucci et al., 2007; Turner et al., 2012), or in IAB melt inclusions (Wallace and Edmonds, 2011 and references herein). The $\mathrm{K}_{2} \mathrm{O} / \mathrm{Na}_{2} \mathrm{O}$ ratio of the sediment-derived trondhjemites ranges from 0.24 to 0.31 , well above that of trondhjemite produced by hydrous melting of mafic crust at sub-arc depths $\left(\mathrm{K}_{2} \mathrm{O} / \mathrm{Na}_{2} \mathrm{O}<\right.$ 0,15; Prouteau et al., 2001; Prouteau \& Scaillet, 2013). At $800^{\circ} \mathrm{C}$, melts are mostly granitic (excepted for the most sulphur-rich composition) but the $\mathrm{K}_{2} \mathrm{O} / \mathrm{Na}_{2} \mathrm{O}$ remains lower than that of the starting composition. Protracted infiltration of such low temperature melts into the overlying mantle will thus impart a more potassic character to the metasomatized mantle, compared to basalt-derived slab melts, and ultimately to arc magmas. Beyond the mica stability field, above $800^{\circ} \mathrm{C}$, and regardless the sulphur content, anatectic melts are strongly 
potassic (with $\mathrm{K}_{2} \mathrm{O} / \mathrm{Na}_{2} \mathrm{O}>2$ ) and peraluminous, unlike usual melt inclusions or pockets found in supra-subduction mantle xenoliths (e.g. Kepezhinskas et al., 1995, 1996; Schiano et al., 1995; Métrich et al., 1999; Vannucci et al., 2007; Turner et al., 2012). Partial melting of peridotite fluxed by such potassic melts could however contribute to the generation of potassic and ultrapotassic magmas in modern convergent margins (e.g. de Hoog \& van Bergen, 2000; Mallik et al., 2015).

The experimental hydrous melts show a systematic enrichment of $\mathrm{Sr}$ with respect to the starting material, suggesting that there is no residual phase capable of effectively retaining Sr. Recycling efficiencies, or mobilities, can be calculated from phase proportions and compositions in Tables 2 and 4 respectively (where mobility $=C_{i}^{\text {melt }} * \%$ melt/ $\left.C_{i}^{\text {starting composition }}\right)$. Mobilities for $\mathrm{Sr}$ are systematically $>\sim 45 \%$, and increase with temperature. Therefore, these metasomatizing melts will selectively transport $\mathrm{Sr}$ to the mantle wedge and ultimately to arc magmas.

Our experimental partition coefficients confirm that residual phengite and biotite control the Ba (with $D_{B a}^{P h / m e l t}>D_{B a}^{B t / m e l t}$ ) and $\mathrm{Rb}$ (with $D_{R b}^{B t / m e l t}>D_{R b}^{P h / m e l t}$ ) contents of the equilibrium melts as well as their $\mathrm{Rb} / \mathrm{Ba}$ ratios. At $750^{\circ} \mathrm{C}$, regardless of the bulk sulphur content, only $20-26 \%$ of the initial inventory of $\mathrm{Rb}$ and $11-22 \%$ of $\mathrm{Ba}$ are recycled by hydrous sediment melting, due to the large proportion of micas in the solid residue (Tables 2 and 4). As mica is progressively exhausted from the residue with increasing temperature, $\mathrm{Rb}$ and $\mathrm{Ba}$ concentrations in melt increase steadily and recycling is more efficient $(>55 \%$ at $800^{\circ} \mathrm{C}$ for both elements), with $\mathrm{Rb} / \mathrm{Ba}$ ratios controlled by the relative proportions of phengite and/or biotite in the residue, i.e. by the total sulphur content. At fixed temperature, adding sulphur to the system promotes biotite crystallization at the expense of phengite and therefore decreases melt $\mathrm{Rb} / \mathrm{Ba}$ ratio. Therefore, variable sulphur content of subducted pelite can contribute to the variability of $\mathrm{Rb} / \mathrm{Ba}$ ratios identified in mafic arc magmas. 
Our partial melts exhibit uniformly low $\mathrm{Ba} / \mathrm{Th}$ ratios $(30<\mathrm{Ba} / \mathrm{Th}<35$, Table 4$)$ as expected for the "sedimentary component" in IAB. At low temperature, the effects of monazite (principal host for Th) and micas (principal hosts for $\mathrm{Ba}$ ) counterbalance each other, while at high temperature no phase controls these elements anymore, hence the partial melts inherit their $\mathrm{Ba} / \mathrm{Th}$ from the starting material (Fig. 12a). Our data can, however, hardly explain the elevated $\mathrm{Ba} / \mathrm{Th}$ ratios $(\sim 100)$ observed for "sediment-flavored" arc magmas (e.g. South or Central Lesser Antilles (Fig. 13a), Aleutian, Ryuku), without the selective addition of $\mathrm{Ba}$. Local enrichment in $\mathrm{Ba}$ in the pelitic sediment should be considered. Indeed, sedimentary $\mathrm{Ba}$ concentrations can vary largely because barite $\left(\mathrm{BaSO}_{4}\right)$ controls most of the Ba budget of marine sediments (Plank \& Langmuir, 1998) and even minor quantities of barite in a sediment will have a large effect on the bulk Ba concentration. A barite-rich lithology will probably produce silicate liquids with a higher $\mathrm{Ba} / \mathrm{Th}$ ratio (and probably a lower $\mathrm{La} / \mathrm{Sm}_{\mathrm{PM}}$ ratio due to the sulphur effect, see Fig. 13a and next section) but this hypothesis clearly requires further work. We can also envision that aqueous fluids flushing the sedimentary layer are selectively enriched in soluble elements. The main source of water at sub-arc depths comes from serpentinite dehydration (e.g. Syracuse et al., 2010), and fluids produced by this process may carry some of the slab-derived trace elements. However, Ba can show little or no increase in serpentines or their associated pore fluids (Ryan \& Chauvel, 2014 and references therein). Moreover, high pressure experiments (e.g. Spandler et al., 2014) show that fluids produced by serpentinite dehydration at sub-arc depths display limited Ba concentrations $(\sim 10 \mathrm{ppm})$ and $\mathrm{Ba} / \mathrm{Th}$ fractionation $(\sim 25)$. The high $\mathrm{Ba} / \mathrm{Th}$ observed in Lesser Antilles (and other sediment-rich subduction zones) is thus best explained by the contribution of Ca-rich sediment-derived melts (Skora et al., 2015, 2017; Carpentier et al., 2009).

Sediment-poor arcs typically exhibit low LREE and Th contents and extreme $\mathrm{Ba} / \mathrm{Th}$ ratios, in excess of 1000 (Elliott, 2003; Fig. 13a). The corresponding slab component cannot 
be extracted from subducted Ca-poor pelite (this work). Ca-rich or $\mathrm{CaCO}_{3}$-rich sedimentderived melts (Skora et al., 2015, 2017) display higher Ba/Th ratios, but, as for Ca-poor sediments, their quite high LREE or Th contents can hardly explain the overall natural trend in Fig. 13a. To date, these characteristics are best explained by a fluid phase of various salinities expelled from the subducted basaltic crust by devolatilization (Green \& Adam, 2003; Kessel et al., 2005b) or hydrous melting (Carter et al., 2015). Our results reinforce therefore the difficulties of explaining arc geochemistry with a single metasomatic agent.

Finally, the post-Archean upper continental crust is enriched in alkali elements $(\mathrm{K}$, $\mathrm{Rb}$ ), compared to the Archean upper crust (e.g. Condie, 1989). Subduction of sediments derived from newly formed cratons in the late Archean and the secular increase of sediment cycling during the Phanerozoic may have contributed to the LILE inventory that ends up in the mantle wedge.

Light elements. Boron shows an incompatible behaviour in all our experiments and its calculated mobility is $>\sim 70 \%$ whatever the temperature or the sulphur content. The behaviour of $B$ is partly controlled by phengite $\left(D_{B} \sim 0.2\right.$; Table 6$)$, while it is more incompatible in biotite $\left(\mathrm{D}_{\mathrm{B}} \sim 0.05\right.$; Table 6$)$. Therefore, in the mica stability field, B recycling efficiency through Ca-poor sediment-derived melts will be enhanced by high sulphur contents.

In our experiments, the Li concentration of melt ( 70 to $130 \mathrm{ppm})$ decreases steadily with temperature, indicative of behaviour as an incompatible element with no major residual host phase (Fig. 9). At $750^{\circ} \mathrm{C}$, Li mobility increases from $\sim 36 \%$ in the S-undoped charge to $\sim 59 \%$, in the 2.1 wt. $\% \mathrm{~S}_{\text {in }}$ charge. This trend is explained by the decrease in modal garnet ( $D_{L i}^{G r t / m e l t}$ up to 0.84 , Table 5) as the sulphur content increases. For $\mathrm{T}>800{ }^{\circ} \mathrm{C}$, calculated mobility is $>80 \%$ whatever the temperature or the sulphur content. Our data show that Li is 
efficiently removed from subducted sediments via hydrous partial melting, with an enhanced efficiently at high sulphur content and high degree of partial melting.

Be concentration was below the detection limit for many glasses and silicates in our experiments, which makes interpretation of our results speculative. In the temperature range $800-1000^{\circ} \mathrm{C}, \mathrm{Be}$ concentration in the silicate melt decreases steadily with temperature (Table 4), indicative of an incompatible behaviour with no major residual host phase. At $800{ }^{\circ} \mathrm{C}$ (Sundoped run, $4 \%$ phengite in the residue), Be concentration in partial melts is of the order of $5 \mathrm{ppm}$, representing almost all the initial inventory $(\sim 2.3 \mathrm{ppm})$. Be is below the detection limit in micas in the $800{ }^{\circ} \mathrm{C}$ charges, but, nevertheless, our data suggest that phengite exerts little control on Be behaviour in the studied melting range, as already observed by Johnson \& Plank (1999). Although more work is needed, our results confirm that Be is efficiently recycled by hydrous sediment melting and that phengite complete exhaustion is not necessary to enable an effective transfer of this element (Johnson \& Plank, 1999).

\section{REE and actinides behaviour}

The concentration of REE and actinides in our experimental melts are mainly controlled by garnet (predominately HREE) and monazite (LREE and actinides).

Monazite buffers the LREE contents of melt and preferentially holds back Th and U, hosting up to $95 \%$ of LREE and Th under subsolidus conditions in Ca-poor sediments (Hermann, 2002). Monazite affects key elemental ratios ( $\mathrm{La} / \mathrm{Yb}, \mathrm{La} / \mathrm{Sm}, \mathrm{Th} / \mathrm{La}$ or $\mathrm{U} / \mathrm{Th})$ of sediment melts (e.g. Hermann \& Rubatto, 2009; Skora \& Blundy, 2010, 2012; Stepanov et al., 2012; Maimaiti et al., 2019). In our S-undoped Ca-poor sediment, monazite was identified in all charges up to $800^{\circ} \mathrm{C}$, at which melting degree is $>50 \%$. Following the method proposed by Skora \& Blundy (2010), we estimate that monazite disappears between $830^{\circ} \mathrm{C}$ and $850^{\circ} \mathrm{C}$, 
whatever the sulphur content. Because Sm was below the detection limit in the glasses produced at $750^{\circ} \mathrm{C}$ (for S-undoped run), we use $\mathrm{Nd}$ concentration and $\mathrm{Sm}$ detection limit to estimate the Sm concentration in this glass. We calculate a total LREE (Pr excluded) content of $\sim 70 \mathrm{ppm}$ in the glass of the S-undoped $750^{\circ} \mathrm{C}$ charge. In the $2.1 \mathrm{wt} . \% \mathrm{~S}_{\text {in }} 750^{\circ} \mathrm{C}$ run, the measured $\Sigma$ LREE (Pr excluded) rises to $140 \mathrm{ppm}$ (Table 4). The concentration of LREE in the melts coexisting with monazite at $800^{\circ} \mathrm{C}$ for the S-undoped experiment is $208 \mathrm{ppm}(\mathrm{Pr}$ excluded) and rises slightly to $217 \mathrm{ppm}$ in the $2.1 \mathrm{wt} . \% \mathrm{~S}_{\text {in }}$ experiment (Table 4). These results thus suggest that the LREE content in melt coexisting with monazite increases with bulk sulphur, perhaps due to complex change in major element compositions of hydrous melts as $\mathrm{S}$ increases (for example, an increase in $\mathrm{CaO}$ melt content as $\mathrm{S}$ increases could affect monazite solubility, e.g. Maimaiti et al., 2019). The significant anhydrite-celestine substitution in monazite in the sulphur-doped charges is consistent with this trend, and could have, moreover, a significant impact on the monazite/melt partition coefficients (e.g. $\left.\mathrm{D}_{\mathrm{Th}} / \mathrm{D}_{\mathrm{La}}\right)$

Effect on REE signature. The complex combined effects of monazite and garnet produces a wide range of $\mathrm{La} / \mathrm{Yb}$ ratios (Fig. 9a, Table 4): the highest ratios are observed in sulphur-poor runs (with a high proportion of garnet, which retains HREE) and beyond the monazite (which retains LREE) stability field, while monazite-saturated melts of the sulphurrich experiments show the lowest ratios (Table 4). The addition of sulphur therefore lowers LREE/HREE ratios of hydrous melts at fixed temperature. For instance, at $800^{\circ} \mathrm{C}$, the LREE/HREE in the silicate melt decreases from $\sim 74$ in sulphur-undoped run to $\sim 12$ in the 2.1 wt. $\% \mathrm{~S}_{\text {in }}$ experiment. In the same way, $\mathrm{La} / \mathrm{Sm}$ is mainly controlled by monazite (La) and garnet (Sm). Monazite-saturated melts of the sulphur-rich experiments present the lowest $\mathrm{La} / \mathrm{Sm}$, below the $\mathrm{La} / \mathrm{Sm}$ ratio in the starting sediment, (Fig. 12b, Table 4). This is mainly 
because the Sm partition coefficient for low temperature $\left(<850^{\circ} \mathrm{C}\right)$ grossular-rich garnet can be as high as 6 (Table 6), but we cannot exclude additional effects arising from either the proportion or composition of the monazite (see below). At $850^{\circ} \mathrm{C}$ (monazite out), the same effect of sulphur is observed and attributable in that case to garnet only. At 900 and $1000{ }^{\circ} \mathrm{C}$, La is not significantly fractionated from $\mathrm{Sm}$, because low $X_{\text {grossular }}$ garnet does not incorporate Sm (Table 5). Therefore Ca-poor sediment partial melts display a large range of $(\mathrm{La} / \mathrm{Sm})_{\mathrm{PM}}$ explained by the combined effect of temperature and sulphur content (Fig. 13a). This should be taken into consideration when modeling the sediment contribution to arc magmas.

Effect on $\mathrm{Th} / \mathrm{La}$. The similarity of $\mathrm{Th} / \mathrm{La}$ in subducting sediments and in the subduction component of arc magmas has led to the proposition that Th and La behave similarly during sediment recycling to the arc (Plank, 2005). For example, a maximum fractionation of $30 \%$ is observed for Lesser Antilles subduction zone (Plank, 2005). Monazite, which preferentially incorporates LREE and Th, exerts a strong control on the melt Th/LREE ratio (e.g. Hermann \& Rubatto, 2009; Skora \& Blundy, 2010, 2012; Stepanov et al., 2012). However, in previous trace elements-doped experiments, the partition coefficients for Th are either lower (e.g. Skora \& Blundy, 2010) or higher (e.g. Skora \& Blundy, 2010; Stepanov et al., 2012) than those for LREE. In our S-undoped experiment, at $750^{\circ} \mathrm{C}$, monazite-saturated melts shows their Th/La ratios increased by $60 \%$ compared to the source (Fig. 12c, Table 4). As monazite is the sole phase likely to fractionate drastically Th from La, this pattern suggests that, in our trace elements undoped experiments, $D_{T h}^{\text {monazite/melt/ }}$ $D_{L a}^{\text {monazite/melt }}$ is below unity. Interestingly, this trend is in agreement with the partition coefficients of natural monazite-peraluminous rhyolite glass pair from Macusani, Peru $\left(\mathrm{D}_{\mathrm{Th}} / \mathrm{D}_{\mathrm{La}}=0.5\right)$ (Pichavant, 1987; Montel, 1993). With 1 or 2.1 wt. \% $\mathrm{S}_{\mathrm{in}}$, this $\mathrm{Th} / \mathrm{La}$ fractionation drops to $14 \%$ (Fig. 12c, Table 4). This could be related to the higher monazite 
solubility proposed for the sulphur-rich compositions. Another possible explanation, not exclusive, is that $D_{T h}^{\text {monazite } / m e l t} / D_{L a}^{\text {monazite }} /$ melt decreases significantly for S-enriched monazite, owing to the anhydrite-celestine substitution, though our semi-quantitative analyses $\left(800^{\circ} \mathrm{C}\right)$ suggests the opposite (Table 4, Supplementary Data 3). This last point clearly requires additional work.

In hydrous melts saturated with trace amounts of monazite, at $\mathrm{T}=800^{\circ} \mathrm{C}$, the sourcenormalized $\mathrm{Th} / \mathrm{La}$ is $\approx 1$, regardless of sulphur content (Fig. 12c). The same trend is observed once monazite is exhausted from the residue $\left(\mathrm{T}>850^{\circ} \mathrm{C}\right)$. Therefore, our results suggest that minor residual monazite in the subducted sediments will not significantly affect the $\mathrm{Th} / \mathrm{La}$ of the coexisting melt. There is no need for monazite to be completely consumed in order to transfer the $\mathrm{Th} / \mathrm{La}$ ratio of sediments into arc magmas, as previously suggested by Stepanov et al. (2012). We speculate also that S-rich conditions will favor a low fractionation of LREE relative to $\mathrm{Th}$, for the lowest temperatures.

The sediment signal in arc magmas is moreover characterized by a selective enrichment in LREE and Th abundances. At $750^{\circ} \mathrm{C}$, the transport capacity of LREE and Th is relatively low in sulphur-poor (S-undoped) compositions (mobilities of $8 \%$ and $13 \%$ for La and Th, respectively), but rises to more than $20 \%$ for both elements in the $2.1 \mathrm{wt} . \% \mathrm{~S}_{\text {in }}$ charges. At $800^{\circ} \mathrm{C}$ and above, mobilities are uniformly high ( $\left.>50 \%\right)$. Therefore, partial melts of subducted Ca-poor sediments with residual monazite for sulphur-rich conditions $\left(\mathrm{S}_{\mathrm{in}}=2.1\right.$ wt. $\%$ ) at $750^{\circ} \mathrm{C}$, or at $800^{\circ} \mathrm{C}$ and above whatever $\mathrm{S}$ content, are in agreement with the observed $\mathrm{Th}$ and $\mathrm{La}$ abundances and $\mathrm{Th} / \mathrm{La}$ systematics in sediment-rich arc magmas.

Effect on U/Th. The fractionation of $\mathrm{U}$ from Th in Ca-poor sediments is mainly controlled by monazite and, to a lesser extent, garnet and zircon. The $750^{\circ} \mathrm{C}$ monazitesaturated hydrous melts show a source-normalized U/Th well above unity (Fig. 12d). This is 
because $D_{T h}^{\text {monazite/melt }}$ is approximately 20 times greater than $D_{U}^{\text {monazite/melt }}$ (Skora \& Blundy, 2010; Stepanov et al., 2012). Sulphur impact on U/Th fractionation is moreover noticeable at this temperature: the U/Th ratio increases by $>30 \%$ compared to the starting sediment in the S-undoped charge and this increase is $>50 \%$ in the 2.1 wt. $\% \mathrm{~S}_{\text {in }}$ charge (Fig. 12d, Table 4). As $D_{U}^{G r t / m e l t}>D_{T h}^{G r t / m e l t}$ (Table 5), then this effect could probably be partly related to the decrease of residual garnet with increasing sulphur content. However, the impact of sulphur at fixed $\mathrm{T}$ is negligible $(<2 \mathrm{wt} . \%)$ at $800^{\circ} \mathrm{C}$, with trace amounts of monazite, or once monazite is exhausted $\left(\mathrm{T}>850^{\circ} \mathrm{C}\right.$ ) (Fig. 12d, Table 4). We therefore postulate that the proportion and/or composition (with $\mathrm{D}_{\mathrm{Th}} / \mathrm{D}_{\mathrm{U}}$ in S-rich monazite $>\mathrm{D}_{\mathrm{Th}} / \mathrm{D}_{\mathrm{U}}$ in S-poor monazite) of residual S-rich monazite mainly control the trend observed at $750^{\circ} \mathrm{C}$. At $800^{\circ} \mathrm{C}$, where monazite occurs in trace amounts, or beyond the monazite stability field, Th and U are not significantly fractionated, whatever the sulphur content. The slight uranium excess observed at $\mathrm{T}>850^{\circ} \mathrm{C}$ (Fig. 12d) may be due to the presence of carbonates $\left(D_{U}^{\text {carbonate } / \text { melt }}<D_{T h}^{\text {carbonate } / \text { melt }}\right)$, identified in trace amounts at high temperature, which probably counteracts the effect of garnet and zircon $\left(D_{U}^{\text {zircon } / \text { melt }}>D_{T h}^{\text {zircon } / \text { melt }}\right.$ in the explored $f \mathrm{O}_{2}$ range, Burnham \& Berry, 2012).

Our results show that $\mathrm{U}$ excess is achieved in Ca-poor sediments partial melts, with larger excess observed at low temperature and sulphur-rich conditions. At low temperatures, this signature is controlled by the proportion and composition of the accessory phases, which depends in turn on the composition of the sediment. For instance, apatite-saturated partial melts expelled from volcaniclastic sediments will have slight Th excess (Martindale et al., 2013), a signature never produced in our composition. Thus, as already noticed by previous authors (e.g. Hermann \& Rubatto, 2009), care has to be taken when the nature of the slab fluid phase is determined from such an isotopic signal alone. U-Th systematics of arc lavas best 
reflect the contrasting solubilities of accessory phases in subduction zones with different thermal and compositional controls.

Altogether, our results show that melts expelled from Ca-poor sediments variously enriched in sulphur can explain the overall U/Th vs Th trend for most sediment-rich lavas (Fig. 13b) but can hardly account for the extreme $\mathrm{U}$ enrichment (associated with low Th concentrations) characteristic of some sediment-poor arcs (Fig. 13b). These arcs require another source than Ca-poor sediments for $\mathrm{U}$ efflux from subducted materials, as already discussed above for Ba enrichment.

Recycling of Ca-poor sediment in subduction zones and the HFSE cycle

$\mathrm{Nb}$ and Ta signature of pelite melts. As rutile is a major host of HFSE such as Ti, $\mathrm{Nb}$, and $\mathrm{Ta}$, the solubility of rutile is the key to the HFSE concentrations of hydrous silicic melts from the subducting sediment. Moreover, rutile preferentially incorporates $\mathrm{Ta}$ over $\mathrm{Nb}$ during hydrous melting, with $\mathrm{D}_{\mathrm{Nb}} / \mathrm{D}_{\mathrm{Ta}}<1$ (Schmidt et al., 2004a; Klemme et al., 2005; Xiong et al., 2011). Xiong et al. (2011) have shown that, in the range $1.5-3.5 \mathrm{GPa}$ and $900-1350^{\circ} \mathrm{C}$, temperature and melt water content have marked effects on partition coefficients for felsic melts $\left(\mathrm{D}_{\mathrm{Nb}}, \mathrm{D}_{\mathrm{Ta}}\right.$ and $\mathrm{D}_{\mathrm{Nb}} / \mathrm{D}_{\mathrm{Ta}}$ increase with decreasing temperature and water content), whereas pressure and melt composition do not.

The hydrous felsic melts produced in our experiments are all saturated in rutile. Whatever the temperature or sulphur content, $\mathrm{Ti}, \mathrm{Nb}$ and $\mathrm{Ta}$ show negative anomalies relative to LILE and are depleted with respect to the starting material (Fig. 9a). (Th/Nb) $)_{\mathrm{N}}$ is also systematically above 1 in our experiments (Fig. 12e). Therefore, our experiments fulfill the constraint that the slab component in the source of the enriched arc lavas exhibits higher $\mathrm{Th} / \mathrm{Nb}$ than the subducting sediment (Elliott, 2003). In detail, $(\mathrm{Th} / \mathrm{Nb})_{\mathrm{N}}$ increases from $750^{\circ} \mathrm{C}$ 
to $800^{\circ} \mathrm{C}$ (except for the more S-rich run with $\mathrm{S}_{\mathrm{in}}=2.1 \mathrm{wt}$. \%) owing to increasing monazite dissolution. At $800^{\circ} \mathrm{C}$ the fractionation is clearly more pronounced in the S-undoped charge, owing to the presence of phengite which incorporates $\mathrm{Nb}$ (Fig. 10c); the $(\mathrm{Th} / \mathrm{Nb})_{\mathrm{N}}$ ratio then decreases at $850^{\circ} \mathrm{C}$ because of the $\mathrm{Nb}$ contribution from phengite breakdown (in addition to increasing rutile contribution). Beyond the stability field of monazite, $(\mathrm{Th} / \mathrm{Nb})_{\mathrm{N}}$ decreases steadily with temperature, whatever the sulphur content: more and more rutile is dissolved into the hydrous melt during the hydrous partial melting of subducting metapelite at subarc depths, more HFSE are delivered to the mantle sources of arc magmas.

All analysed melts show sub-chondritic $\mathrm{Nb} /$ Ta ratios (Table 4) and fractionation of $\mathrm{Nb} /$ Ta relative to their sediment precursor, but the fractionation direction and magnitude depend, primarily, on temperature (Fig. 12f) and sulphur content. Whatever the sulphur content, $(\mathrm{Nb} / \mathrm{Ta})_{\mathrm{N}}$ increases drastically from $750^{\circ} \mathrm{C}$ to $900^{\circ} \mathrm{C}$ (Fig. 12f). The elevated $\mathrm{Nb} / \mathrm{Ta}$ at $900^{\circ} \mathrm{C}$ is best explained by the preferential incorporation of Ta over $\mathrm{Nb}$ in residual rutile (Schmidt et al., 2004a; Klimm et al., 2008; Hermann \& Rubatto, 2009). To test this hypothesis, we used the empirical expression derived by Xiong et al. (2011) to estimate $D_{N b}^{\text {rutile/melt } /} D_{T a}^{\text {rutile/melt }}$ in our experiments. Calculated $D_{N b}^{\text {rutile/melt } /} D_{T a}^{\text {rutile/melt }}$ vary from 0.6 to 1.0 , depending on temperature and melt water content. Therefore, hydrous melting at high temperature, in the presence of residual rutile and without any other phase capable of fractionating significantly $\mathrm{Nb}$ and $\mathrm{Ta}$, should result in melts with constant or higher $\mathrm{Nb} / \mathrm{Ta}$ when compared to the starting sediment, i.e. a trend at variance with the sub-chondritic $\mathrm{Nb} / \mathrm{Ta}$ ratio of arc magmas. In contrast, low temperature $\left(750^{\circ} \mathrm{C}\right)$ melts in equilibrium with phengite (S-undoped) or phengite + biotite $\left(1\right.$ wt. $\left.\% \mathrm{~S}_{\text {in }}\right)$ exhibit lower $\mathrm{Nb} /$ Ta ratios than the starting sediment. At $800^{\circ} \mathrm{C}$ and 2.1 wt. $\% \mathrm{~S}_{\text {in }}$, with only biotite in the residue, $(\mathrm{Nb} / \mathrm{Ta})_{\mathrm{N}}$ is close to 1 , suggesting that biotite alone can hardly counteracts the rutile effect. In agreement with previous studies (Nash \& Crecraft, 1985; Acosta-Vigil et al., 2010; Stepanov \& Hermann, 
2013), our results suggest that low temperature residual phengite in equilibrium with felsic melt preferentially incorporates $\mathrm{Nb}$ over Ta. Our results thus extend Stepanov \& Hermann's (2013) findings to lower temperatures, suggesting that even Ti-poor phengites (0.5-1.2 wt. \% $\mathrm{TiO}_{2}$, Supplementary Data 3) may significantly fractionate $\mathrm{Nb}$ and Ta. Therefore, in the phengite stability field, the rutile effect can be counterbalanced and melting reduces $\mathrm{Nb} / \mathrm{Ta}$ relative to the sediment precursor.

The above inferences suggest that high pressure hydrous melting of terrigenous sediments in Phanerozoic subduction zones might be an important process to produce $\mathrm{Nb}$ poor melt with sub-chondritic $\mathrm{Nb} / \mathrm{Ta}$. Phanerozoic arc magmas and continental crust may inherit their sub-chondritic $\mathrm{Nb} / \mathrm{Ta}$ ratios from a source metasomatized, inter alia, by these hydrous felsic melts, derived from the top sedimentary layer of the downgoing slab. This process also produces $\mathrm{Nb}$-rich restites with super-chondritic $\mathrm{Nb} / \mathrm{Ta}$, that could represent one of the missing reservoirs to balance the sub-chondritic $\mathrm{Nb} / \mathrm{Ta}$ of the upper crust and the depleted mantle, as already suggested by Stepanov \& Hermann (2013).

Whether $\mathrm{Nb} / \mathrm{Ta}$ fractionation of crustal rocks is a modern process or was already operating during Archean times is unclear. Archean tonalites-trondhjemites-granites (TTGs) represent the oldest felsic continental crust. These felsic, sodic magmas are widely accepted to be the products of partial melting of hydrous metabasalt at pressures sufficiently high to stabilize garnet (e.g. Moyen, 2011). There remains however considerable controversy surrounding the geodynamic setting, some considering that TGGs formed mainly by partial melting of subducting oceanic lithosphere (e.g. Martin, 1986; Drummond et al., 1996) and other favoring TTGs formation at the base of thick, plateau-like basaltic crust (e.g. Smithies et al., 2003; Johnson et al., 2017, 2019). Recent analyses of $\mathrm{Nb} / \mathrm{Ta}$ in Eoarchean and Mesoarchean TTG associations have shown that these display highly variable $\mathrm{Nb} / \mathrm{Ta}$ ratios of 7-27 (Hoffmann et al., 2011). Even larger fractionations were observed in Archean migmatitic 
TTGs, with $\mathrm{Nb} / \mathrm{Ta}$ ratios ranging from 14 to 42 with a strongly super-chondritic average $\mathrm{Nb} / \mathrm{Ta}$ of 29 (Xiong et al., 2011; Stepanov \& Hermann, 2013; Li et al., 2017). These scattered and super-chondritic ratios are best explained by hydrous melting of rutile-bearing eclogites, if the average $\mathrm{Nb} / \mathrm{Ta}$ ratio of the Archean mantle and MORB (Jochum et al., 2001) are accepted. In particular, the very high $\mathrm{Nb} / \mathrm{Ta}$ ratios of some $\mathrm{TTG}$ rocks relative to the average Archean MORB can only be explained by low degree partial melting in the presence of both rutile and a hydrous fluid (Foley et al., 2002; Xiong et al., 2011). Therefore, as insightfully suggested by Green (1995), Archean gneisses may be a complementary component to that part of continental crust which has a relatively low $\mathrm{Nb} / \mathrm{Ta}$.

Sedimentary cycling during the Archean is widely discussed. Isotopic studies (massindependent $\mathrm{S}$ isotopic fractionation, $\mathrm{Ce}-\mathrm{Nd}$ isotopes) suggest recycling of surface materials in a reduced atmosphere before the Great Oxygenation Event, which happened at about 2.4 Ga ago (Cabral et al., 2013; Delavault et al., 2016; Israel et al., 2020). Several authors have proposed (on the basis of isotope data for $\mathrm{Hf}, \mathrm{O}, \mathrm{Si}$ ) that Archean juvenile continental crust formed by melting of enriched mafic crust extracted from a still primitive mantle, and that sediment recycling occurred only since the Mesoarchean (e.g. Næraa et al., 2012; Reimink et al., 2016; Roberts \& Santosh, 2018; Trail et al., 2018; Smit et al., 2019). Moreover, Rey \& Coltice (2008) have proposed that during the Archean, the continental crust, covered by continental flood basalt, and with low surface elevation and low erosion level, has been isolated from other geochemical reservoirs. Their numerical experiments suggest that the relative isolation of the felsic continental crust may have ended during the Neoarchean, when the strengthening of the continental lithosphere allowed for the development of significant topography. The subsequent erosion and exhumation of felsic crust would have led to coupling of the continental reservoir with the mantle reservoirs. These observations suggest that deep cycling of surface-altered rocks was restricted to post-Neoarchean times when 
recycling of such material, possibly by subduction, became prevalent (Valley et al., 2005; Rey $\&$ Coltice, 2008).

The above considerations lead us to conclude that the $\mathrm{Nb}$ /Ta deficit (together with LILE enrichment) is a post-Archean feature, reflecting the secular increase in terrigenous, $\mathrm{K}$ rich sediments recycling in the subduction factory.

The role of zircon: $\mathrm{Zr}$ and $\mathrm{Hf}$ signature of pelite-melts. In our experiments, $\mathrm{Zr}$ is hosted mainly in zircon, and, to a lesser extent, in garnet (Fig. 10a, Table 5; Rubatto, 2002; Rubatto \& Hermann, 2007). Our study shows that zircon persists up to $1000^{\circ} \mathrm{C}$ and to high degree of partial melting $(>70 \%)$ in the studied starting material. Residual garnet decreases drastically with sulphur addition, at fixed temperature. $\mathrm{Zr}$ and $\mathrm{Hf}$ concentrations increase steadily with temperature in our experimental melts, a trend consistent with increasing solubility of zircon at higher temperature. The negative $\mathrm{Zr}$ anomaly of the starting product is preserved $\left(1000^{\circ} \mathrm{C}\right)$ or amplified $\left(\mathrm{T}<900^{\circ} \mathrm{C}\right)$ in the entire melting interval (Fig. $\left.12 \mathrm{~g}\right)$. At $800^{\circ} \mathrm{C}$, Hf concentration in the partial melt is around 2-3 ppm representing $24 \%$ (sulphurundoped) to $28 \%\left(2.1\right.$ wt. $\left.\% \mathrm{~S}_{\text {in }}\right)$ of the initial inventory. These mobilities are of the same order of magnitude as the estimates for the Izu-Mariana arc (Chauvel et al., 2009), and support the hypothesis that the Hf isotopic signature of arc lavas might be related to the addition of sediment melts.

Zircon (Linnen \& Keppler, 2002; Rubatto \& Hermann, 2007) and garnet (D $\mathrm{Zr}$ rrtmelt/ $\mathrm{D}_{\mathrm{Hf}}^{\mathrm{Grt} / \mathrm{melt}} \sim 1.3-1.9$; Table 5) are able to fractionate the geochemical twins $\mathrm{Zr}$ and Hf. At fixed $\mathrm{S}_{\mathrm{in}}, \mathrm{Zr} / \mathrm{Hf}$ ratio increases with increasing temperature, providing new evidence that the melt $\mathrm{Zr}$ and $\mathrm{Hf}$ are controlled by small amounts of zircon (Fig. $12 \mathrm{~h}$ ). For $\mathrm{T}<900^{\circ} \mathrm{C}$, the subchondritic $\mathrm{Zr} / \mathrm{Hf}$ ratio of the starting material is preserved or amplified by partial melting, except for the more sulphur-rich run (Fig. 12h). Although data overlap when their 
uncertainties are considered (especially at 800 and $900^{\circ} \mathrm{C}$ ), the mean $\mathrm{Zr} / \mathrm{Hf}$ ratio tends to increase with the sulphur content at fixed temperature (e.g. compare 0 and 2.1 wt. $\% \mathrm{~S}_{\text {in }}$ runs at $850^{\circ} \mathrm{C}$, Fig. $12 \mathrm{~h}$ ). It can be inferred that $\mathrm{Zr}-\mathrm{Hf}$ fractionation is probably partly garnetinduced and thus affected by $\mathrm{S}$. The effect of sulphur is much more significant on HREE/Hf ratios, due to high $D_{H R E E}^{G r t / m e l t}$ (Table 5). For example, at $900^{\circ} \mathrm{C}$, the $\mathrm{Yb} / \mathrm{Hf}$ ratio is multiplied by $\sim 10$ when 2.1 wt. \% sulphur is added (Table 4). Therefore the Lu/Hf, $\mathrm{Zr} / \mathrm{Hf}$ and $\mathrm{Hf}$ isotope systematics usually used to track sediment contribution to the arc magmatism (e.g. Nebel et al., 2011) is sensitive not only to slab surface temperature, but also, albeit to a lesser extent, to the sulphur content of the subducted sediments.

\section{Pb transfer to the mantle wedge}

We exclude experiments performed at $\mathrm{T} \geq 850^{\circ} \mathrm{C}$ from this discussion because of $\mathrm{Pb}$ contamination suspected at high temperature. $\mathrm{Pb}$ is incompatible in the $750-800^{\circ} \mathrm{C}$ experiments, whatever the sulphur content (Table 4). $\mathrm{Pb}$ is more incompatible than $\mathrm{Ce}$, and the ratio $(\mathrm{Ce} / \mathrm{Pb})_{\mathrm{N}}$ is systematically $<1$ (Fig. 12i). The fractionation is maximum in charges saturated with high modal monazite $\left(750^{\circ} \mathrm{C}\right)$, which selectively incorporates LREE. Sulphur content has no significant effect on the partitioning of $\mathrm{Pb}$, implying counter-intuitively that sulphide minerals are not an important carrier of $\mathrm{Pb}$. At $800^{\circ} \mathrm{C}\left(2.1\right.$ wt. \% $\left.\mathrm{S}_{\text {in }}\right)$, pyrrhotite $(4.8$ wt. $\%$ in the run products, Table $2 ; \mathrm{D}_{\mathrm{P}}^{\text {pyrrhotite/melt }} \sim 0.4$, Table 8 ) sequesters only around $4 \%$ of the initial inventory of $\mathrm{Pb}(=22.4 \mathrm{ppm}$, Table 4$)$. Therefore, our data show that low temperature $\mathrm{Ca}$-poor sediment-derived melt can contribute to the $\mathrm{Ce} / \mathrm{Pb}$ ratio typical of arc magmas, even for sulphur-rich bulk compositions.

As already stressed, abundant evidence support that the $\mathrm{Ce} / \mathrm{Pb}$ evolution in the mantle is controlled by subduction processes. Quantitative models for the $\mathrm{Ce} / \mathrm{Pb}$ evolution of the mantle 
and crust generally assume $\mathrm{Pb}$ loss from the subducted slab mainly through low $\mathrm{Ce} / \mathrm{Pb}$ hydrous fluids (e.g. Kelley et al., 2005). Although this point needs clearly further work and is beyond the scope of this study, the secular increase in terrigenous sediments recycling since the Mesoarchean may have contributed to the pervasive depletion of lead in the oceanic mantle. Similarly, our results show that, at low temperature, $\mathrm{Pb}$ is extracted 1.5 to 3.5 times more than $\mathrm{U}$ by hydrous melt from Ca-poor sediment (i.e. $\left[\mathrm{Pb} / \mathrm{U}_{\text {melt }}\right] /\left[\mathrm{Pb} / \mathrm{U}_{\text {sediment }}\right] \sim 1.5$ at $800^{\circ} \mathrm{C}$ and $\sim 2$ to 3.5 at $750{ }^{\circ} \mathrm{C}$, Table 4). Preferential $\mathrm{Pb}$ loss from sediment (together from AOC, the key flux in accounting for U cycle, e.g. Kelley et al., 2005) will increase $\mu$ (with $\mu=\mathrm{U} / \mathrm{Pb})$ in the slab residue and therefore potentially contribute to the HIMU mantle component identified in OIB (Ocean Island Basalt) source. Elemental and isotope systematics of $\mathrm{U}$ in OIB indicate formation of this mantle reservoir between 2.5 and $1.8 \mathrm{Ga}$ (Andersen et al., 2015).

\section{CONCLUDING REMARKS}

We have investigated phase equilibrium and trace element partitioning for hydrous Ca-poor sediments at sub-arc conditions $\left(750-1000^{\circ} \mathrm{C}, 3 \mathrm{GPa}\right)$. We explored the effect of bulk sulphur content (from 900 ppm to 2.2 wt. \%) at various $f \mathrm{O}_{2}$ on high pressure phase stabilities and compositions. The addition of elemental sulphur decreases effective bulk Fe and this has an impact on both phase compositions (e.g. high $\mathrm{X}_{\mathrm{Mg}}$ of ferro-magnesian major silicate phases) and stabilities (e.g. breakdown of garnet to orthopyroxene, breakdown of phengite to biotite). The composition and solubility of a key accessory phase such as monazite could be also affected by the bulk S-content (S-component substitution in monazite). 
Our results confirm previous suggestions that sediment-derived hydrous melts can exhibit high sulphur contents, and then contribute to the S-rich character of Phanerozoic arc magmas, provided that high $f \mathrm{O}_{2}$ and/or high $\mathrm{S}$ content in the source prevail.

The enrichment or depletion of trace elements in the experimental sediment melts exhibit features similar to the sediment-derived slab component of arc lavas (e.g. La/Sm, $\mathrm{Th} / \mathrm{La}, \mathrm{Th} / \mathrm{Nb}, \mathrm{Nb} / \mathrm{Ta}, \mathrm{Ce} / \mathrm{Pb}$ ratios). In agreement with previous studies, our work emphasizes the importance of residual mineralogy in controlling the trace element characteristics of sediment-derived melts. The sediment signature, including Th and $\mathrm{Be}$ effective transport, is enhanced in the phengite stability field at $750{ }^{\circ} \mathrm{C}$ (provided high $\mathrm{S}$ content) or $800^{\circ} \mathrm{C}$. This temperature range corresponds roughly to slab-top estimates from recent subduction models.

On the other hand, our study shows that Ca-poor sediment-derived melts cannot explain the large U or Ba enrichments typical of "sediment-starved" arcs. These arcs require another source (fluids expelled from serpentinite, $\mathrm{AOC}$ ) for $\mathrm{U}$ and $\mathrm{Ba}$, which supports the tripartite model of arc source.

Finally, the secular increase in terrigenous sediment recycling since the Mesoarchean could have contributed to the evolution of the composition of continental crust with time (e.g. enrichment in LILE, decreasing $\mathrm{Nb} / \mathrm{Ta}$ ). The long-term recycling of sedimentary material will also contribute to the chemical heterogeneity in the terrestrial mantle (e.g. $\mathrm{Ce} / \mathrm{Pb}, \mathrm{U} / \mathrm{Pb}$ ).

\section{ACKNOWLEDGMENTS}

We thank Ida Di Carlo and Patricia Benoist for assistance with EMPA and SEM, Jean-Luc Devidal and Bernard Gratuze for assistance with LA-ICP-MS and Yann Morizet and Aneta 
Slodczyk for assistance with Raman spectroscopy. We thank Laura Airaghi for the Perple_X calculations.

The paper greatly benefited from constructive reviews by Yuan Li, Andrew Tomkins and Jesse Walters, and the careful editorial handling of Andreas Audétat and Georg Zellmer.

\section{FUNDING}

This work was supported by LabEx VOLTAIRE (LABX-100-01) and EquipEx PLANEX (ANR-11-EQPX-0036) projects and by grants from INSU - TellusS - SYSTER.

\section{REFERENCES}

Acosta-Vigil, A., Buick, I., Hermann, J., Cesare, B., Rubatto, D., London, D. \& Morgan, G. B. (2010). Mechanisms of Crustal Anatexis: a Geochemical Study of Partially Melted Metapelitic Enclaves and Host Dacite, SE Spain. Journal of Petrology. Oxford Academic 51, 785-821.

Albarède, F. (1995). Introduction to Geochemical Modeling. Cambridge University Press.

Alt, J. C. \& Burdett, J. W. (1992). Sulfur in Pacific deep-sea sediments (Leg 129) and implications for cycling of sediment in subduction zones. In : Proc. ODP, Sci. Results. College Station, TX (Ocean Drilling Program) 129, 283-294.

Andersen, M. B., Elliott, T., Freymuth, H., Sims, K. W. W., Niu, Y. \& Kelley, K. A. (2015). The terrestrial uranium isotope cycle. Nature. Nature Publishing Group 517, 356-359.

Auzanneau, E., Vielzeuf, D. \& Schmidt, M. W. (2006). Experimental evidence of decompression melting during exhumation of subducted continental crust. Contributions to Mineralogy and Petrology 152, 125-148.

Ayers, J. C., Watson, E. B., Tarney, J., Pickering, K. T., Knipe, R. J. \& Dewey, J. F. (1991). Solubility of apatite, monazite, zircon, and rutile in supercritical aqueous fluids with implications for subduction zone geochemistry. Philosophical Transactions of the Royal Society of London. Series A: Physical and Engineering Sciences. Royal Society 335, $365-375$. 
Ballèvre, M., Pinardon, J.-L., Kienast, J.-R. \& Vuichard, J.-P. (1989). Reversal of Fe-Mg Partitioning Between Garnet and Staurolite in Eclogite-facies Metapelites from the Champtoceaux Nappe (Brittany, France). Journal of Petrology 30, 1321-1349.

Barth, M. G., McDonough, W. F. \& Rudnick, R. L. (2000). Tracking the budget of Nb and Ta in the continental crust. Chemical Geology 165, 197-213.

Bénard, A., Klimm, K., Woodland, A.B., Arculus, R.J., Wilke, M., Botcharnikov, R.E., Shimizu, N., Nebel, O., Rivard, C. \&. Ionov, D.A. (2018). Oxidising agents in sub-arc mantle melts link slab devolatilisation and arc magmas. Nature Communications 9, 110.Binder, B. \& Keppler, H. (2011). The oxidation state of sulfur in magmatic fluids. Earth and Planetary Science Letters 301, 190-198.

Borisova, A. Y., Toutain, J.-P., Dubessy, J., Pallister, J., Zwick, A. \& Salvi, S. (2014). $\mathrm{H}_{2} \mathrm{O}-$ $\mathrm{CO}_{2}-\mathrm{S}$ fluid triggering the 1991 Mount Pinatubo climactic eruption (Philippines). Bulletin of Volcanology 76, 800.

Bouvier, A.-S., Métrich, N. \& Deloule, E. (2008). Slab-Derived Fluids in the Magma Sources of St. Vincent (Lesser Antilles Arc): Volatile and Light Element Imprints. Journal of Petrology. Oxford Academic 49, 1427-1448.

Brenan, J. M., Shaw, H. F. \& Ryerson, F. J. (1995). Experimental evidence for the origin of lead enrichment in convergent-margin magmas. Nature 378, 54-56.

Brown, J. L., Christy, A. G., Ellis, D. J. \& Arculus, R. J. (2014). Prograde Sulfide Metamorphism in Blueschist and Eclogite, New Caledonia. Journal of Petrology. Oxford Academic 55, 643-670.Burnham, A. D. \& Berry, A. J. (2012). An experimental study of trace element partitioning between zircon and melt as a function of oxygen fugacity. Geochimica et Cosmochimica Acta 95, 196-212.

Cabral, R. A., Jackson, M. G., Rose-Koga, E. F., Koga, K. T., Whitehouse, M. J., Antonelli, M. A., Farquhar, J., Day, J. M. D. \& Hauri, E. H. (2013). Anomalous sulphur isotopes in plume lavas reveal deep mantle storage of Archaean crust. Nature. Nature Publishing Group 496, 490-493.

Canfield, D. E. (2004). The evolution of the Earth surface sulfur reservoir. American Journal of Science. American Journal of Science 304, 839-861.

Canil, D. \& Fellows, S. A. (2017). Sulphide-sulphate stability and melting in subducted sediment and its role in arc mantle redox and chalcophile cycling in space and time. Earth and Planetary Science Letters 470, 73-86.

Carpentier, M. (2007). Composition chimique des sédiments entrant dans la zone de subduction des Petites Antilles. Phd thesis, Université Joseph-Fourier - Grenoble I. 
Carpentier, M., Chauvel, C. \& Mattielli, N. (2008). Pb-Nd isotopic constraints on sedimentary input into the Lesser Antilles arc system. Earth and Planetary Science Letters 272, 199-211.

Carpentier, M., Chauvel, C., Maury, R. C. \& Mattielli, N. (2009). The "zircon effect" as recorded by the chemical and Hf isotopic compositions of Lesser Antilles forearc sediments. Earth and Planetary Science Letters 287, 86-99.

Carroll M. R. \& Rutherford M. J. (1985). Sulfide and sulfate saturation in hydrous silicate melts. Journal of Geophysical Research 90, 601-612.

Carroll, M. R. \& Rutherford, M. J. (1987). The Stability of Igneous Anhydrite: Experimental Results and Implications for Sulfur Behavior in the 1982 El Chichon Trachyandesite and Other Evolved Magmas. Journal of Petrology 28, 781-801.

Carroll, M. R. \& Webster, J. D. (1994). Solubilities of sulfur, noble gases, nitrogen, chlorine, and fluorine in magmas. In : Holloway, J.R. \& Carroll, M.R. (eds.). Volatiles in Magmas. Mineral. Soc. Amer., 231-280.

Carter, L. B., Skora, S., Blundy, J. D., De Hoog, J. C. M. \& Elliott, T. (2015). An Experimental Study of Trace Element Fluxes from Subducted Oceanic Crust. Journal of Petrology 56, 1585-1606.

Cervantes, P. \& Wallace, P. J. (2003). Role of $\mathrm{H}_{2} \mathrm{O}$ in subduction-zone magmatism: New insights from melt inclusions in high-Mg basalts from central Mexico. Geology 31, $235-238$.

Chakhmouradian, A. R. \& Mitchell, R. H. (1999). Niobian ilmenite, hydroxylapatite and sulfatian monazite; alternative hosts for incompatible elements in calcite kimberlite from Internatsional'naya, Yakutia. The Canadian Mineralogist 37, 1177-1189.

Chauvel, C., Goldstein, S. L. \& Hofmann, A. W. (1995). Hydration and dehydration of oceanic crust controls $\mathrm{Pb}$ evolution in the mantle. Chemical Geology 126, 65-75.

Chauvel, C., Marini, J.-C., Plank, T. \& Ludden, J. N. (2009). Hf-Nd input flux in the IzuMariana subduction zone and recycling of subducted material in the mantle.

Geochemistry, Geophysics, Geosystems 10, Q01001.

Chen, Y.-X., Zheng, Y.-F., Chen, R.-X., Zhang, S.-B., Li, Q., Dai, M. \& Chen, L. (2011). Metamorphic growt.h and recrystallization of zircons in extremely ${ }^{18} \mathrm{O}$-depleted rocks during eclogite-facies metamorphism: Evidence from $\mathrm{U}-\mathrm{Pb}$ ages, trace elements, and O-Hf isotopes. Geochimica et Cosmochimica Acta 75, 4877-4898.

Chester, R. (1990). Marine sediments. In: Chester, R. (ed.) Marine Geochemistry. Dordrecht: Springer Netherlands, 441-467. 
Class, C., Miller, D. M., Goldstein, S. L. \& Langmuir, C. H. (2000). Distinguishing melt and fluid subduction components in Umnak Volcanics, Aleutian Arc. Geochemistry, Geophysics, Geosystems 1, 1004.

Clemente, B., Scaillet, B. \& Pichavant, M. (2004). The Solubility of Sulphur in Hydrous Rhyolitic Melts. Journal of Petrology 45, 2171-2196.

Condie, K. C. (1989). Geochemical changes in baslts and andesites across the ArcheanProterozoic boundary: Identification and significance. Lithos 23, 1-18.

Condomines, M. \& Sigmarsson, O. (1993). Why are so many arc magmas close to 238U230Th radioactive equilibrium? Geochimica et Cosmochimica Acta 57, 4491-4497.

Connolly, J. A. D. \& Galvez, M. E. (2018). Electrolytic fluid speciation by Gibbs energy minimization and implications for subduction zone mass transfer. Earth and Planetary Science Letters 501, 90-102.

Costa, F., Scaillet, B. \& Pichavant, M. (2004). Petrological and Experimental Constraints on the Pre-eruption Conditions of Holocene Dacite from Volcán San Pedro (36 ${ }^{\circ} \mathrm{S}$, Chilean Andes) and the Importance of Sulphur in Silicic Subduction-related Magmas. Journal of Petrology 45, 855-881.

de Hoog, J. C. M., Mason, P. R. D. \& van Bergen, M. J. (2001a). Sulfur and chalcophile elements in subduction zones: constraints from a laser ablation ICP-MS study of melt inclusions from Galunggung Volcano, Indonesia. Geochimica et Cosmochimica Acta 65, 3147-3164.

de Hoog, J. C. M., Taylor, B. E. \& van Bergen, M. J. (2001b). Sulfur isotope systematics of basaltic lavas from Indonesia: implications for the sulfur cycle in subduction zones. Earth and Planetary Science Letters 189, 237-252.

de Hoog, J. C. M. \& van Bergen, M. J. (2000). Volatile-induced transport of HFSE, REE, Th and $U$ in arc magmas: evidence from zirconolite-bearing vesicles in potassic lavas of Lewotolo volcano (Indonesia). Contributions to Mineralogy and Petrology 139, 485502.

Deer, W. A. (1962). Rock Forming Minerals. Sheet Silicates 3. Wiley.

Delavault, H., Chauvel, C., Thomassot, E., Devey, C. W. \& Dazas, B. (2016). Sulfur and lead isotopic evidence of relic Archean sediments in the Pitcairn mantle plume. Proceedings of the National Academy of Sciences 113, 12952-12956.

Devine, J. D., Gardner, J. E., Brack, H. P., Laynet, G. D. \& Rutherford, M. J. (1995). Comparison of microanalytical methods for estimating $\mathrm{H}_{2} \mathrm{O}$ contents of silicic volcanic glasses. American Mineralogist 80, 319-328. 
Drummond, M. S., Defant, M. J. \& Kepezhinskas, P. K. (1996). Petrogenesis of slab-derived trondhjemite-tonalite-dacite/adakite magmas. Earth and Environmental Science Transactions of The Royal Society of Edinburgh. Royal Society of Edinburgh Scotland Foundation 87, 205-215.

D’Souza, R. J. \& Canil, D. (2018). The partitioning of chalcophile elements between sediment melts and fluids at $3 \mathrm{GPa}, 950-1050^{\circ} \mathrm{C}$ with implications for slab fluids in subduction zones. Earth and Planetary Science Letters 498, 215-225.

Ellam, R. M. \& Hawkesworth, C. J. (1988). Elemental and isotopic variations in subduction related basalts: evidence for a three component model. Contributions to Mineralogy and Petrology 98, 72-80.

Elliott, T. (2003). Tracers of the Slab. In: Eiler, J. (ed.) Inside the Subduction Factory. American Geophysical Union, 23-45.

Elliott, T., Plank, T., Zindler, A., White, W. \& Bourdon, B. (1997). Element transport from slab to volcanic front at the Mariana arc. Journal of Geophysical Research: Solid Earth 102, 14991-15019.

Evans, K. A. (2012). The redox budget of subduction zones. Earth-Science Reviews 113, $11-$ 32.

Evans, K. A., Tomkins, A. G., Cliff, J. \& Fiorentini, M. L. (2014). Insights into subduction zone sulfur recycling from isotopic analysis of eclogite-hosted sulfides. Chemical Geology 365, 1-19.Foley, S., Tiepolo, M. \& Vannucci, R. (2002). Growth of early continental crust controlled by melting of amphibolite in subduction zones. Nature 417, 837-840.

Fogel, R. A. \& Rutherford, M. J. (1990). The solubility of carbon dioxide in rhyolitic melts: a quantitative FTIR study. American Mineralogist 75, 1311-1326.

Frezzotti, M. L. \& Ferrando, S. (2015). The chemical behavior of fluids released during deep subduction based on fluid inclusions. American Mineralogist. GeoScienceWorld 100, $352-377$.

Ganguly, J. (1972). Staurolite Stability and Related Parageneses: Theory, Experiments, and Applications. Journal of Petrology 13, 335-365.

Gertisser, R. \& Keller, J. (2003). Trace Element and Sr, Nd, Pb and O Isotope Variations in Medium-K and High-K Volcanic Rocks from Merapi Volcano, Central Java, Indonesia: Evidence for the Involvement of Subducted Sediments in Sunda Arc Magma Genesis. Journal of Petrology. Oxford Academic 44, 457-489.

Goldhaber, M. B. (2003). Sulfur-rich Sediments. In: Holland, H.D., Turekian, K.K (eds.). Treatise on Geochemistry 7, 407. 
Green, T. H. (1995). Significance of $\mathrm{Nb} / \mathrm{Ta}$ as an indicator of geochemical processes in the crust-mantle system. Chemical Geology 120, 347-359.

Green, T. H. \& Adam, J. (2003). Experimentally-determined trace element characteristics of aqueous fluid from partially dehydrated mafic oceanic crust at $3.0 \mathrm{GPa}, 650-700^{\circ} \mathrm{C}$. European Journal of Mineralogy 15, 815-830.

Guidotti, C. V. (1970). The Mineralogy and Petrology of the Transition from the Lower to Upper Sillimanite Zone in the Oquossoc Area, Maine. Journal of Petrology. Oxford Academic 11, 277-336.

Hawkesworth, C. J., Turner, S. P., McDermott, F., Peate, D. W. \& Calsteren, P. van (1997). U-Th Isotopes in Arc Magmas: Implications for Element Transfer from the Subducted Crust. Science. American Association for the Advancement of Science 276, 551-555.

Hermann, J. (2002). Experimental constraints on phase relations in subducted continental crust. Contributions to Mineralogy and Petrology 143, 219-235.

Hermann, J. \& Green, D. H. (2001). Experimental constraints on high pressure melting in subducted crust. Earth and Planetary Science Letters 188, 149-168.

Hermann, J. \& Rubatto, D. (2009). Accessory phase control on the trace element signature of sediment melts in subduction zones. Chemical Geology 265, 512-526.

Hermann, J. \& Spandler, C. J. (2008). Sediment Melts at Sub-arc Depths: an Experimental Study. Journal of Petrology 49, 717-740.

Hoffmann, J. E., Münker, C., Næraa, T., Rosing, M. T., Herwartz, D., Garbe-Schönberg, D. \& Svahnberg, H. (2011). Mechanisms of Archean crust formation inferred from highprecision HFSE systematics in TTGs. Geochimica et Cosmochimica Acta 75, $4157-$ 4178 .

Holloway, J. R., Pan, V. \& Gudmundsson, G. (1992). High-pressure fluid-absent melting experiments in the presence of graphite: oxygen fugacity, ferric/ferrous ratio and dissolved CO2. European Journal of Mineralogy 4, 105-114.

Israel, C., Boyet, M., Doucelance, R., Bonnand, P., Frossard, P., Auclair, D. \& Bouvier, A. (2020). Formation of the Ce-Nd mantle array: Crustal extraction vs. recycling by subduction. Earth and Planetary Science Letters 530, 115941.

Jacob, D. E. (2006). High Sensitivity Analysis of Trace Element-Poor Geological Reference Glasses by Laser Ablation-Inductively Coupled Plasma-Mass Spectrometry (LA-ICPMS). Geostandards and Geoanalytical Research 30, 221-235.

Jégo, S. \& Dasgupta, R. (2013). Fluid-present melting of sulfide-bearing ocean-crust: Experimental constraints on the transport of sulfur from subducting slab to mantle wedge. Geochimica et Cosmochimica Acta 110, 106-134. 
Jégo, S. \& Dasgupta, R. (2014). The Fate of Sulfur During Fluid-Present Melting of

Subducting Basaltic Crust at Variable Oxygen Fugacity. Journal of Petrology 55, 10191050 .

Jochum, K. P., Polat, A., Stoll, B. \& Hofmann, A. W. (2001). Low Nb/Ta in the Archean mantle: implications for the missing Niobium in the silicate Earth. EOS Trans 82, F1214.

Jochum, K. P., Willbold, M., Raczek, I., Stoll, B. \& Herwig, K. (2005). Chemical Characterisation of the USGS Reference Glasses GSA-1G, GSC-1G, GSD-1G, GSE$1 \mathrm{G}, \mathrm{BCR}-2 \mathrm{G}, \mathrm{BHVO}-2 \mathrm{G}$ and BIR-1G Using EPMA, ID-TIMS, ID-ICP-MS and LAICP-MS. Geostandards and Geoanalytical Research 29, 285-302.

Jochum, K.P, Stolz, A.J \& Mcorist, G. (2000). Niobium and tantalum in carbonaceous chondrites: Constraints on the solar system and primitive mantle niobium/tantalum, zirconium/niobium, and niobium/uranium ratio. Meteoritics \& Planetary Science 35, 229-235.

Johnson, M. C. \& Plank, T. (1999). Dehydration and melting experiments constrain the fate of subducted sediments. Geochemistry, Geophysics, Geosystems 1, 1007.

Johnson, T. E., Brown, M., Gardiner, N. J., Kirkland, C. L. \& Smithies, R. H. (2017). Earth's first stable continents did not form by subduction. Nature. Nature Publishing Group 543, 239-242.

Johnson, T. E., Kirkland, C. L., Gardiner, N. J., Brown, M., Smithies, R. H. \& Santosh, M. (2019). Secular change in TTG compositions: Implications for the evolution of Archaean geodynamics. Earth and Planetary Science Letters 505, 65-75.

Jugo, P. (2009). Sulfur content at sulfide saturation in oxidized magmas. Geology 37, 415418.

Jugo, P. J., Luth, R. W. \& Richards, J. P. (2005). Experimental data on the speciation of sulfur as a function of oxygen fugacity in basaltic melts. Geochimica et Cosmochimica Acta 69, 497-503.

Kägi, R., Müntener, O., Ulmer, P. \& Ottolini, L. (2005). Piston-cylinder experiments on $\mathrm{H}_{2} \mathrm{O}$ undersaturated Fe-bearing systems: An experimental setup approaching $f \mathrm{O}_{2}$ conditions of natural calc-alkaline magmas. American Mineralogist 90, 708-717.

Kamber, B. S. \& Collerson, K. D. (2000). Role of 'hidden' deeply subducted slabs in mantle depletion. Chemical Geology 166, 241-254.

Kay, R. W. (1980). Volcanic Arc Magmas: Implications of a Melting-Mixing Model for Element Recycling in the Crust-Upper Mantle System. The Journal of Geology. The University of Chicago Press 88, 497-522. 
Kelley, K. A. \& Cottrell, E. (2009). Water and the Oxidation State of Subduction Zone Magmas. Science 325, 605-607.

Kelley, K. A., Plank, T., Farr, L., Ludden, J. \& Staudigel, H. (2005). Subduction cycling of U, Th, and $\mathrm{Pb}$. Earth and Planetary Science Letters 234, 369-383.

Kepezhinskas, P., Defant, M. J. \& Drummond, M. S. (1996). Progressive enrichment of island arc mantle by melt-peridotite interaction inferred from Kamchatka xenoliths. Geochimica et Cosmochimica Acta 60, 1217-1229.

Kepezhinskas, P. K., Defant, M. J. \& Drummond, M. S. (1995). Na Metasomatism in the Island-Arc Mantle by Slab Melt_-Peridotite Interaction: Evidence from Mantle Xenoliths in the North Kamchatka Arc. Journal of Petrology 36, 1505-1527.

Keppler, H. (1996). Constraints from partitioning experiments on the composition of subduction-zone fluids. Nature 380, 237-240.

Kessel, R., Schmidt, M. W., Ulmer, P. \& Pettke, T. (2005a). Trace element signature of subduction-zone fluids, melts and supercritical liquids at 120-180 km depth. Nature 437, 724-727.

Kessel, R., Ulmer, P., Pettke, T., Schmidt, M. W. \& Thompson, A. B. (2005b). The waterbasalt system at 4 to $6 \mathrm{GPa}$ : Phase relations and second critical end point in a K-free eclogite at 700 to $1400^{\circ} \mathrm{C}$. Earth and Planetary Science Letters 237, 873-892.

Klemme, S., Prowatke, S., Hametner, K. \& Günther, D. (2005). Partitioning of trace elements between rutile and silicate melts: Implications for subduction zones. Geochimica et Cosmochimica Acta 69, 2361-2371.

Klimm, K., Blundy, J. D. \& Green, T. H. (2008). Trace Element Partitioning and Accessory Phase Saturation during $\mathrm{H}_{2} \mathrm{O}$-Saturated Melting of Basalt with Implications for Subduction Zone Chemical Fluxes. Journal of Petrology 49, 523-553.

Kovalenko, N. I. \& Ryzhenko, B. N. (2009). Comparative study of the solubility of zircon and baddeleyite. Geochemistry International 47, 405-413.

Krenn, E., Putz, H., Finger, F. \& Paar, W. H. (2011). Sulfur-rich monazite with high common $\mathrm{Pb}$ in ore-bearing schists from the Schellgaden mining district (Tauern Window, Eastern Alps). Mineralogy and Petrology 102, 51.

Li, H. \& Hermann, J. (2015). Apatite as an indicator of fluid salinity: An experimental study of chlorine and fluorine partitioning in subducted sediments. Geochimica et Cosmochimica Acta 166, 267-297.

Li, J.-L., Gao, J., Klemd, R., John, T. \& Wang, X.-S. (2016). Redox processes in subducting oceanic crust recorded by sulfide-bearing high-pressure rocks and veins (SW Tianshan, China). Contributions to Mineralogy and Petrology 171, 72. 
Li, J.-L., Schwarzenbach, E. M., John, T., Ague, J. J., Huang, F., Gao, J., Klemd, R., Whitehouse, M. J. \& Wang, X.-S. (2020). Uncovering and quantifying the subduction zone sulfur cycle from the slab perspective. Nature Communications. Nature Publishing Group 11, 514.

Li, L., Xiong, X. L. \& Liu, X. C. (2017). Nb/Ta Fractionation by Amphibole in Hydrous Basaltic Systems: Implications for Arc Magma Evolution and Continental Crust Formation. Journal of Petrology 58, 3-28.

Li, Y. \& Audétat, A. (2013) Gold solubility and partitioning between sulfide liquid, monosulfide solid solution and hydrous mantle melts: implications for crust-mantle differentiation and the formation of Au-rich magmas. Geochimica et Cosmochimica Acta 118, 247-262.

Li, Y. \& Audétat, A. (2015). Effects of temperature, silicate melt composition, and oxygen fugacity on the partitioning of V, Mn, Co, Ni, Cu, Zn, As, Mo, Ag, Sn, Sb, W, Au, Pb, and Bi between sulfide phases and silicate melt. Geochimica et Cosmochimica Acta $162,25-45$.

Li, Y., Feng, L., Kiseeva, E. S., Gao, Z., Guo, H., Du, Z., Wang, F. \& Shi, L. (2019). An essential role for sulfur in sulfide-silicate melt partitioning of gold and magmatic gold transport at subduction settings. Earth and Planetary Science Letters 528, 115850.

Li, Y.-H. \& Schoonmaker, J. E. (2014). Chemical Composition and Mineralogy of Marine Sediments. In: Holland, H.D., Turekian, K.K (eds.). Treatise on Geochemistry (Second Edition). Oxford: Elsevier, 1-32.

Linnen, R. L. \& Keppler, H. (2002). Melt composition control of $\mathrm{Zr} / \mathrm{Hf}$ fractionation in magmatic processes. Geochimica et Cosmochimica Acta 66, 3293-3301.

Luhr, J. F. (1990). Experimental Phase Relations of Water- and Sulfur-Saturated Arc Magmas and the 1982 Eruptions of El Chichón Volcano. Journal of Petrology 31, 1071-1114.

Maimaiti, M., Fabbrizio, A., Carroll, M. R., Ertel-Ingrisch, W., Abudureheman, A., Paris, E. \& Dingwell, D. B. (2019). Experimental study of monazite solubility in haplogranitic melts: a new model for peraluminous and peralkaline melts. European Journal of Mineralogy 31, 49-59.

Mallik, A., Nelson, J. \& Dasgupta, R. (2015). Partial melting of fertile peridotite fluxed by hydrous rhyolitic melt at 2-3 GPa: implications for mantle wedge hybridization by sediment melt and generation of ultrapotassic magmas in convergent margins. Contributions to Mineralogy and Petrology 169, 48.

Mann, U. \& Schmidt, M. W. (2015). Melting of pelitic sediments at subarc depths: 1. Flux vs. fluid-absent melting and a parameterization of melt productivity. Chemical Geology 404, 150-167. 
Marschall, H. R. \& Schumacher, J. C. (2012). Arc magmas sourced from mélange diapirs in subduction zones. Nature Geoscience 5, 862-867.

Martel, C., Pichavant, M., Bourdier, J.-L., Traineau, H., Holtz, F. \& Scaillet, B. (1998).

Magma storage conditions and control of eruption regime in silicic volcanoes:

experimental evidence from Mt. Pelée. Earth and Planetary Science Letters 156, 89-99.

Martin, H. (1986). Effect of steeper Archean geothermal gradient on geochemistry of subduction-zone magmas. Geology. GeoScienceWorld 14, 753-756.

Martindale, M., Skora, S., Pickles, J., Elliott, T., Blundy, J. \& Avanzinelli, R. (2013). High pressure phase relations of subducted volcaniclastic sediments from the west pacific and their implications for the geochemistry of Mariana arc magmas. Chemical Geology 342, 94-109.

Massonne, H.-J. \& Szpurka, Z. (1997). Thermodynamic properties of white micas on the basis of high-pressure experiments in the systems $\mathrm{K}_{2} \mathrm{O}-\mathrm{MgO}-\mathrm{Al}_{2} \mathrm{O}_{3}-\mathrm{SiO}_{2}-\mathrm{H}_{2} \mathrm{O}$ and $\mathrm{K}_{2} \mathrm{O}-\mathrm{FeO}-$ $\mathrm{Al}_{2} \mathrm{O}_{3}-\mathrm{SiO}_{2}-\mathrm{H}_{2} \mathrm{O}$. Lithos 41, 229-250.

McCuaig, T. C., Kerrich, R. \& Xie, Q. (1994). Phosphorus and high field strength element anomalies in Archean high-magnesian magmas as possible indicators of source mineralogy and depth. Earth and Planetary Science Letters 124, 221-239.

McDade, P., Wood, B. J., Westrenen, W. V., Brooker, R., Gudmundsson, G., Soulard, H., Najorka, J. \& Blundy, J. (2002). Pressure corrections for a selection of piston-cylinder cell assemblies. Mineralogical Magazine. Cambridge University Press 66, 1021-1028.

McDermott, F., Defant, M. J., Hawkesworth, C. J., Maury, R. C. \& Joron, J. L. (1993). Isotope and trace element evidence for three component mixing in the genesis of the North Luzon arc lavas (Philippines). Contributions to Mineralogy and Petrology 113, $9-23$.

McDonough, W. F. \& Sun, S.-s. (1995). The composition of the Earth. Chemical Geology 120, 223-253.

Métrich, N., Schiano, P., Clocchiatti, R. \& Maury, R. C. (1999). Transfer of sulfur in subduction settings: an example from Batan Island (Luzon volcanic arc, Philippines). Earth and Planetary Science Letters 167, 1-14.

Miller, D. M., Goldstein, S. L. \& Langmuir, C. H. (1994). Cerium/lead and lead isotope ratios in arc magmas and the enrichment of lead in the continents. Nature 368, 514-520.

Montel, J.-M. (1993). A model for monazite/melt equilibrium and application to the generation of granitic magmas. Chemical Geology 110, 127-146.

Morris, J. D., Leeman, W. P. \& Tera, F. (1990). The subducted component in island arc lavas: constraints from Be isotopes and B-Be systematics. Nature 344, 31-36. 
Moyen, J.-F. (2011). The composite Archaean grey gneisses: Petrological significance, and evidence for a non-unique tectonic setting for Archaean crustal growth. Lithos 123, 21-36.

Münker, C., Pfänder, J. A., Weyer, S., Büchl, A., Kleine, T. \& Mezger, K. (2003). Evolution of Planetary Cores and the Earth-Moon System from Nb/Ta Systematics. Science. American Association for the Advancement of Science 301, 84-87.

Münker, C., Wörner, G., Yogodzinski, G. \& Churikova, T. (2004). Behaviour of high field strength elements in subduction zones: constraints from Kamchatka-Aleutian arc lavas. Earth and Planetary Science Letters 224, 275-293.

Næraa, T., Scherstén, A., Rosing, M. T., Kemp, A. I. S., Hoffmann, J. E., Kokfelt, T. F. \& Whitehouse, M. J. (2012). Hafnium isotope evidence for a transition in the dynamics of continental growt.h 3.2 Gyr ago. Nature. Nature Publishing Group 485, 627-630.

Nash, W. P. \& Crecraft, H. R. (1985). Partition coefficients for trace elements in silicic magmas. Geochimica et Cosmochimica Acta 49, 2309-2322.

Nebel, O., Vroon, P. Z., van Westrenen, W., Iizuka, T. \& Davies, G. R. (2011). The effect of sediment recycling in subduction zones on the Hf isotope character of new arc crust, Banda arc, Indonesia. Earth and Planetary Science Letters 303, 240-250.

Nesbitt, B. E. (1986a). Oxide-sulfide-silicate equilibria associated with metamorphosed ore deposits; Part I, Theoretical considerations. Economic Geology. GeoScienceWorld 81, 831-840.

Nesbitt, B. E. (1986b). Oxide-sulfide-silicate equilibria associated with metamorphosed ore deposits; Part II, Pelitic and felsic volcanic terrains. Economic Geology. GeoScienceWorld 81, 841-856.

Nichols, G. T., Wyllie, P. J. \& Stern, C. R. (1994). Subduction zone melting of pelagic sediments constrained by melting experiments. Nature 371, 785-788.

Parat, F., Holtz, F. \& Feig, S. (2008). Pre-eruptive Conditions of the Huerto Andesite (Fish Canyon System, San Juan Volcanic Field, Colorado): Influence of Volatiles (C-O-HS) on Phase Equilibria and Mineral Composition. Journal of Petrology 49, 911-935.

Pearce, J. A., Stern, R. J., Bloomer, S. H. \& Fryer, P. (2005). Geochemical mapping of the Mariana arc-basin system: Implications for the nature and distribution of subduction components. Geochemistry, Geophysics, Geosystems 6.

Pichavant, M. (1987). The Macusani glasses, SE Peru: evidence of chemical fractionation in peraluminous magmas. Magmatic Process: Physicochemical Principles. Geochem. Soc. Spec. Publ. 1, 359-373. 
Pichavant, M., Villaros, A., Deveaud, S., Scaillet, B. \& Lahlafi, M. (2016). The Influence of Redox State On Mica Crystallization in Leucogranitic and Pegmatitic Liquids. The Canadian Mineralogist 54, 559-581.

Plank, T. (2005). Constraints from Thorium/Lanthanum on Sediment Recycling at Subduction Zones and the Evolution of the Continents. Journal of Petrology 46, 921-944.

Plank, T. (2014). The Chemical Composition of Subducting Sediments. In: Holland, H.D., Turekian, K.K (eds.). Treatise on Geochemistry (Second Edition). Oxford: Elsevier, 607-629.

Plank, T. \& Langmuir, C. H. (1992). Effects of the melting regime on the composition of the oceanic crust. Journal of Geophysical Research: Solid Earth 97, 19749-19770.

Plank, T. \& Langmuir, C. H. (1993). Tracing trace elements from sediment input to volcanic output at subduction zones. Nature 362, 739-743.

Plank, T. \& Langmuir, C. H. (1998). The chemical composition of subducting sediment and its consequences for the crust and mantle. Chemical Geology 145, 325-394.

Poli, S. \& Schmidt, M. W. (2002). Petrology of Subducted Slabs. Annual Review of Earth and Planetary Sciences 30, 207-235.

Pons, M.-L., Debret, B., Bouilhol, P., Delacour, A. \& Williams, H. (2016). Zinc isotope evidence for sulfate-rich fluid transfer across subduction zones. Nature Communications $7,1-8$.

Popp, R. K., Gilbert, M. C. \& Craig, J. R. (1977). Stability of Fe-Mg amphiboles with respect to oxygen fugacity. American Mineralogist. GeoScienceWorld 62, 1-12.

Powell, R. \& Holland, T. (1990). Calculated mineral equilibria in the pelite system, KFMASH $\left(\mathrm{K}_{2} \mathrm{O}-\mathrm{FeO}-\mathrm{MgO}-\mathrm{Al}_{2} \mathrm{O}_{3}-\mathrm{SiO}_{2}-\mathrm{H}_{2} \mathrm{O}\right)$. American Mineralogist 75, 367-380.

Prouteau, G. \& Scaillet, B. (2013). Experimental Constraints on Sulphur Behaviour in Subduction Zones: Implications for TTG and Adakite Production and the Global Sulphur Cycle since the Archean. Journal of Petrology 54, 183-213.

Prouteau, G., Scaillet, B., Pichavant, M. \& Maury, R. (2001). Evidence for mantle metasomatism by hydrous silicic melts derived from subducted oceanic crust. Nature 410, 197-200.

Prouteau, G., Scaillet, B., Pichavant, M. \& Maury, R. C. (1999). Fluid-present melting of ocean crust in subduction zones. Geology 27, 1111-1114.

Regelous, M., Collerson, K. D., Ewart, A. \& Wendt, J. I. (1997). Trace element transport rates in subduction zones: evidence from $\mathrm{Th}, \mathrm{Sr}$ and $\mathrm{Pb}$ isotope data for Tonga-Kermadec arc lavas. Earth and Planetary Science Letters 150, 291-302. 
Reimink, J. R., Chacko, T., Stern, R. A. \& Heaman, L. M. (2016). The birth of a cratonic nucleus: Lithogeochemical evolution of the 4.02-2.94 Ga Acasta Gneiss Complex. Precambrian Research 281, 453-472.

Rey, P. F. \& Coltice, N. (2008). Neoarchean lithospheric strengthening and the coupling of Earth's geochemical reservoirs. Geology 36, 635-638.

Richardson, S. W. (1968). Staurolite Stability in a Part of the System Fe-Al-Si-O-H. Journal of Petrology 9, 467-488.

Rielli, A., Tomkins, A. G., Nebel, O., Brugger, J., Etschmann, B., Zhong, R., Yaxley, G.M. \& Paterson, D. (2017). Evidence of sub-arc mantle oxidation by sulphur and carbon. Geochemical Perspectives Letters 3, 124-132.

Roberts, N. M. W. \& Santosh, M. (2018). Capturing the Mesoarchean Emergence of Continental Crust in the Coorg Block, Southern India. Geophysical Research Letters 45, 7444-7453.

Rubatto, D. (2002). Zircon trace element geochemistry: partitioning with garnet and the link between $\mathrm{U}-\mathrm{Pb}$ ages and metamorphism. Chemical Geology 184, 123-138.

Rubatto, D. \& Hermann, J. (2007). Experimental zircon/melt and zircon/garnet trace element partitioning and implications for the geochronology of crustal rocks. Chemical Geology 241, 38-61.

Rudnick, R. L., Barth, M., Horn, I. \& McDonough, W. F. (2000). Rutile-Bearing Refractory Eclogites: Missing Link Between Continents and Depleted Mantle. Science. American Association for the Advancement of Science 287, 278-281.

Ryan, J. G. \& Chauvel, C. (2014). The Subduction-Zone Filter and the Impact of Recycled Materials on the Evolution of the Mantle. In: Holland, H.D., Turekian, K.K (eds.). Treatise on Geochemistry (Second Edition). Oxford: Elsevier, 479-508.

Ryerson, F. J. \& Watson, E. B. (1987). Rutile saturation in magmas: implications for TiNbTa depletion in island-arc basalts. Earth and Planetary Science Letters 86, 225-239.

Salters, V. J. M. \& Stracke, A. (2004). Composition of the depleted mantle. Geochemistry, Geophysics, Geosystems 5, Q05B07.

Scaillet, B., Clemente, B., Evans, B. W. \& Pichavant, M. (1998). Redox control of sulfur degassing in silicic magmas. Journal of Geophysical Research: Solid Earth 103, 23937-23949.

Scaillet, B. \& Evans, B. W. (1999). The 15 June 1991 Eruption of Mount Pinatubo. I. Phase Equilibria and Pre-eruption $\mathrm{P}-\mathrm{T}-\mathrm{fO}_{2}-f \mathrm{H}_{2} \mathrm{O}$ Conditions of the Dacite Magma. Journal of Petrology 40, 381-411. 
Scaillet, B. \& Macdonald, R. (2006). Experimental and Thermodynamic Constraints on the Sulphur Yield of Peralkaline and Metaluminous Silicic Flood Eruptions. Journal of Petrology 47, 1413-1437.

Scaillet, B. \& Pichavant, M. (2003). Experimental constraints on volatile abundances in arc magmas and their implications for degassing processes. Geological Society, London, Special Publications. Geological Society of London 213, 23-52.

Scaillet, B., Pichavant, M. \& Roux, J. (1995). Experimental Crystallization of Leucogranite Magmas. Journal of Petrology 36, 663-705.

Schiano, P., Clocchiatti, R., Shimizu, N., Maury, R. C., Jochum, K. P. \& Hofmann, A. W. (1995). Hydrous, silica-rich melts in the sub-arc mantle and their relationship with erupted arc lavas. Nature 377, 595-600.

Schmidt, M. W. (1996). Experimental Constraints on Recycling of Potassium from Subducted Oceanic Crust. Science 272, 1927-1930.

Schmidt, M. W., Dardon, A., Chazot, G. \& Vannucci, R. (2004a). The dependence of Nb and Ta rutile-melt partitioning on melt composition and $\mathrm{Nb} / \mathrm{Ta}$ fractionation during subduction processes. Earth and Planetary Science Letters 226, 415-432.

Schmidt, M. W. \& Jagoutz, O. (2017). The global systematics of primitive arc melts. Geochemistry, Geophysics, Geosystems 18, 2817-2854.

Schmidt, M. W. \& Poli, S. (2014). Devolatilization During Subduction. In: Holland, H.D., Turekian, K.K (eds.).. Treatise on Geochemistry (Second Edition). Oxford: Elsevier, 669-701.

Schmidt, M. W. \& Ulmer, P. (2004). A rocking multianvil: elimination of chemical segregation in fluid-saturated high-pressure experiments. Geochimica et Cosmochimica Acta 68, 1889-1899.

Schmidt, M. W., Vielzeuf, D. \& Auzanneau, E. (2004b). Melting and dissolution of subducting crust at high pressures: the key role of white mica. Earth and Planetary Science Letters 228, 65-84.

Smye, A.J., Greenwood, L.V. \& Holland, J.B. (2010). Garnet-chloritoid-kyanite assemblages: eclogite facies indicators of subduction constraints in orogenic belts. Journal of Metamorphic Geology 28, 753-768.

Simon, G. \& Chopin, C. (2001). Enstatite-sapphirine crack-related assemblages in ultrahighpressure pyrope megablasts, Dora-Maira massif, western Alps. Contributions to Mineralogy and Petrology 140, 422-440. 
Sisson, T. W., Ratajeski, K., Hankins, W. B. \& Glazner, A. F. (2005). Voluminous granitic magmas from common basaltic sources. Contributions to Mineralogy and Petrology 148, 635-661.

Skora, S. \& Blundy, J. (2010). High-pressure Hydrous Phase Relations of Radiolarian Clay and Implications for the Involvement of Subducted Sediment in Arc Magmatism. Journal of Petrology 51, 2211-2243.

Skora, S. \& Blundy, J. (2012). Monazite solubility in hydrous silicic melts at high pressure conditions relevant to subduction zone metamorphism. Earth and Planetary Science Letters 321-322, 104-114.

Skora, S., Blundy, J. D., Brooker, R. A., Green, E. C. R., de Hoog, J. C. M. \& Connolly, J. A. D. (2015). Hydrous Phase Relations and Trace Element Partitioning Behaviour in Calcareous Sediments at Subduction-Zone Conditions. Journal of Petrology 56, 953980 .

Skora, S., Freymuth, H., Blundy, J., Elliott, T. \& Guillong, M. (2017). An experimental study of the behaviour of cerium/molybdenum ratios during subduction: Implications for tracing the slab component in the Lesser Antilles and Mariana Arc. Geochimica et Cosmochimica Acta 212, 133-155.

Smit, M. A. , Scherstén, A., Næraa, T., Emo, R. B., Scherer, E.E., Sprung, P., Bleeker, W., Mezger, K., Maltese, A., Cai, Y., Rasbury, E.T. \& Whitehouse, M.J. (2019). Formation of Archean continental crust constrained by boron isotopes. Geochemical Perspectives Letters 12, 23-26.

Smithies, R.H., Champion, D.C. \& Cassidy, K.F., 2003. Formation of Earth's early Archaean continental crust. Precambrian Research 127, 89-101.

Spandler, C., Pettke, T. \& Hermann, J. (2014). Experimental study of trace element release during ultrahigh-pressure serpentinite dehydration. Earth and Planetary Science Letters 391, 296-306.

Stepanov, A. S. \& Hermann, J. (2013). Fractionation of Nb and Ta by biotite and phengite: Implications for the "missing Nb paradox." Geology 41, 303-306.

Stepanov, A. S., Hermann, J., Rubatto, D. \& Rapp, R. P. (2012). Experimental study of monazite/melt partitioning with implications for the REE, Th and U geochemistry of crustal rocks. Chemical Geology 300-301, 200-220.

Stolper, E. M., Fine, G. J., Johnson, T. \& Newman, S. (1987). The solubility of carbon dioxide in albitic melts. American Mineralogist 72, 1071-1085.

Syracuse, E. M., van Keken, P. E. \& Abers, G. A. (2010). The global range of subduction zone thermal models. Physics of the Earth and Planetary Interiors 183, 73-90. 
Tang, M., Lee, C.-T. A., Chen, K., Erdman, M., Costin, G. \& Jiang, H. (2019). Nb/Ta systematics in arc magma differentiation and the role of arclogites in continent formation. Nature Communications. Nature Publishing Group 10, 1-8.

Tao, R., Zhang, L. \& Zhang, L. (2020). Redox evolution of western Tianshan subduction zone and its effect on deep carbon cycle. Geoscience Frontiers 11, 915-924.

Thomsen, T. B. \& Schmidt, M. W. (2008). The Biotite to Phengite Reaction and Micadominated Melting in Fluid + Carbonate-saturated Pelites at High Pressures. Journal of Petrology 49, 1889-1914.

Tomkins, A. G. \& Evans, K. A. (2015). Separate zones of sulfate and sulfide release from subducted mafic oceanic crust. Earth and Planetary Science Letters 428, 73-83.

Tracy, R. J. \& Robinson, P. (1988). Silicate-sulfide-oxide-fluid reactions in granulite-grade pelitic rocks, central Massachusetts. American Journal of Science 288, 45-74.

Trail, D., Boehnke, P., Savage, P. S., Liu, M.-C., Miller, M. L. \& Bindeman, I. (2018). Origin and significance of $\mathrm{Si}$ and $\mathrm{O}$ isotope heterogeneities in Phanerozoic, Archean, and Hadean zircon. Proceedings of the National Academy of Sciences. National Academy of Sciences 115, 10287-10292.

Truckenbrodt, J., Ziegenbein, D. \& Johannes, W. (1997). Redox conditions in piston-cylinder apparatus: The different behavior of boron nitride and unfired pyrophyllite assemblies. American Mineralogist 82, 337-344.

Turner, S., Caulfield, J., Turner, M., van Keken, P., Maury, R., Sandiford, M. \& Prouteau, G. (2012). Recent contribution of sediments and fluids to the mantle's volatile budget. Nature Geoscience 5, 50-54.

Turner, S., Hawkesworth, C., Rogers, N., Bartlett, J., Worthington, T., Hergt, J., Pearce, J. \& Smith, I. (1997). 238U/230Th disequilibria, magma petrogenesis, and flux rates beneath the depleted Tonga-Kermadec island arc. Geochimica et Cosmochimica Acta 61, 48554884.

Ulmer, P. \& Trommsdorff, V. (1995). Serpentine Stability to Mantle Depths and SubductionRelated Magmatism. Science 268, 858-861.

Valley, J. W., Lackey, J.S., Cavosie, A.J., Clechenko, C. C., Spicuzza, C. C., Basei, M. A. S., Bindeman, I. N., Ferreira, V. P., Sial, A. N., King, E. M., Peck, W.H., Sinha, A. K. \& Wei, C. S. (2005). 4.4 billion years of crustal maturation: oxygen isotope ratios of magmatic zircon. Contributions to Mineralogy and Petrology 150, 561-580.

van de Flierdt, T., Goldstein, S. L., Hemming, S. R., Roy, M., Frank, M. \& Halliday, A. N. (2007). Global neodymium-hafnium isotope systematics - revisited. Earth and Planetary Science Letters 259, 432-441. 
van Keken, P. E., Hacker, B. R., Syracuse, E. M. \& Abers, G. A. (2011). Subduction factory: 4. Depth-dependent flux of $\mathrm{H} 2 \mathrm{O}$ from subducting slabs worldwide. Journal of Geophysical Research: Solid Earth 116, B01401.

van Westrenen, W., Wood, B. J. \& Blundy, J. D. (2001). A predictive thermodynamic model of garnet-melt trace element partitioning. Contributions to Mineralogy and Petrology 142, 219-234.

Vannucci, R., Tiepolo, M., Defant, M. J. \& Kepezhinskas, P. (2007). The metasomatic record in the shallow peridotite mantle beneath Grenada (Lesser Antilles arc). Lithos 99, 2544 .

Wade, J. \& Wood, B. J. (2001). The Earth's 'missing' niobium may be in the core. Nature. Nature Publishing Group 409, 75-78.

Wallace, P. J. \& Edmonds, M. (2011). The Sulfur Budget in Magmas: Evidence from Melt Inclusions, Submarine Glasses, and Volcanic Gas Emissions. Reviews in Mineralogy and Geochemistry 73, 215-246.

Walters, J. B., Cruz-Uribe, A. M. \& Marschall, H. R. (2019). Isotopic Compositions of Sulfides in Exhumed High-Pressure Terranes: Implications for Sulfur Cycling in Subduction Zones. Geochemistry, Geophysics, Geosystems 2019GC008374.

Walters, J. B., Cruz-Uribe, A. M. \& Marschall, H. R. (2020). Sulfur loss from subducted altered oceanic crust and implications for mantle oxidation. Geochemical Perspectives Letters 36-41.

Webster, J. D., Vetere, F., Botcharnikov, R. E., Goldoff, B., McBirney, A. \& Doherty, A. L. (2015). Experimental and modeled chlorine solubilities in aluminosilicate melts at 1 to 7000 bars and 700 to $1250{ }^{\circ} \mathrm{C}$ : Applications to magmas of Augustine Volcano, Alaska. American Mineralogist 100, 522-535.

Wei, C. \& Powell, R. (2003). Phase relations in high-pressure metapelites in the system KFMASH $\left(\mathrm{K}_{2} \mathrm{O}-\mathrm{FeO}-\mathrm{MgO}-\mathrm{Al}_{2} \mathrm{O}_{3}-\mathrm{SiO}_{2}-\mathrm{H}_{2} \mathrm{O}\right)$ with application to natural rocks. Contributions to Mineralogy and Petrology 145, 301-315.

White, W. M. \& Patchett, J. (1984). Hf-Nd-Sr isotopes and incompatible element abundances in island arcs: implications for magma origins and crust-mantle evolution. Earth and Planetary Science Letters 67, 167-185.

Woodhead, J. D., Hergt, J. M., Davidson, J. P. \& Eggins, S. M. (2001). Hafnium isotope evidence for 'conservative' element mobility during subduction zone processes. Earth and Planetary Science Letters 192, 331-346.

Xiong, X., Keppler, H., Audétat, A., Ni, H., Sun, W. \& Li, Y. (2011). Partitioning of Nb and Ta between rutile and felsic melt and the fractionation of $\mathrm{Nb} / \mathrm{Ta}$ during partial melting of hydrous metabasalt. Geochimica et Cosmochimica Acta 75, 1673-1692. 
Yardley, B. W. D. (1977). Relationships between the chemical and modal compositions of metapelites from Connemara, Ireland. Lithos 10, 235-242.

Zajacz, Z. (2015). The effect of melt composition on the partitioning of oxidized sulfur between silicate melts and magmatic volatiles. Geochimica et Cosmochimica Acta 158, 223-244.

Zhang, Y. (1999). $\mathrm{H}_{2} \mathrm{O}$ in rhyolitic glasses and melts: measurement, speciation, solubility, and diffusion. Reviews of Geophysics 37, 493-516.

Zhang, Z.-M., Shen, K., Sun, W.-D., Liu, Y.-S., Liou, J. G., Shi, C. \& Wang, J.-L. (2008). Fluids in deeply subducted continental crust: Petrology, mineral chemistry and fluid inclusion of UHP metamorphic veins from the Sulu orogen, eastern China. Geochimica et Cosmochimica Acta 72, 3200-3228.

\section{FIGURE CAPTIONS}

Fig. 1: Trace element compositions of B12a (starting composition of this study) and GLOSSII (Plank, 2014) normalized to PM (Primitive Mantle; McDonough \& Sun, 1995). Blue area corresponds to IAB $(\mathrm{MgO}>6 \mathrm{wt}$. \%) containing unambiguously a sedimentary component in their source, according to the Elliott (2003) criteria $\left(\mathrm{Ba} / \mathrm{Th}<150\right.$ and $\left.\mathrm{La} / \mathrm{Sm}_{\mathrm{PM}}>1\right)(\mathrm{n}=408$ samples, GeoRoc compilation; Supplementary Data 5).

Fig. 2: Representative back-scattered electron (BSE) images of experimental run products (3 GPa, 8.5 wt. \% $\mathrm{H}_{2} \mathrm{O}$ ). Phases abbreviations: Rt, rutile; Zrn, zircon; St, staurolite; Qz, quartz; Grt, garnet; Ky, kyanite; Po, pyrrhotite ; Opx, orthopyroxene; Bt, biotite.

Fig. 3: Cumulative modes (calculated from mass balance on the major oxides, Table 2) for experimental charges, plotted against sulphur addition $\left(\mathrm{S}_{\text {in }}\right)$.

Fig. 4: T-wt. $\% \mathrm{~S}_{\text {in }}$ stability fields of different parageneses of the main minerals in subducted Ca-poor pelite. The approximate stability limits of key phases are indicated; the curves are labelled with mineral lying inside their respective stability fields. Abbreviations as in Fig. $2+$ $\mathrm{Ph}=$ phengite and $\mathrm{Gl}=$ glass. 
Fig. 5: (a) Garnet compositions plotted in molecular proportions of grossular (Grs), almandine (Alm), pyrope (Prp) and spessartine (Sps); (b,c) variations of $\mathrm{X}_{\mathrm{Mg}}$ and $\mathrm{Ca}$ (in cations per formula unit (pfu)) in garnet as a function of temperature. Data from previous studies are represented by grey symbols.

Fig. 6: Variations of Si and Al (in cations pfu) in phengite (a) and biotite (b), after Thomsen \& Schmidt (2008); variations of $\mathrm{X}_{\mathrm{Mg}}$ in phengite (c) and biotite (d) as a function of temperature. Data from previous studies are represented by grey symbols.

Fig. 7: Experimental glass compositions: (a) A/CNK as a function of NK/A; (b, c, d, e, f) variations of melt composition with temperature; (g) anorthite-albite-orthoclase normative triangle; To, tonalite; Tdh, trondhjemite; Gd, granodiorite.

Fig. 8: Sulphur contents (ppm) of experimental glasses as a function of temperature for B12a $\pm \mathrm{S}(\mathrm{a})$ and $\mathrm{B} 12 \mathrm{a}+\mathrm{H}_{2} \mathrm{O} \pm \mathrm{H}_{2} \mathrm{SO} 4$ (b). Vertical bars are 1 standard deviation (when not shown error bars are smaller than the symbol size). Grey symbols show the sulphur content of experimental silicic glasses saturated in sulphide and/or sulphate at $2.3-3 \mathrm{GPa}, 700$ to $1100^{\circ} \mathrm{C}$ and $f \mathrm{O}_{2}=\mathrm{FMQ}-4$ to FMQ+3.5 (Prouteau \& Scaillet, 2013; Jégo \& Dasgupta, 2013, 2014; Canil \& Fellows, 2017; D’Souza \& Canil, 2018).

B12a: Ca-poor pelite with 1-4 wt. \% $\mathrm{S}_{\text {in }}$; TSC: carbonate-rich sediment with 2 wt. \% $\mathrm{S}_{\text {in }}$; GM: Ca-rich synthetic pelite with $0.3-1$ wt. $\% \mathrm{~S}_{\text {in }}$; CM3: Ca-rich pelite with 2 wt. \% $\mathrm{S}_{\text {in }}$; PM: Ferich pelite with 1.9 wt. $\% \mathrm{~S}_{\text {in }}$.

Fig. 9: (a) Trace element compositions of experimental glasses normalized to PM (McDonough \& Sun, 1995). Starting composition is shown as thick black line. Blue area corresponds to IAB with "sediment flavor" (see Fig. 1 for details); (b, c, d, e, f, g) variation of concentration of trace elements (ppm) as a function of temperature. 
Fig. 10: Garnet-melt (a), orthopyroxene-melt (b), biotite-melt (c) and phengite-melt (d) partition coefficients for the trace elements studied. Garnet-melt partition coefficients are compared to the coefficients of Skora \& Blundy (2010) (grey area in (a)).

Fig. 11: Melt productivity at $3 \mathrm{GPa}$ calculated from mass balance (Table 2) as a function of temperature.

Fig. 12: Element fractionation in hydrous melts as a function of temperature. $(\mathrm{Ba} / \mathrm{Th})_{\mathrm{N}}=$ $(\mathrm{Ba} / \mathrm{Th})_{\text {melt }} /(\mathrm{Ba} / \mathrm{Th})_{\text {starting material }}$ etc.

$\mathrm{Zr} / \mathrm{Zr} *=\mathrm{Zr} / 10^{((\operatorname{logNd}+\operatorname{logSm}) / 2)}(\mathrm{McCuaig}$ et al., 1994).

Fig. 13: (a) $(\mathrm{La} / \mathrm{Sm})_{\mathrm{PM}}(\mathrm{McD}$ onough \& Sun, 1995) versus $\mathrm{Ba} / \mathrm{Th}$ and (b) Th versus U/Th for mafic $(\mathrm{MgO}>6$ wt. \%) arc lavas worldwilde, including the Lesser Antilles (compilation from GeoRoc: http://georoc.mpch-mainz.gwdg.de; see Supplementary Data 5 for references).

Superimposed are the chemical compositions of the experimental glasses of this study, as well as the experiments of Skora et al. $(2015,2017)$. 


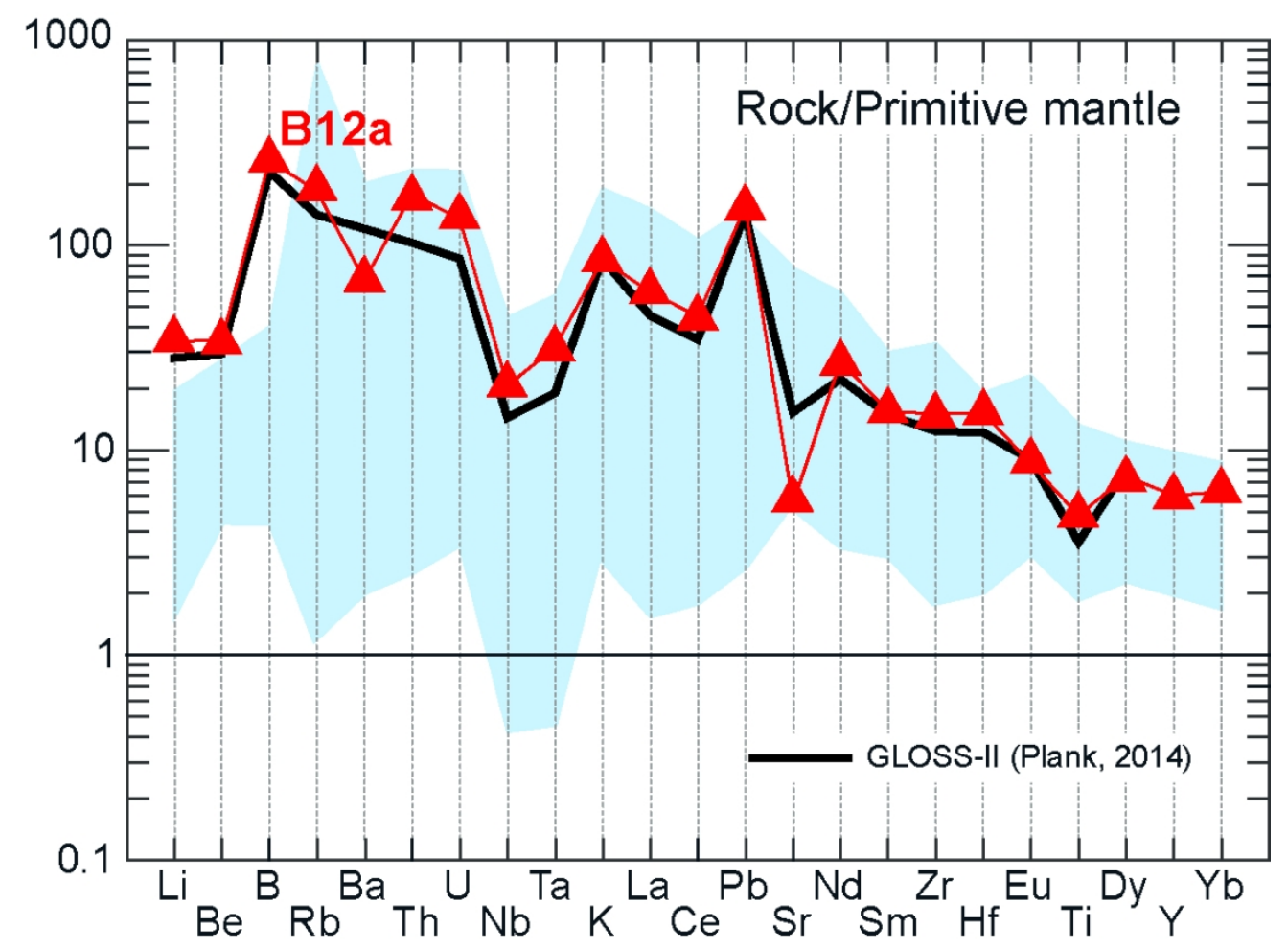

Fig. 1: Trace element compositions of B12a (starting composition of this study) and GLOSS-II (Plank, 2014) normalized to PM (Primitive Mantle; McDonough \& Sun, 1995). Blue area corresponds to IAB (MgO > 6 wt. \%) containing unambiguously a sedimentary component in their source, according to the Elliott (2003) criteria ( $\mathrm{Ba} / \mathrm{Th}<150$ and La/SmPM $>1)$ ( $\mathrm{n}=408$ samples, GeoRoc compilation; Supplementary Data 5). 

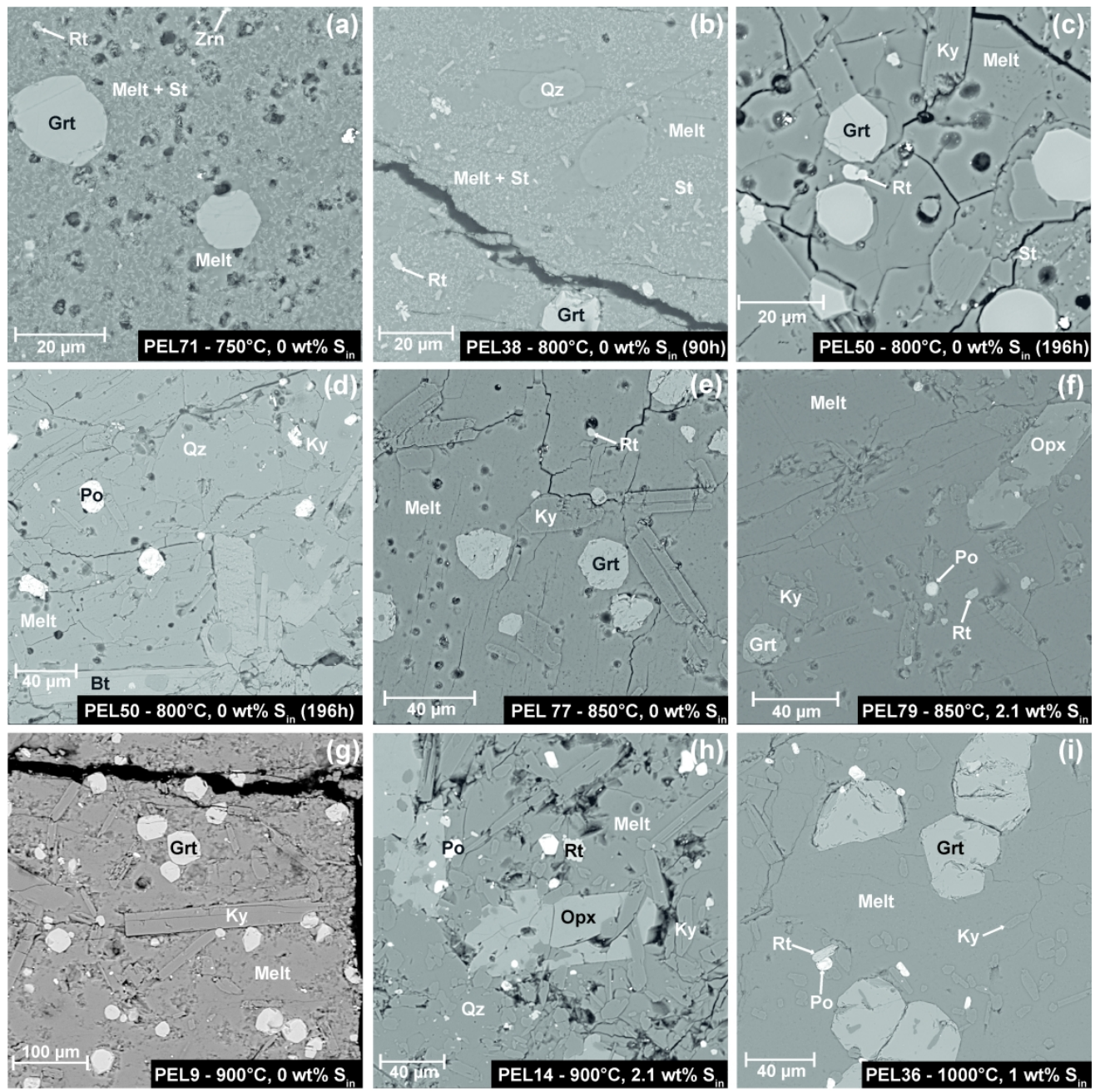

Fig. 2: Representative back-scattered electron (BSE) images of experimental run products ( $3 \mathrm{GPa}, 8.5 \mathrm{wt}$. \% $\mathrm{H}_{2} \mathrm{O}$ ). Phases abbreviations: Rt, rutile; Zrn, zircon; St, staurolite; Qz, quartz; Grt, garnet; Ky, kyanite; Po, pyrrhotite ; Opx, orthopyroxene; Bt, biotite. 

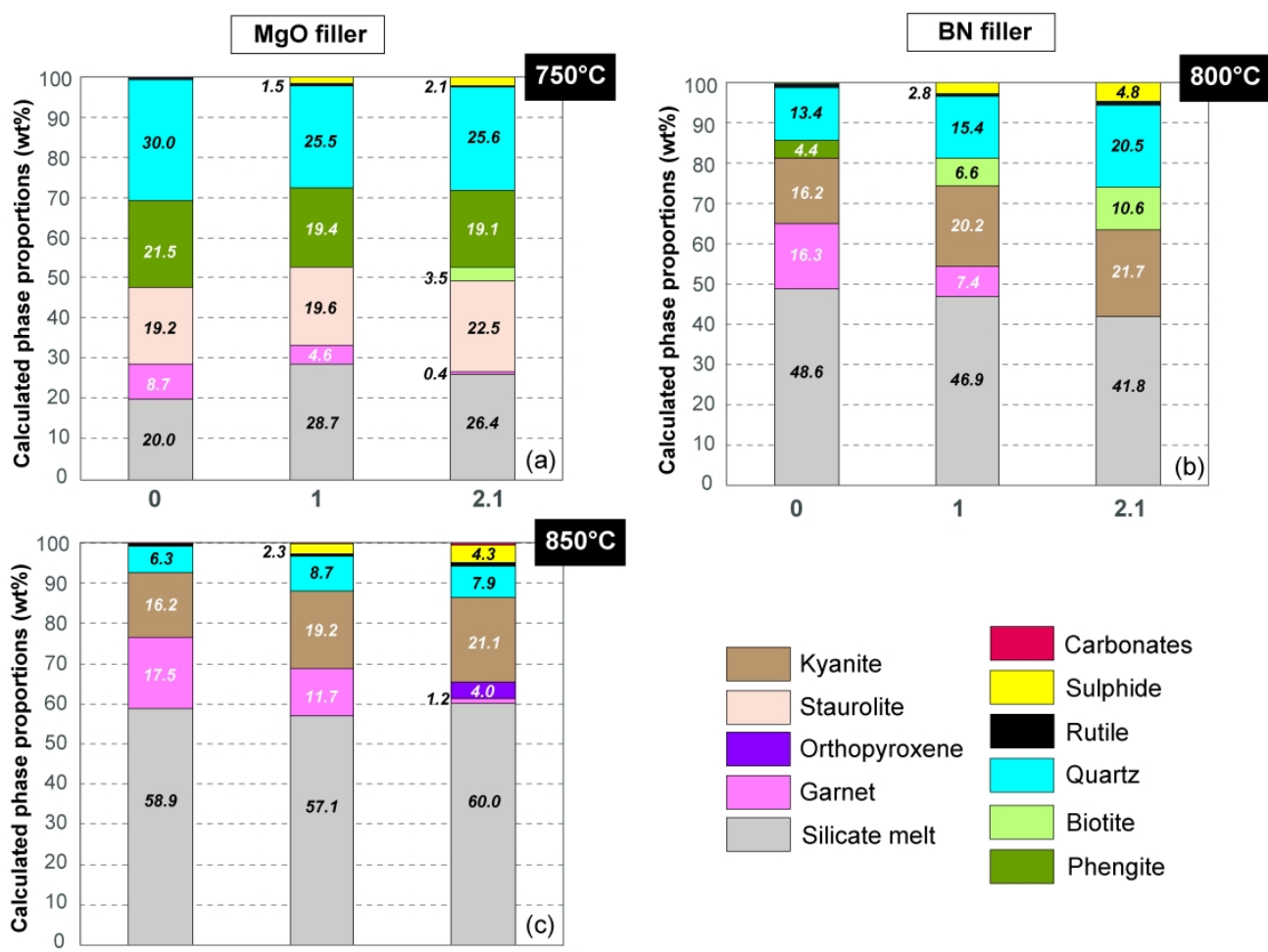

$850^{\circ} \mathrm{C}$
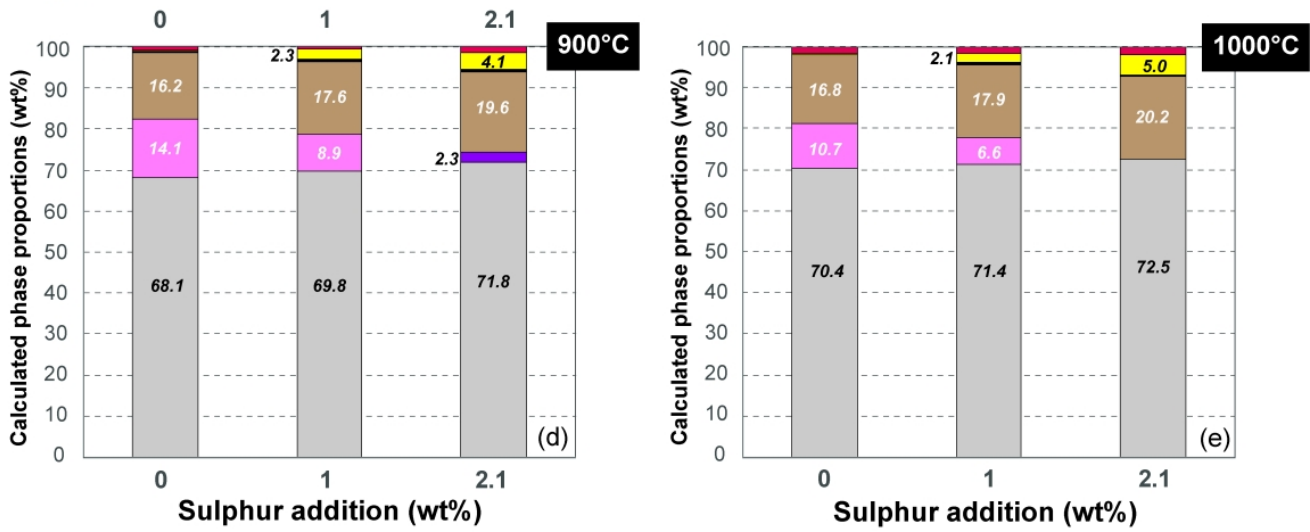

Fig. 3: Cumulative modes (calculated from mass balance on the major oxides, Table 2) for experimental charges, plotted against sulphur addition $\left(S_{i n}\right)$. 


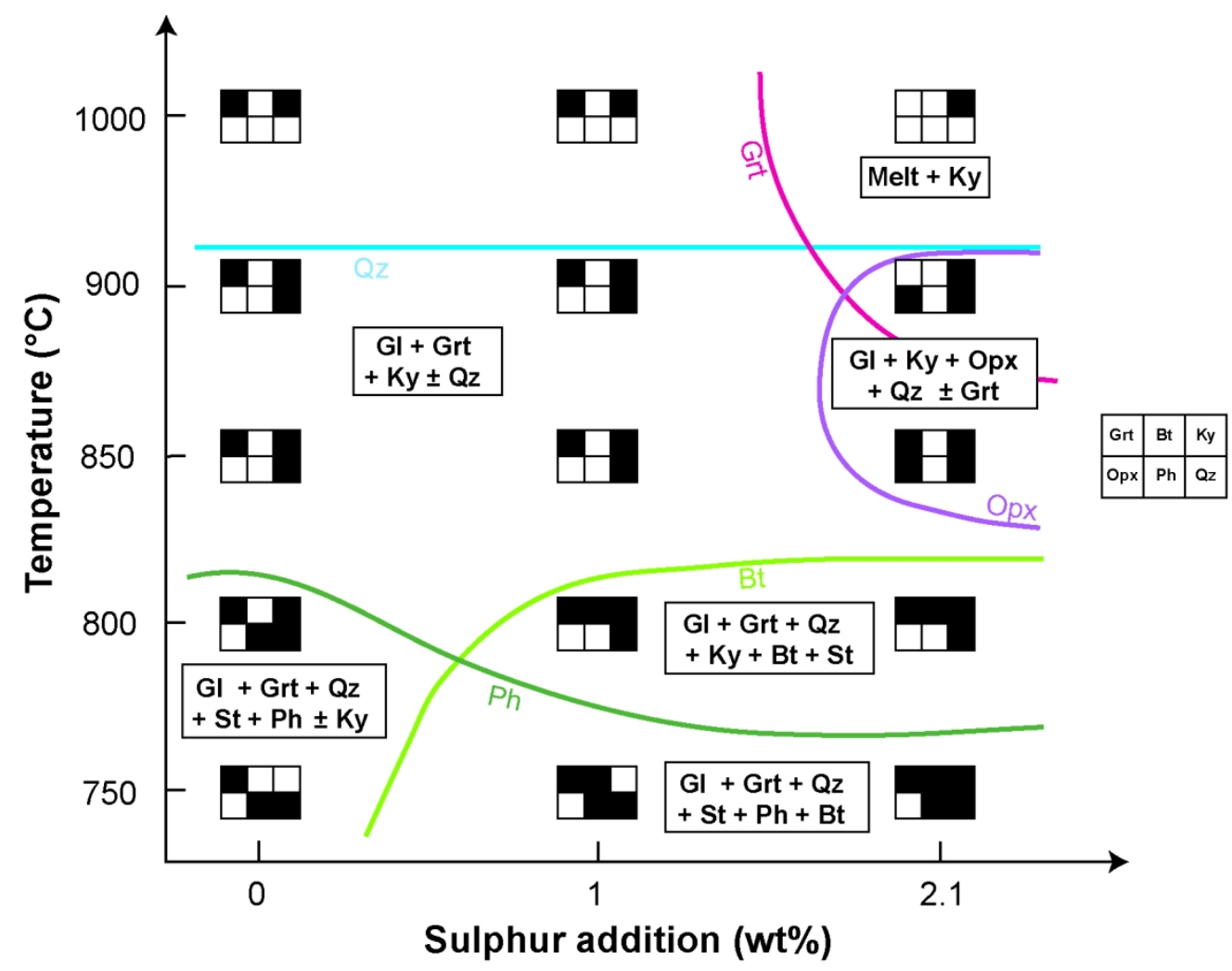

Fig. 4: T-wt. \% $S_{\text {in }}$ stability fields of different parageneses of the main minerals in subducted Ca-poor pelite. The approximate stability limits of key phases are indicated; the curves are labelled with mineral lying inside their respective stability fields. Abbreviations as in Fig. $2+\mathrm{Ph}=$ phengite and $\mathrm{Gl}=$ glass. 

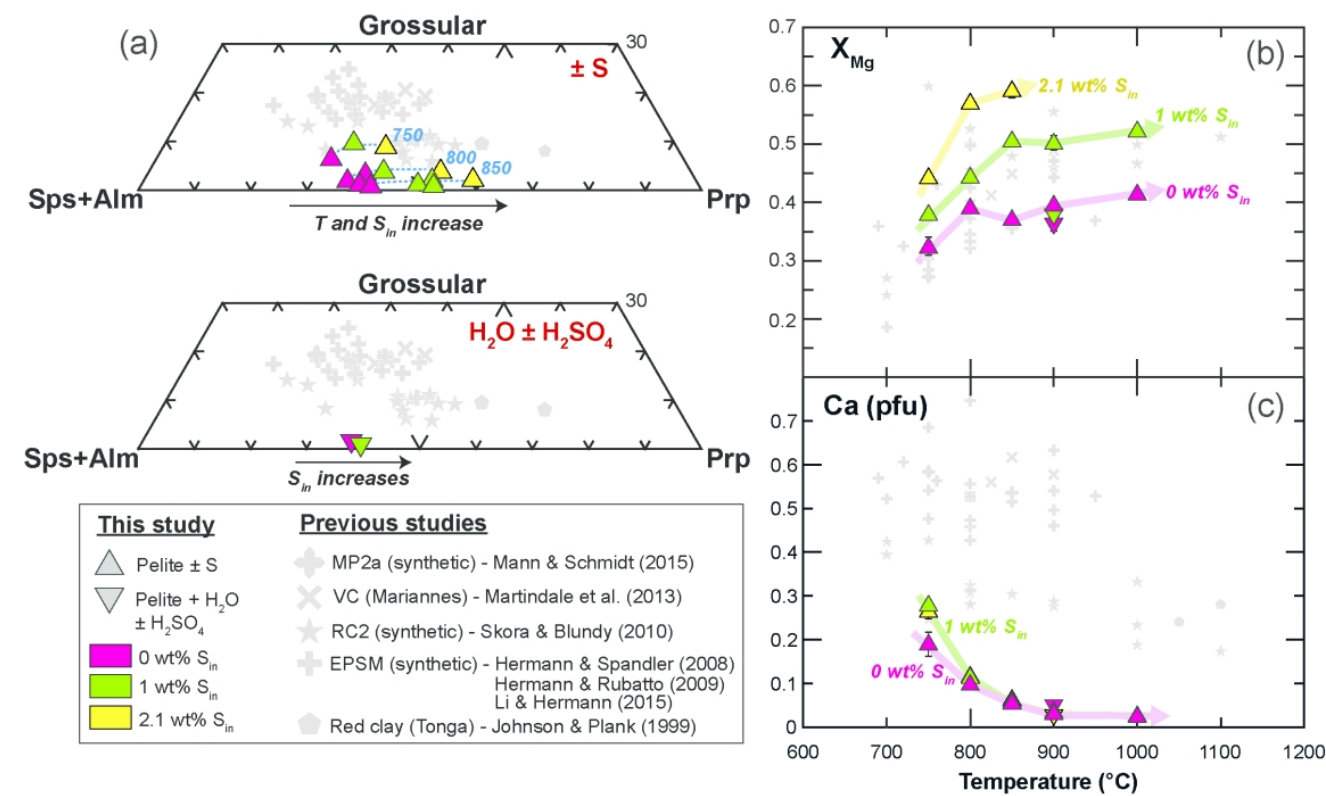

Fig. 5: (a) Garnet compositions plotted in molecular proportions of grossular (Grs), almandine (Alm), pyrope (Prp) and spessartine (Sps); (b,c) variations of $\mathrm{X}_{\mathrm{Mg}}$ and $\mathrm{Ca}$ (in cations per formula unit (pfu)) in garnet as a function of temperature. Data from previous studies are represented by grey symbols. 

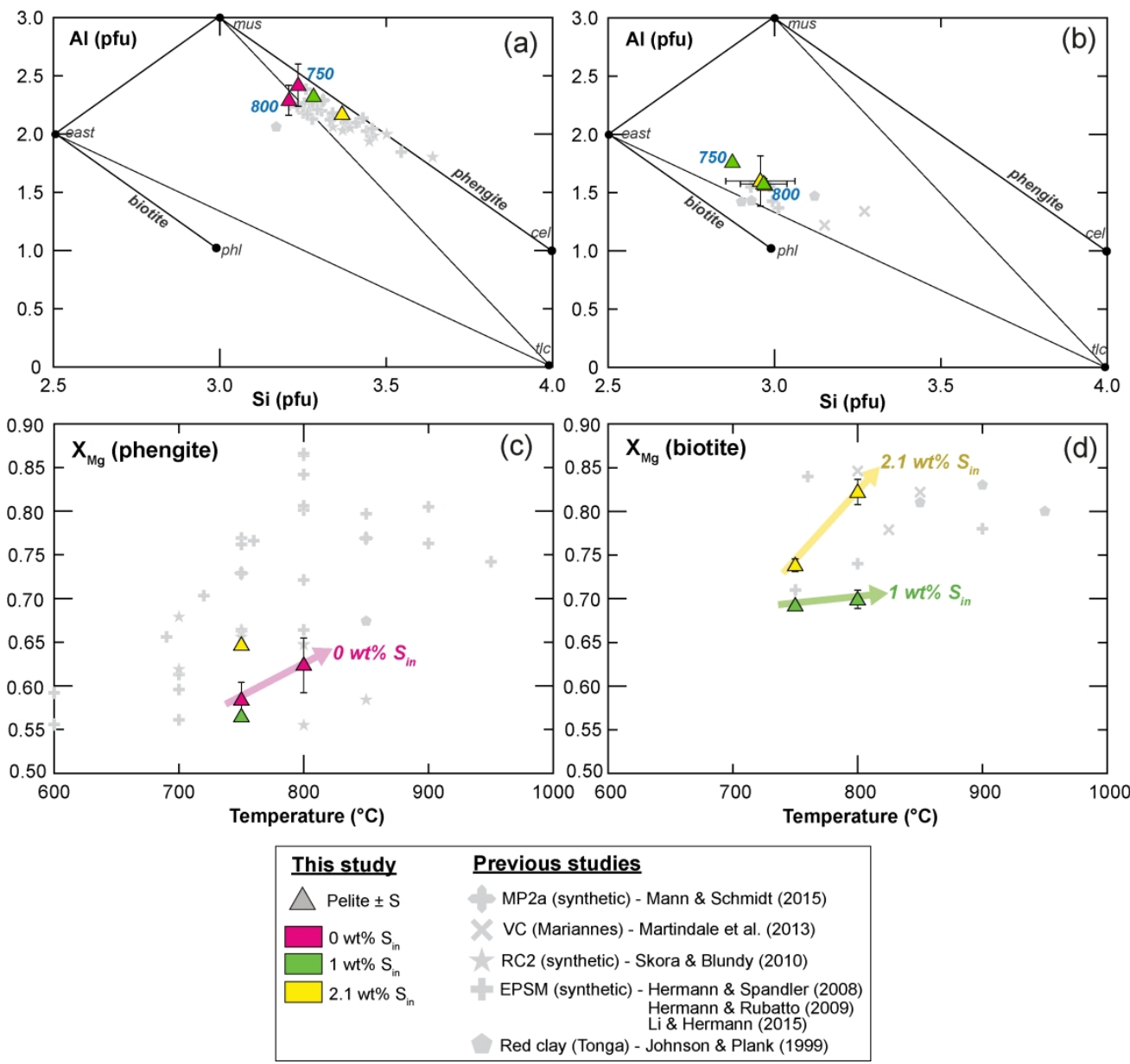

Fig. 6: Variations of Si and Al (in cations pfu) in phengite (a) and biotite (b), after Thomsen \& Schmidt (2008); variations of $\mathrm{X}_{\mathrm{Mg}}$ in phengite (c) and biotite (d) as a function of temperature. Data from previous studies are represented by grey symbols. 

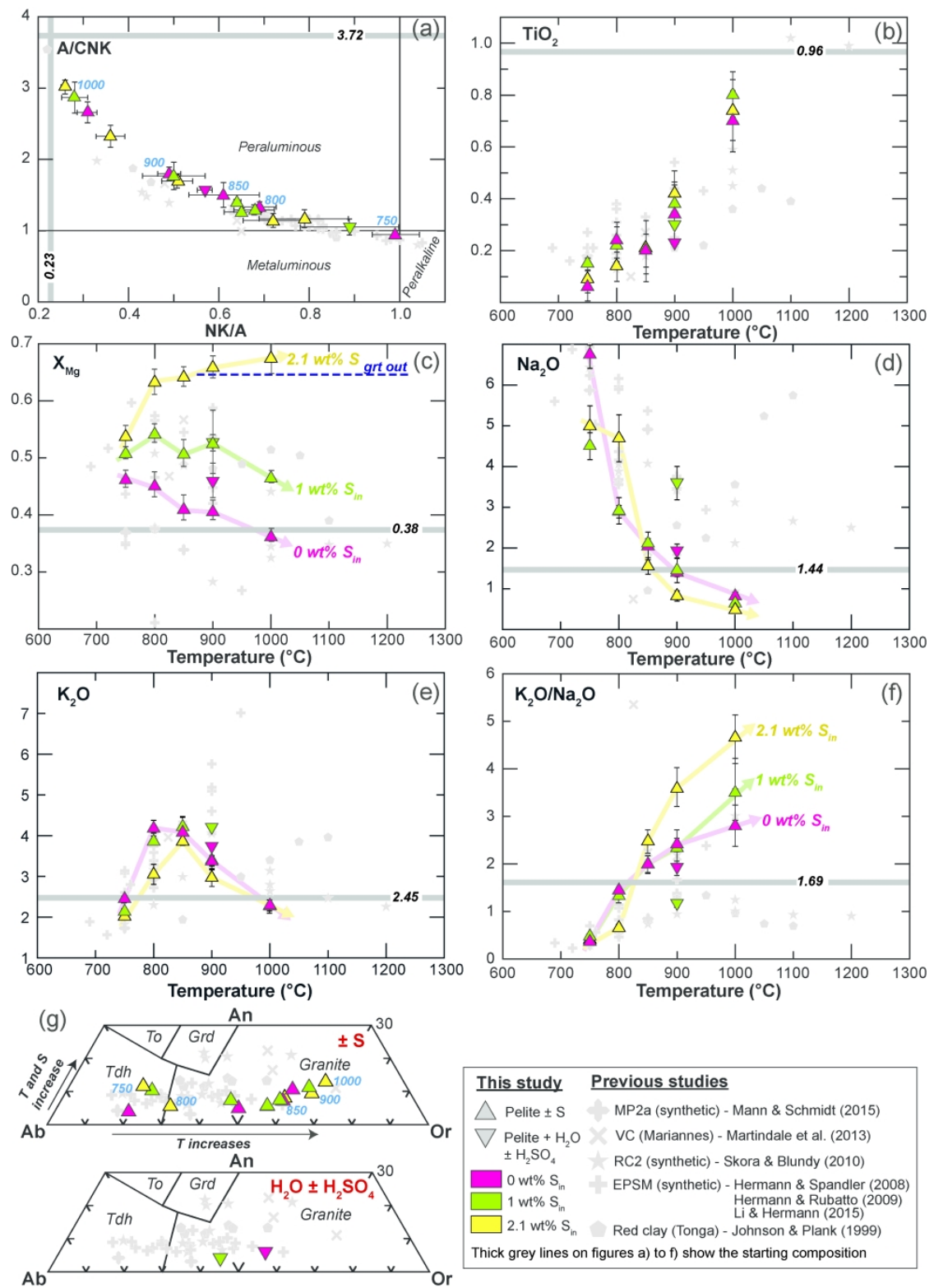

Fig. 7: Experimental glass compositions: (a) A/CNK as a function of NK/A; (b, c, d, e, f) variations of melt composition with temperature; $(\mathrm{g})$ anorthite-albite-orthoclase normative triangle; To, tonalite; Tdh, trondhjemite; Gd, granodiorite. 


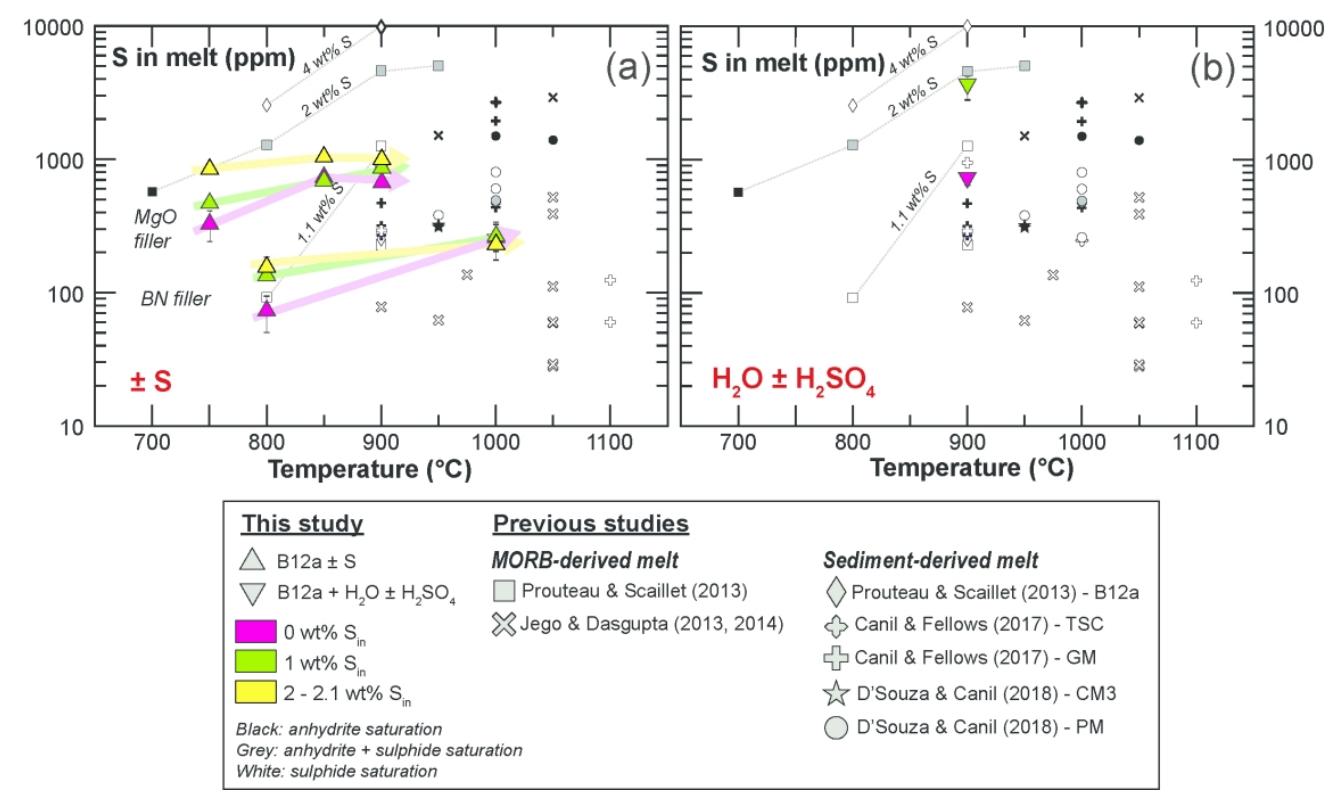

Fig. 8: Sulphur contents (ppm) of experimental glasses as a function of temperature for $\mathrm{B} 12 \mathrm{a} \pm \mathrm{S}(\mathrm{a})$ and B12a $+\mathrm{H}_{2} \mathrm{O} \pm \mathrm{H}_{2} \mathrm{SO}_{4}$ (b). Vertical bars are 1 standard deviation (when not shown error bars are smaller than the symbol size). Grey symbols show the sulphur content of experimental silicic glasses saturated in sulphide and/or sulphate at 2.3-3 GPa, 700 to $1100^{\circ} \mathrm{C}$ and $f \mathrm{O}_{2}=\mathrm{FMQ}-4$ to $\mathrm{FMQ}+3.5$ (Prouteau \& Scaillet, 2013; Jégo \& Dasgupta, 2013, 2014; Canil \& Fellows, 2017; D'Souza \& Canil, 2018).

B12a: Ca-poor pelite with 1-4 wt. \% $S_{\text {in }}$; TSC: carbonate-rich sediment with 2 wt. \% $S_{\text {in }}$; GM: Ca-rich synthetic pelite with 0.3-1 wt. \% $S_{\text {in }}$; CM3: Ca-rich pelite with 2 wt. \% $S_{\text {in }}$; PM: Fe-rich pelite with 1.9 wt. \% $\mathrm{S}_{\mathrm{in}}$. 

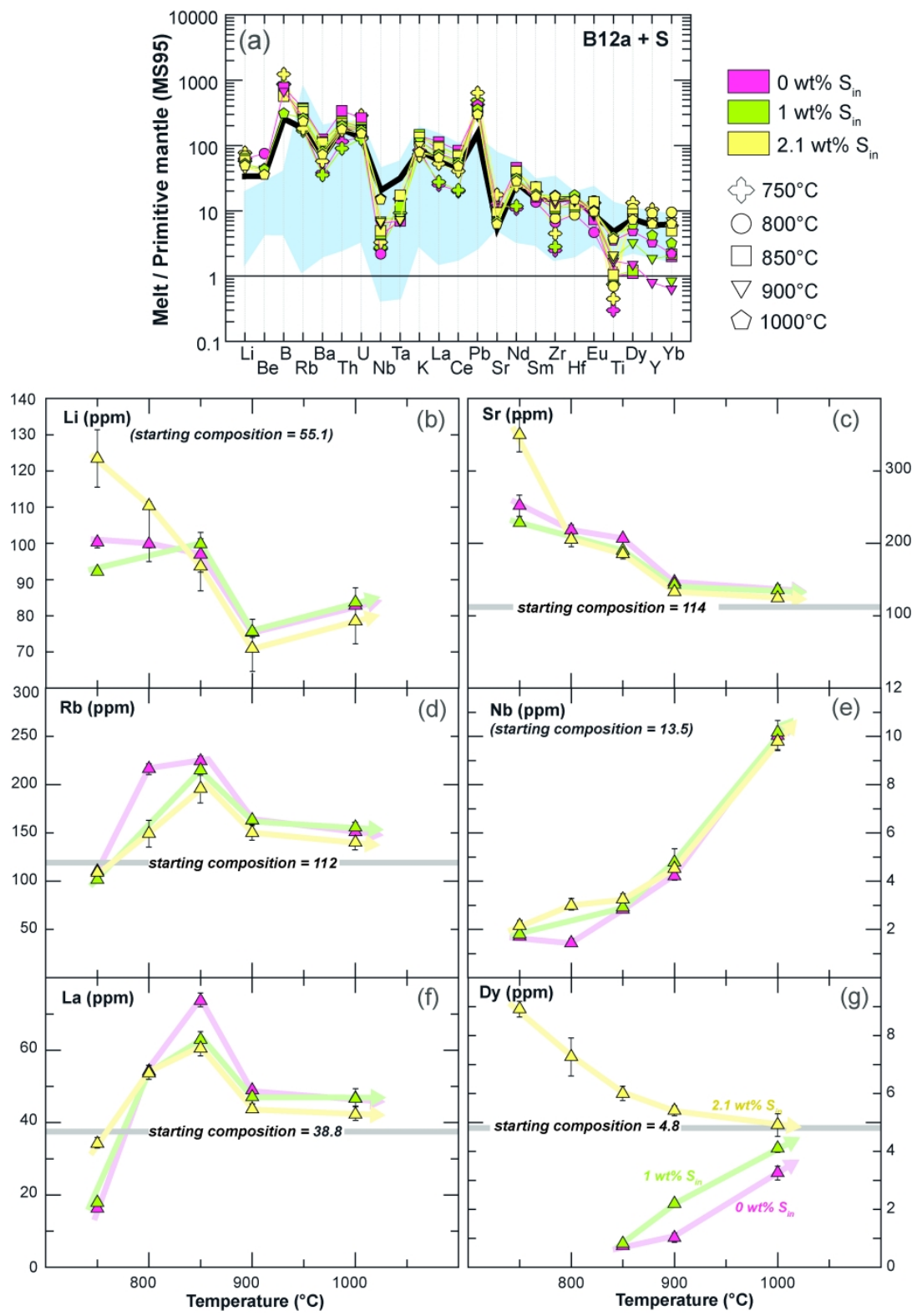

Fig. 9: (a) Trace element compositions of experimental glasses normalized to PM (McDonough \& Sun, 1995). Starting composition is shown as thick black line. Blue area corresponds to IAB with "sediment flavor" (see

Fig. 1 for details); ( $, c, d, e, f, g)$ variation of concentration of trace elements (ppm) as a function of temperature. 

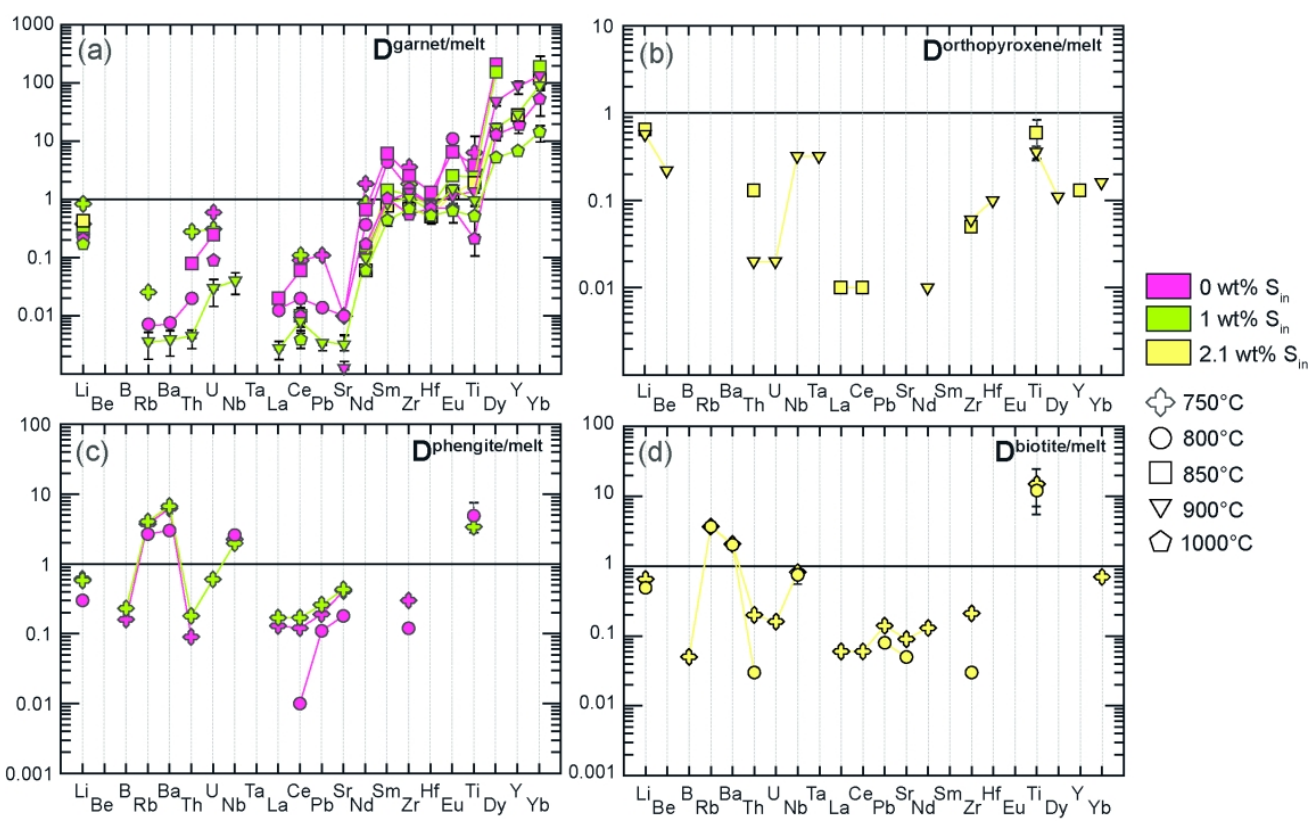

Fig. 10: Garnet-melt (a), orthopyroxene-melt (b), biotite-melt (c) and phengite-melt (d) partition coefficients for the trace elements studied. Garnet-melt partition coefficients are compared to the coefficients of Skora \& Blundy (2010) (grey area in (a)). 


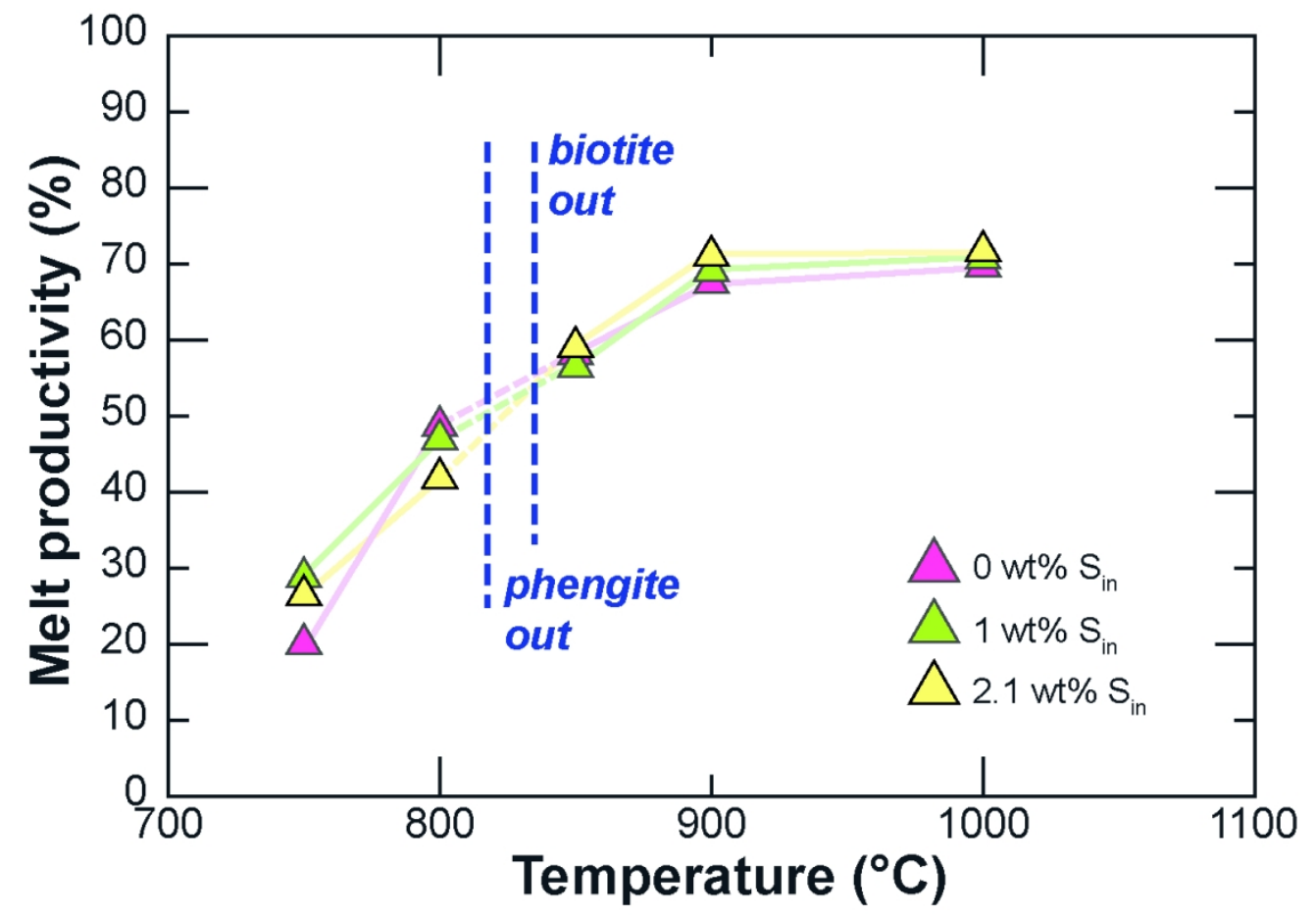

Fig. 11: Melt productivity at $3 \mathrm{GPa}$ calculated from mass balance (Table 2) as a function of temperature. 


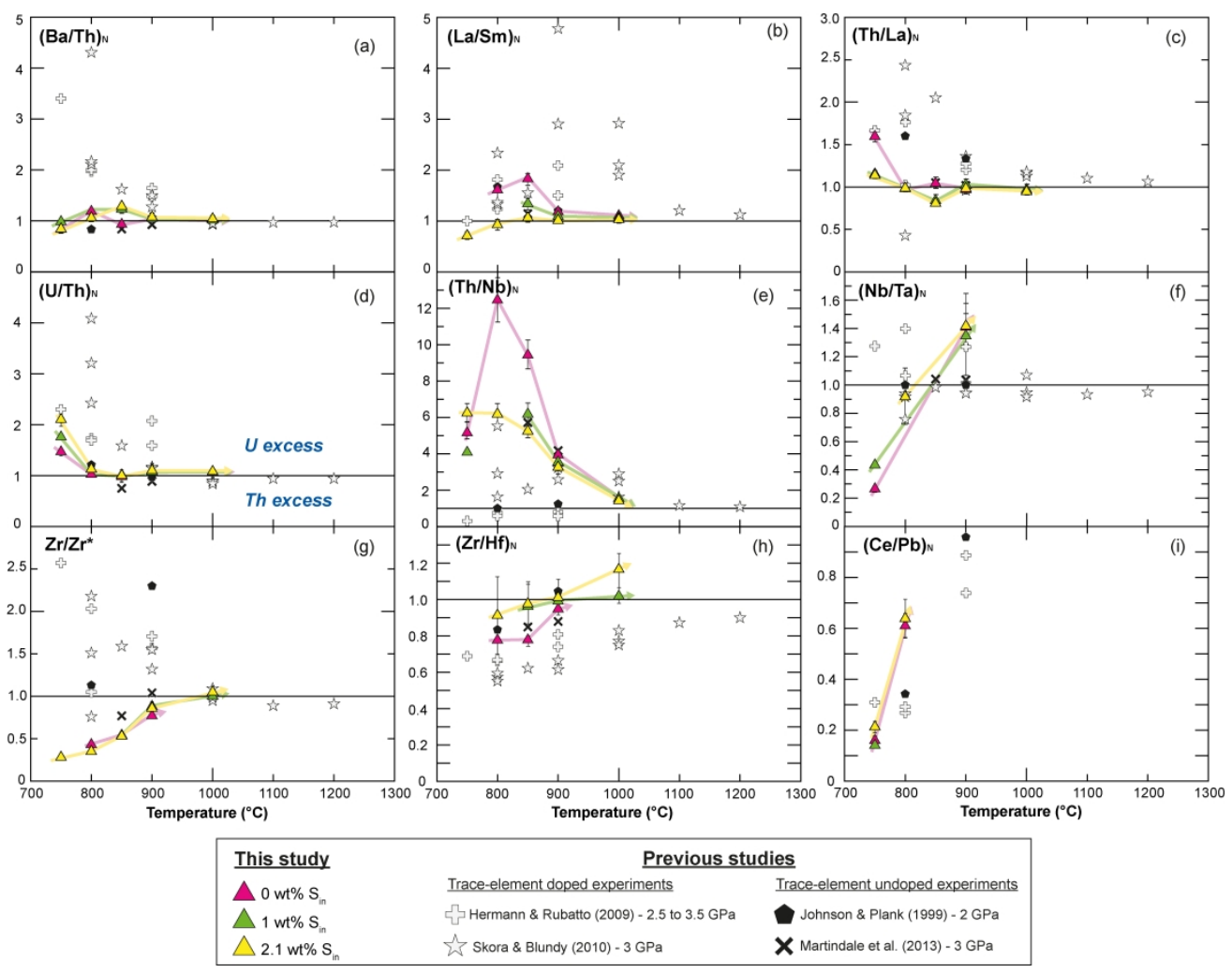

Fig. 12: Element fractionation in hydrous melts as a function of temperature. $(\mathrm{Ba} / \mathrm{Th})_{\mathrm{N}}=$ $(\mathrm{Ba} / \mathrm{Th})_{\mathrm{melt}} /(\mathrm{Ba} / \mathrm{Th})_{\text {starting material }}$ etc.

$\mathrm{Zr} / \mathrm{Zr} *=\mathrm{Zr} / 10^{((\log N d+\operatorname{logSm}) / 2)}($ McCuaig et al., 1994). 

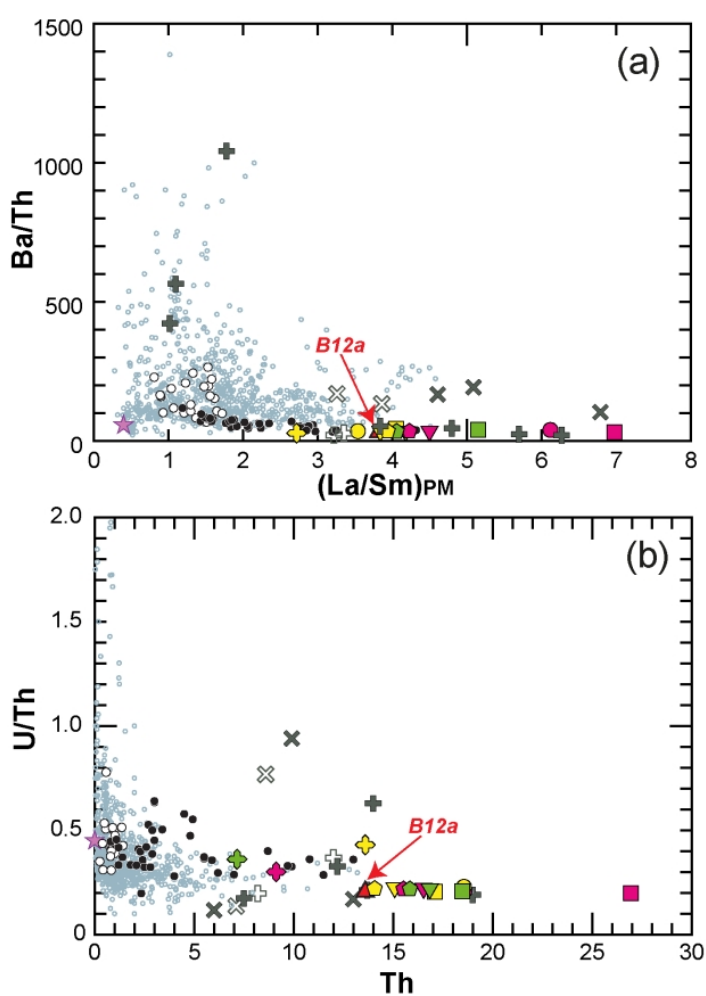

Sediment-derived experimental melts

Ca-poor pelite (this study)

$\triangle$ B12a (starting composition)

0 wt $\% \mathrm{~S}_{\text {in }}\left\{750^{\circ} \mathrm{C} \nabla 900^{\circ} \mathrm{C}\right.$

$1 \mathrm{wt} \% \mathrm{~S}_{\text {in }} \bigcirc 800^{\circ} \mathrm{C} \triangle 1000^{\circ} \mathrm{C}$

$2.1 \mathrm{wt} \% \mathrm{~S}, \quad \square 850^{\circ} \mathrm{C}$

Carbonate-bearing sediments (Skora et al., 2015, 2017)

\Ca-rich sediments (starting composition)

$\checkmark \mathrm{CaCO}_{3}$-rich sediments (starting composition)

Ca-rich sediment derived melts $\left(3 \mathrm{GPa} ; 850-1100^{\circ} \mathrm{C}\right)$

$X \mathrm{CaCO} 3$-rich sediment derived melts $\left(3 \mathrm{GPa} ; 850-1100^{\circ} \mathrm{C}\right)$

\section{Natural compositions}

\. Depleted mantle MORB (Workman \& Hart, 2005)

Worldwilde arc basalts ( $\mathrm{MgO}>6 \mathrm{wt} \%)$

GeoRoc compilation $(n=828)$

Lesser Antilles IAB (GeoRoc compilation: $\mathbf{n = 6 2}$ )

Northern and central islands

- Southern islands (Grenade and Grenadines)

Fig. 13: (a) (La/Sm) PM (McDonough \& Sun, 1995) versus Ba/Th and (b) Th versus U/Th for mafic (MgO> 6 wt. \%) arc lavas worldwilde, including the Lesser Antilles (compilation from GeoRoc: http://georoc.mpchmainz.gwdg.de; see Supplementary Data 5 for references). Superimposed are the chemical compositions of the experimental glasses of this study, as well as the experiments of Skora et al. $(2015,2017)$. 
Table 1: Starting composition in comparison with natural compositions

\begin{tabular}{|c|c|c|c|c|}
\hline & B12a & B12a $\mathbf{a}^{(1)}$ & $\begin{array}{l}\text { GLOSS- } \\
\text { II }^{(1)}\end{array}$ & $\begin{array}{l}\text { S. Ant. } \\
\text { Sed. }^{(1)}\end{array}$ \\
\hline \multicolumn{5}{|l|}{$w t \%$} \\
\hline $\mathrm{SiO}_{2}$ & 58.49 & 64.80 & 63.08 & 70.78 \\
\hline $\mathrm{TiO}_{2}$ & 0.87 & 0.96 & 0.71 & 0.79 \\
\hline $\mathrm{Al}_{2} \mathrm{O}_{3}$ & 19.35 & 21.44 & 13.94 & 13.82 \\
\hline $\mathrm{FeO}_{\text {total }}$ & 5.59 & 6.19 & 6.32 & 5.47 \\
\hline $\mathrm{FeO}$ & 1.67 & 1.85 & - & - \\
\hline $\mathrm{MnO}$ & 0.04 & 0.04 & 0.48 & 0.09 \\
\hline $\mathrm{MgO}$ & 1.95 & 2.16 & 3.06 & 2.26 \\
\hline $\mathrm{CaO}$ & 0.36 & 0.40 & 6.93 & 1.18 \\
\hline $\mathrm{Na}_{2} \mathrm{O}$ & 1.31 & 1.45 & 2.79 & 3.01 \\
\hline $\mathrm{K}_{2} \mathrm{O}$ & 2.21 & 2.45 & 2.46 & 2.18 \\
\hline $\mathrm{P}_{2} \mathrm{O}_{5}$ & 0.09 & 0.10 & 0.22 & 0.40 \\
\hline LOI & 8.53 & - & - & - \\
\hline Total & 98.79 & 100.00 & 100.00 & 100.00 \\
\hline $\mathrm{CO}_{2}$ & 1.03 & - & - & - \\
\hline $\mathrm{H}_{2} \mathrm{O}_{\text {total }}$ & 8.53 & - & - & - \\
\hline $\mathrm{H}_{2} \mathrm{O}^{-}$ & 2.53 & - & - & - \\
\hline S & 0.09 & - & - & - \\
\hline $\mathrm{F}$ & 0.056 & - & - & - \\
\hline $\mathrm{Cl}$ & 0.057 & - & - & - \\
\hline \multicolumn{5}{|c|}{ Molar ratios } \\
\hline $\mathrm{K} / \mathrm{Na}$ & - & 1.11 & 0.58 & 0.48 \\
\hline $\mathrm{A} / \mathrm{CNK}$ & - & 3.72 & 0.70 & 1.46 \\
\hline $\mathrm{NK} / \mathrm{A}$ & - & 0.23 & 0.52 & 0.53 \\
\hline $\mathrm{X}_{\mathrm{Mg}}$ & - & 0.38 & 0.46 & 0.42 \\
\hline $\mathrm{X}_{\mathrm{Ca}}$ & - & 0.05 & 0.43 & 0.14 \\
\hline
\end{tabular}

(1): volatile-free. Normalized to $100 \%$.

GLOSS-II: GLObal Subducting Sediment and. Ant. Sed.: South Antilles Sediments (Plank, 2014). LOI: Loss On Ignition.

$\mathrm{A} / \mathrm{CNK}=\mathrm{Al} /(\mathrm{Na}+\mathrm{K}+2 \mathrm{Ca}) ; \mathrm{NK} / \mathrm{A}=(\mathrm{Na}+\mathrm{K}) / \mathrm{Al} ;$

$\mathrm{X}_{\mathrm{Mg}}: \mathrm{MgO} /\left(\mathrm{MgO}_{\mathrm{FeO}}\right) ; \mathrm{X}_{\mathrm{Ca}}=\mathrm{CaO} /\left(\mathrm{CaO}+\mathrm{Mg}+\mathrm{FeO}_{\mathrm{T}}\right) ;$ all molar. 
Table 2 : Experimental conditions and phase proportions $(\mathrm{P}=3 \mathrm{GPa})$

\begin{tabular}{|c|c|c|c|c|c|c|c|c|c|c|c|c|c|c|c|c|c|c|c|c|}
\hline Run & $\begin{array}{l}\mathrm{T} \\
\left({ }^{\circ} \mathrm{C}\right)\end{array}$ & $\begin{array}{l}\text { Time } \\
\text { (hours) }\end{array}$ & Ass. & $\begin{array}{l}\mathrm{H}_{2} \mathrm{O} \\
(\mathbf{w t} \%)\end{array}$ & $\begin{array}{l}S_{\text {in }} \\
(w t \%)\end{array}$ & Runp & ducts & & & & & & & & & & & & & \\
\hline & & & & & & Melt & Grt & Opx & Ky & St & $\mathrm{Bt}$ & $\mathrm{Ph}$ & Rt & $\begin{array}{l}\text { Ti- } \\
\text { Mag }\end{array}$ & Qz & Po & $\mathrm{Cl} \mathrm{ph}$ & $\mathrm{Cb}$ & $\Sigma \mathrm{R}^{2}$ & Others \\
\hline \multicolumn{21}{|c|}{$\mathrm{B} 12 \mathrm{a}+\mathrm{H}_{2} \mathrm{O} \pm \mathrm{H}_{2} \mathrm{SO}_{4}$} \\
\hline PEL68h & 900 & 94 & $\mathrm{MgO}$ & 15.02 & 0 & 66.3 & 14.7 & - & 17.0 & $\operatorname{tr}$ & - & - & 0.8 & - & 1.3 & - & & & 1.6 & Zrn \\
\hline PEL69h & 900 & 94 & $\mathrm{MgO}$ & 15.21 & 1 & 68.7 & 10.0 & - & 19.9 & $t r$ & - & - & 0.4 & 1.0 & $t r$ & tr & & & 66.6 & $\mathrm{Zrn}$ \\
\hline \multicolumn{21}{|c|}{$B 12 a \pm$ elemental $S$} \\
\hline PEL71 & 750 & 241 & $\mathrm{MgO}$ & 8.53 & 0 & 20.0 & 8.7 & - & - & 19.2 & - & 21.5 & 0.6 & - & 30.0 & $\operatorname{tr}$ & - & - & 0.5 & Mnz, Zrn \\
\hline PEL72 & 750 & 241 & $\mathrm{MgO}$ & 8.53 & 1 & 28.7 & 4.6 & - & - & 19.6 & $\operatorname{tr}$ & 19.4 & 0.6 & - & 25.5 & 1.5 & - & - & 0.9 & Mnz, Zrn \\
\hline PEL73 & 750 & 241 & $\mathrm{MgO}$ & 8.53 & 2.1 & 26.4 & 0.4 & - & $\operatorname{tr}$ & 22.5 & 3.5 & 19.1 & 0.5 & - & 25.6 & 2.1 & - & - & 0.0 & Mnz, Zrn \\
\hline PEL50 & 800 & 196 & $\mathrm{BN}$ & 8.53 & 0 & 48.6 & 16.3 & - & 16.2 & $\operatorname{tr}$ & - & 4.4 & 0.7 & - & 13.4 & 0.4 & - & - & 0.1 & Mnz, Zrn \\
\hline PEL51 & 800 & 196 & $\mathrm{BN}$ & 8.53 & 1 & 46.9 & 7.4 & - & 20.2 & $\operatorname{tr}$ & 6.6 & - & 0.7 & - & 15.4 & 2.8 & - & - & 0.4 & Mnz, Zrn \\
\hline PEL52 & 800 & 196 & $\mathrm{BN}$ & 8.53 & 2.1 & 41.8 & $\operatorname{tr}$ & - & 21.7 & $\operatorname{tr}$ & 10.6 & - & 0.7 & - & 20.5 & 4.8 & - & - & 22.6 & Mnz, Zrn \\
\hline PEL38 & 800 & 90 & $\mathrm{BN}$ & 8.53 & 0 & 48.3 & 6.6 & - & - & 24.7 & 2.8 & - & 0.6 & - & 17.0 & $\operatorname{tr}$ & - & - & 7.6 & $\mathrm{Zrn}$ \\
\hline PEL39 & 800 & 90 & $\mathrm{BN}$ & 8.53 & 1 & 56.3 & - & - & - & 24.9 & 3.4 & - & 0.6 & - & 12.6 & 2.2 & - & - & 11 & Zrn \\
\hline PEL40 & 800 & 90 & $\mathrm{BN}$ & 8.53 & 2.1 & 47.0 & - & - & $\operatorname{tr}$ & 25.7 & 4.9 & - & 0.6 & - & 19.4 & 2.4 & - & - & 7.1 & Zrn \\
\hline PEL77 & 850 & 170 & $\mathrm{MgO}$ & 8.53 & 0 & 58.9 & 17.5 & - & 16.2 & - & - & - & 0.7 & - & 6.3 & $\operatorname{tr}$ & $<0.1$ & 0.3 & 1.4 & \\
\hline PEL78 & 850 & 170 & $\mathrm{MgO}$ & 8.53 & 1 & 57.1 & 11.7 & - & 19.2 & - & - & - & 0.7 & - & 8.7 & 2.3 & $<0.1$ & 0.4 & 0.2 & \\
\hline PEL79 & 850 & 170 & $\mathrm{MgO}$ & 8.53 & 2.1 & 60.0 & 1.2 & 4.0 & 21.1 & - & - & - & 0.8 & - & 7.9 & 4.3 & $<0.1$ & 0.7 & 0.2 & \\
\hline PEL9 & 900 & 91 & $\mathrm{MgO}$ & 8.53 & 0 & 68.1 & 14.1 & - & 16.2 & - & - & - & 0.7 & - & $\operatorname{tr}$ & 0.1 & $<0.1$ & 0.8 & 0.0 & \\
\hline PEL13 & 900 & 91 & $\mathrm{MgO}$ & 8.53 & 1 & 69.8 & 8.9 & - & 17.6 & - & - & - & 0.7 & - & $\operatorname{tr}$ & 2.3 & $<0.1$ & 0.7 & 0.0 & \\
\hline PEL14 & 900 & 91 & $\mathrm{MgO}$ & 8.53 & 2.1 & 71.8 & - & 2.3 & 19.6 & - & - & - & 0.7 & - & $\operatorname{tr}$ & 4.1 & $<0.1$ & 1.4 & 0.1 & Zrn \\
\hline PEL35 & 1000 & 93 & $\mathrm{BN}$ & 8.53 & 0 & 70.4 & 10.7 & - & 16.8 & - & - & - & 0.4 & - & - & 0.1 & $<0.1$ & 1.4 & 0.1 & \\
\hline PEL36 & 1000 & 93 & $\mathrm{BN}$ & 8.53 & 1 & 71.4 & 6.6 & - & 17.9 & - & - & - & 0.4 & - & - & 2.1 & $<0.1$ & 1.7 & 0.1 & Zrn \\
\hline PEL37 & 1000 & 93 & $\mathrm{BN}$ & 8.53 & 2.1 & 72.5 & - & - & 20.2 & - & - & - & 0.4 & - & - & 5.0 & $<0.1$ & 1.8 & 10.9 & \\
\hline
\end{tabular}

Phase proportions calculated using a least-square mass balance (Albarède, 1995). Mass balance calculations at $\mathrm{T}>850^{\circ} \mathrm{C}$ include carbonates and Cl-rich phase with putative compositions (Supplementary Data 3). $\mathrm{S}_{\text {in }}$ represents the amount of sulphur loaded to the capsule. Abbreviations: Ass.: assembly; Grt: garnet; Opx: orthopyroxene; Ky: kyanite; St: staurolite; Bt: biotite; Ph: phengite; Rt: rutile; Ti-Mag: Ti-magnetite; Qz: quartz; Po: pyrrhotite; Cl ph: Cl-rich phases; Cb: carbonate; Zrn: zircon; Mnz: monzazite; tr: traces. Mass balance calculation for PEL69h (in italics) is to consider with caution, see text. 
Table 3: Compositions of experimental glasses (normalized to $100 \mathrm{wt} \%$ anhydrous)

\begin{tabular}{|c|c|c|c|c|c|c|c|c|c|c|c|c|c|c|c|c|c|c|}
\hline Run no. & \multicolumn{2}{|l|}{ PEL71 } & \multicolumn{2}{|l|}{ PEL72 } & \multicolumn{2}{|l|}{ PEL73 } & \multicolumn{2}{|l|}{ PEL50 } & \multicolumn{2}{|l|}{ PEL51 } & \multicolumn{2}{|c|}{ PEL52 } & \multicolumn{2}{|l|}{ PEL77 } & \multicolumn{2}{|l|}{ PEL78 } & \multicolumn{2}{|c|}{ PEL79 } \\
\hline Temperature $\left({ }^{\circ} \mathrm{C}\right)$ & 750 & & 750 & & 750 & & 800 & & 800 & & 800 & & 850 & & 850 & & 850 & \\
\hline Duration (h) & 241 & & 241 & & 241 & & 196 & & 196 & & 196 & & 170 & & 170 & & 170 & \\
\hline $\mathrm{H}_{2} \mathrm{O}_{\text {in }}(\mathrm{wt} \%)$ & - & & - & & - & & - & & - & & - & & - & & - & & - & \\
\hline $\mathrm{S}_{\text {in }}(\mathrm{wt} \%)$ & - & & 1 & & 2.1 & & - & & 1 & & 2.1 & & - & & 1 & & 2.1 & \\
\hline$w t \%$ & & $s d(n=$ & & $s d(n=$ & & $s d(n=$ & & $s d(n=$ & & $s d(n=$ & & $s d(n=$ & & $s d(n=$ & & $s d(n=$ & & $s d(n=6)$ \\
\hline $\mathrm{SiO}_{2}$ & 74.69 & 0.49 & 75.35 & 0.60 & 75.03 & 0.47 & 76.52 & 0.49 & 76.84 & 0.39 & 75.35 & 1.07 & 77.90 & 0.58 & 77.83 & 0.30 & 77.30 & 0.38 \\
\hline $\mathrm{TiO}_{2}$ & 0.06 & 0.06 & 0.14 & 0.03 & 0.09 & 0.06 & 0.24 & 0.07 & 0.22 & 0.07 & 0.14 & 0.06 & 0.20 & 0.12 & 0.20 & 0.06 & 0.21 & 0.10 \\
\hline $\mathrm{Al}_{2} \mathrm{O}_{3}$ & 13.83 & 0.29 & 14.72 & 0.41 & 14.41 & 0.44 & 13.46 & 0.47 & 13.15 & 0.17 & 14.05 & 0.88 & 12.79 & 0.14 & 12.53 & 0.20 & 13.30 & 0.24 \\
\hline $\mathrm{FeO}$ & 1.12 & 0.12 & 1.16 & 0.07 & 1.16 & 0.12 & 1.42 & 0.11 & 1.26 & 0.14 & 0.98 & 0.09 & 1.73 & 0.11 & 1.58 & 0.14 & 1.51 & 0.10 \\
\hline $\mathrm{MnO}$ & 0.01 & 0.01 & 0.07 & 0.05 & 0.07 & 0.10 & 0.06 & 0.05 & 0.05 & 0.07 & 0.06 & 0.06 & 0.02 & 0.04 & 0.04 & 0.04 & 0.04 & 0.06 \\
\hline $\mathrm{MgO}$ & 0.54 & 0.04 & 0.67 & 0.02 & 0.75 & 0.07 & 0.65 & 0.04 & 0.83 & 0.07 & 0.94 & 0.06 & 0.67 & 0.02 & 0.91 & 0.03 & 1.51 & 0.05 \\
\hline $\mathrm{CaO}$ & 0.56 & 0.05 & 1.19 & 0.03 & 1.41 & 0.09 & 0.50 & 0.06 & 0.75 & 0.05 & 0.67 & 0.02 & 0.48 & 0.03 & 0.51 & 0.03 & 0.63 & 0.03 \\
\hline $\mathrm{Na}_{2} \mathrm{O}$ & 6.72 & 0.33 & 4.45 & 0.34 & 4.96 & 0.50 & 2.90 & 0.16 & 2.92 & 0.33 & 4.70 & 0.59 & 2.05 & 0.35 & 2.12 & 0.12 & 1.56 & 0.21 \\
\hline $\mathrm{K}_{2} \mathrm{O}$ & 2.42 & 0.08 & 2.10 & 0.10 & 1.98 & 0.07 & 4.18 & 0.16 & 3.86 & 0.11 & 3.05 & 0.25 & 4.08 & 0.35 & 4.22 & 0.19 & 3.86 & 0.13 \\
\hline $\mathrm{P}_{2} \mathrm{O}_{5}$ & 0.06 & 0.05 & 0.15 & 0.09 & 0.14 & 0.11 & 0.07 & 0.08 & 0.10 & 0.08 & 0.06 & 0.06 & 0.07 & 0.04 & 0.06 & 0.06 & 0.07 & 0.06 \\
\hline Hydrous total & 91.95 & 0.32 & 90.45 & 1.02 & 90.93 & 0.43 & 90.35 & 0.65 & 88.40 & 1.05 & 90.23 & 1.02 & 89.64 & 1.45 & 90.13 & 0.65 & 88.60 & 0.96 \\
\hline $\mathrm{H}_{2} \mathrm{O}_{\text {by diff. }}$ & 7.2 & 0.3 & 7.3 & 0.9 & 6.7 & 0.7 & 8.4 & 0.6 & 11.0 & 1.0 & 9.4 & 1.1 & 10.2 & 1.4 & 9.7 & 0.6 & 11.2 & 0.9 \\
\hline $\mathrm{H}_{2} \mathrm{O}_{\text {calc. }}$ & 36.4 & 2.9 & 25.6 & 2.0 & 27.2 & 2.4 & 17.1 & 0.2 & 17.5 & 0.3 & 19.3 & 0.5 & 14.4 & 0.1 & 15.4 & 0.1 & 14.1 & 0.1 \\
\hline S melt (ppm) & 322 & 86 & 461 & 36 & 829 & 49 & 72 & 28 & 132 & 33 & 153 & 30 & 728 & 34 & 685 & 27 & 1033 & 42 \\
\hline $\mathrm{n}(\mathrm{S})$ & 7 & - & 6 & - & 6 & - & 8 & - & 7 & - & 7 & - & 7 & - & 7 & - & 7 & - \\
\hline $\mathrm{X}_{\mathrm{Mg}}$ & 0.46 & 0.02 & 0.51 & 0.01 & 0.54 & 0.02 & 0.45 & 0.02 & 0.54 & 0.02 & 0.63 & 0.02 & 0.41 & 0.02 & 0.51 & 0.02 & 0.64 & 0.02 \\
\hline $\mathrm{X}_{\mathrm{Ca}}$ & 0.26 & 0.02 & 0.39 & 0.02 & 0.42 & 0.03 & 0.20 & 0.02 & 0.26 & 0.02 & 0.24 & 0.01 & 0.17 & 0.01 & 0.17 & 0.00 & 0.16 & 0.01 \\
\hline $\mathrm{A} / \mathrm{CNK}$ & 0.94 & 0.05 & 1.25 & 0.06 & 1.13 & 0.10 & 1.32 & 0.08 & 1.28 & 0.08 & 1.16 & 0.13 & 1.49 & 0.18 & 1.39 & 0.02 & 1.69 & 0.11 \\
\hline NK/A & 0.99 & 0.05 & 0.65 & 0.04 & 0.72 & 0.07 & 0.69 & 0.04 & 0.68 & 0.05 & 0.79 & 0.10 & 0.61 & 0.08 & 0.64 & 0.01 & 0.51 & 0.04 \\
\hline $\mathrm{K} / \mathrm{Na}$ & 0.24 & 0.01 & 0.31 & 0.03 & 0.27 & 0.02 & 0.95 & 0.05 & 0.88 & 0.11 & 0.43 & 0.05 & 1.32 & 0.12 & 1.31 & 0.13 & 1.64 & 0.17 \\
\hline $\mathrm{Ab} \%$ & 76.95 & - & 67.32 & - & 69.15 & - & 47.43 & - & 48.26 & - & 65.10 & - & 39.64 & - & 39.54 & - & 33.80 & - \\
\hline $\mathrm{An} \%$ & 3.74 & - & 10.53 & - & 11.53 & - & 4.80 & - & 7.24 & - & 5.43 & - & 5.46 & - & 5.60 & - & 8.02 & - \\
\hline $\mathrm{Or} \%$ & 19.31 & - & 22.144 & - & 19.325 & - & 47.77 & - & 44.503 & - & 29.47 & - & 54.9 & - & 54.86 & - & 58.17 & - \\
\hline
\end{tabular}


Table 3, continued

\begin{tabular}{|c|c|c|c|c|c|c|c|c|c|c|c|c|c|c|c|c|}
\hline Run no. & \multicolumn{2}{|l|}{ PEL9 } & \multicolumn{2}{|c|}{ PEL13 } & \multicolumn{2}{|l|}{ PEL14 } & \multicolumn{2}{|c|}{ PEL35 } & \multicolumn{2}{|c|}{ PEL36 } & \multicolumn{2}{|c|}{ PEL37 } & \multicolumn{2}{|c|}{ PEL68H } & \multicolumn{2}{|c|}{ PEL69H } \\
\hline Temperature $\left({ }^{\circ} \mathrm{C}\right)$ & 900 & & \multicolumn{2}{|l|}{900} & \multicolumn{2}{|l|}{900} & \multicolumn{2}{|l|}{1000} & \multicolumn{2}{|l|}{1000} & \multicolumn{2}{|c|}{1000} & \multicolumn{2}{|c|}{900} & \multicolumn{2}{|c|}{900} \\
\hline Duration (h) & \multicolumn{2}{|l|}{91} & \multicolumn{2}{|l|}{91} & \multicolumn{2}{|l|}{91} & \multicolumn{2}{|l|}{93} & \multicolumn{2}{|l|}{93} & \multicolumn{2}{|l|}{93} & \multicolumn{2}{|l|}{94} & \multicolumn{2}{|l|}{94} \\
\hline $\mathrm{H}_{2} \mathrm{O}_{\text {in }}(\mathrm{wt} \%)$ & \multicolumn{2}{|l|}{-} & \multicolumn{2}{|l|}{-} & \multicolumn{2}{|l|}{-} & - & & - & & - & & 6.5 & & 6.7 & \\
\hline $\mathrm{S}_{\text {in }}(\mathrm{wt} \%)$ & - & & 1 & & 2.1 & & - & & 1 & & 2.1 & & - & & 1 & \\
\hline$w t \%$ & & $s d(n=$ & & $s d(n$ & & $s d(n=$ & & $s d(n=$ & & $s d(n$ & & $s d(n=$ & & $s d(n$ & & $s d(n=5)$ \\
\hline $\mathrm{SiO}_{2}$ & 78.03 & 0.26 & 78.13 & 0.63 & 78.14 & 0.49 & 77.49 & 0.28 & 77.93 & 0.09 & 78.55 & 0.35 & 78.13 & 0.59 & 74.32 & 1.33 \\
\hline $\mathrm{TiO}_{2}$ & 0.34 & 0.12 & 0.38 & 0.08 & 0.42 & 0.09 & 0.70 & 0.12 & 0.80 & 0.09 & 0.74 & 0.12 & 0.23 & 0.06 & 0.30 & 0.04 \\
\hline $\mathrm{Al}_{2} \mathrm{O}_{3}$ & 12.26 & 0.23 & 12.25 & 0.15 & 12.70 & 0.19 & 12.48 & 0.14 & 12.55 & 0.14 & 12.73 & 0.16 & 12.28 & 0.20 & 12.05 & 0.19 \\
\hline $\mathrm{FeO}$ & 2.87 & 0.17 & 2.33 & 0.14 & 2.06 & 0.19 & 4.30 & 0.08 & 3.48 & 0.20 & 2.13 & 0.32 & 2.07 & 0.31 & 2.91 & 0.66 \\
\hline $\mathrm{MnO}$ & 0.02 & 0.03 & 0.06 & 0.08 & 0.05 & 0.08 & 0.04 & 0.05 & 0.09 & 0.07 & 0.01 & 0.02 & 0.01 & 0.02 & 0.03 & 0.07 \\
\hline $\mathrm{MgO}$ & 1.10 & 0.03 & 1.44 & 0.03 & 2.22 & 0.06 & 1.36 & 0.05 & 1.69 & 0.05 & 2.45 & 0.08 & 0.98 & 0.09 & 1.84 & 0.51 \\
\hline $\mathrm{CaO}$ & 0.49 & 0.02 & 0.52 & 0.04 & 0.51 & 0.04 & 0.48 & 0.01 & 0.48 & 0.04 & 0.52 & 0.02 & 0.49 & 0.03 & 0.47 & 0.05 \\
\hline $\mathrm{Na}_{2} \mathrm{O}$ & 1.40 & 0.11 & 1.46 & 0.32 & 0.83 & 0.14 & 0.82 & 0.11 & 0.65 & 0.13 & 0.49 & 0.05 & 1.94 & 0.19 & 3.61 & 0.42 \\
\hline $\mathrm{K}_{2} \mathrm{O}$ & 3.37 & 0.13 & 3.40 & 0.25 & 2.97 & 0.22 & 2.29 & 0.17 & 2.27 & 0.18 & 2.28 & 0.11 & 3.74 & 0.22 & 4.21 & 0.24 \\
\hline $\mathrm{P}_{2} \mathrm{O}_{5}$ & 0.12 & 0.07 & 0.04 & 0.03 & 0.10 & 0.06 & 0.05 & 0.01 & 0.07 & 0.05 & 0.08 & 0.06 & 0.13 & 0.14 & 0.25 & 0.28 \\
\hline Hydrous total & 86.74 & 0.90 & 86.76 & 0.80 & 84.99 & 1.05 & 85.81 & 0.96 & 85.60 & 0.61 & 84.50 & 0.51 & 88.39 & 1.54 & 88.10 & 0.50 \\
\hline $\mathrm{H}_{2} \mathrm{O}_{\text {by diff. }}$ & 12.6 & 1.0 & 11.4 & 0.7 & 13.7 & 1.1 & 12.7 & 0.8 & 13.0 & 0.5 & 14.0 & 0.4 & 10.9 & 1.2 & 10.9 & 0.7 \\
\hline $\mathrm{H}_{2} \mathrm{O}_{\text {calc. }}$ & 12.4 & 0.1 & 12.2 & 0.1 & 11.7 & 0.1 & 12.1 & 0.1 & 11.9 & 0.1 & 11.8 & 0.1 & 22.7 & - & 22.1 & - \\
\hline S melt (ppm) & 658 & 7 & 849 & 42 & 980 & 27 & 254 & 82 & 261 & 61 & 226 & 27 & 698 & 54 & 3507 & 607 \\
\hline $\mathrm{n}(\mathrm{S})$ & 9 & - & 9 & - & 9 & - & 8 & - & 7 & - & 8 & - & 8 & - & 4 & - \\
\hline $\mathrm{X}_{\mathrm{Mg}}$ & 0.41 & 0.02 & 0.52 & 0.02 & 0.66 & 0.02 & 0.36 & 0.01 & 0.46 & 0.01 & 0.67 & 0.03 & 0.46 & 0.03 & 0.53 & 0.06 \\
\hline $\mathrm{X}_{\mathrm{Ca}}$ & 0.12 & 0.01 & 0.12 & 0.01 & 0.10 & 0.01 & 0.08 & 0.00 & 0.09 & 0.00 & 0.09 & 0.00 & 0.14 & 0.02 & 0.10 & 0.02 \\
\hline $\mathrm{A} / \mathrm{CNK}$ & 1.79 & 0.10 & 1.76 & 0.20 & 2.32 & 0.16 & 2.66 & 0.15 & 2.87 & 0.22 & 3.02 & 0.10 & 1.57 & 0.05 & 1.05 & 0.12 \\
\hline NK/A & 0.49 & 0.03 & 0.50 & 0.07 & 0.36 & 0.03 & 0.31 & 0.02 & 0.28 & 0.03 & 0.26 & 0.01 & 0.57 & 0.02 & 0.89 & 0.11 \\
\hline $\mathrm{K} / \mathrm{Na}$ & 1.59 & 0.10 & 1.57 & 0.24 & 2.41 & 0.28 & 1.86 & 0.30 & 2.38 & 0.44 & 3.08 & 0.35 & 1.33 & 0.11 & 0.76 & 0.05 \\
\hline $\mathrm{Ab} \%$ & 34.65 & - & 35.33 & - & 25.82 & - & 30.42 & - & 25.71 & - & 20.54 & - & 40.09 & - & 52.89 & - \\
\hline $\mathrm{An} \%$ & 7.15 & - & 7.32 & - & 9.32 & - & 10.46 & - & 11.16 & - & 12.83 & - & 5.92 & - & 4.03 & - \\
\hline Or $\%$ & 58.19 & - & 57.35 & - & 64.86 & - & 59.13 & - & 63.12 & - & 66.63 & - & 53.99 & - & 43.08 & - \\
\hline
\end{tabular}

$\mathrm{H}_{2} \mathrm{O}_{\text {in }}$ and $\mathrm{S}_{\text {in }}$ represent the amounts of water and sulphur loaded to the capsule, respectively. sd: 1 sigma standard deviation on multiple analyses (number of analyses given in brackets); $\mathrm{n}(\mathrm{S})$ : number of analyses of sulphur. $\mathrm{H}_{2} \mathrm{O}$ estimated by the by-difference method ( $\mathrm{H}_{2} \mathrm{O}_{\text {by diff.) }}$ or by massbalance constraints $\left(\mathrm{H}_{2} \mathrm{O}_{\text {calc. }}\right)$ 
Table 4: Trace element compositions of starting material B12a and experimental glasses

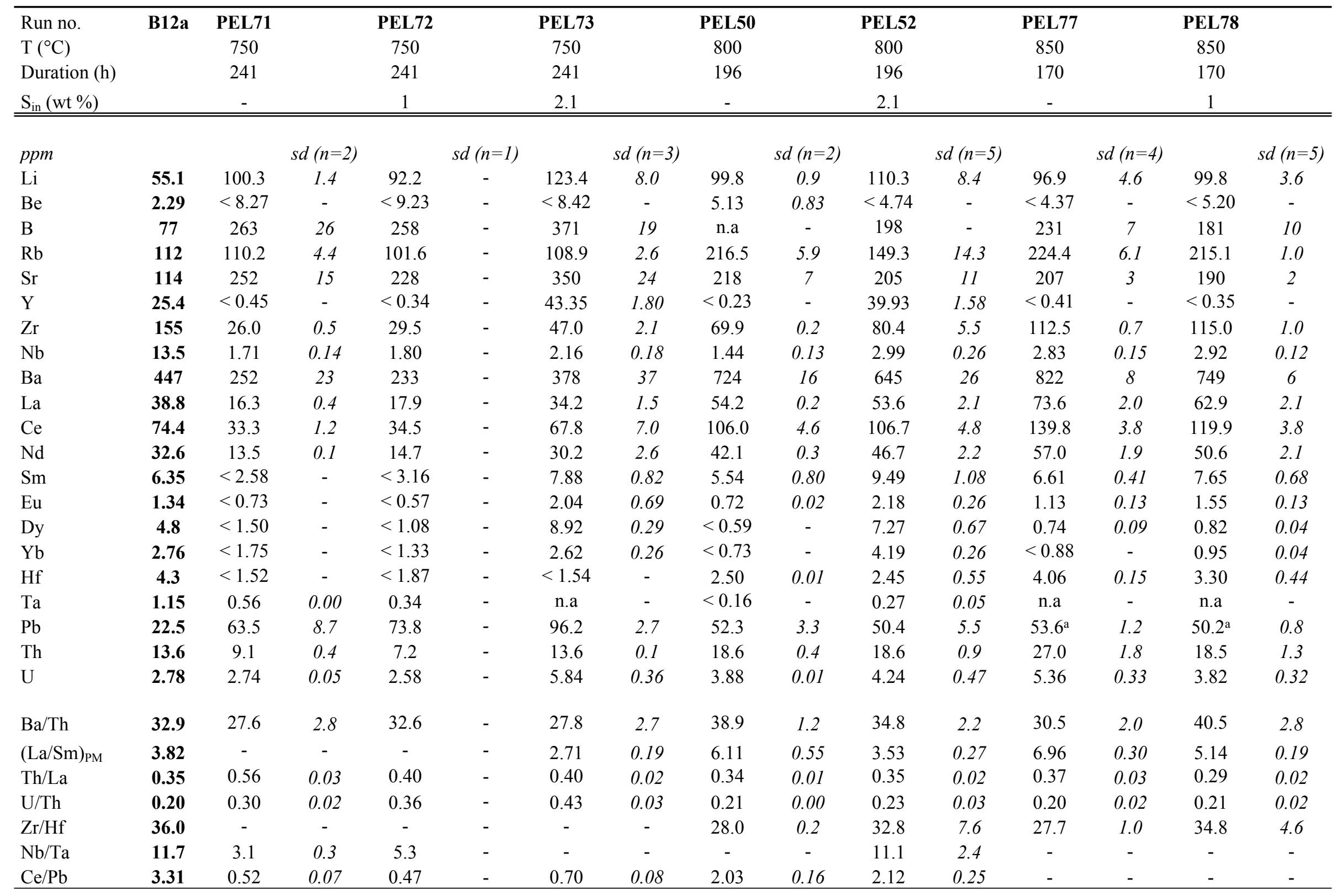


Table 4, continued

\begin{tabular}{|c|c|c|c|c|c|c|c|c|c|c|c|c|c|c|}
\hline Run no. & PEL79 & & PEL9 & & PEL13 & & PEL14 & & PEL35 & & \multicolumn{2}{|l|}{ PEL36 } & \multicolumn{2}{|l|}{ PEL37 } \\
\hline $\mathrm{T}\left({ }^{\circ} \mathrm{C}\right)$ & 850 & & 900 & & 900 & & 900 & & 1000 & & 1000 & & \multicolumn{2}{|l|}{1000} \\
\hline Duration (h) & 170 & & 91 & & 91 & & 91 & & 93 & & 93 & & 93 & \\
\hline $\mathrm{S}_{\text {in }}(\mathrm{wt} \%)$ & 2.10 & & - & & 1 & & 2.1 & & - & & 1 & & 2.1 & \\
\hline ppm & & $s d(n=5$ & & $s d(n=7$ & & $s d(n=$ & & $s d(n=c$ & & $s d(n=$ & & $s d(n=$ & & $s d(n=4)$ \\
\hline $\mathrm{Li}$ & 93.6 & 6.4 & 75.3 & 4.2 & 75.5 & 1.5 & 70.9 & 6.0 & 82.8 & 5.2 & 83.6 & 0.6 & 78.4 & 6.0 \\
\hline $\mathrm{Be}$ & $<4.01$ & - & 2.96 & 0.21 & 2.96 & 0.24 & 2.72 & 0.33 & 2.99 & 0.36 & 2.93 & 0.27 & 2.42 & 0.66 \\
\hline B & 171 & 15 & 204 & 47 & n.a & - & n.a & - & n.a & - & 93 & 10 & n.a & - \\
\hline $\mathrm{Rb}$ & 195.9 & 14.9 & 162.9 & 4.5 & 163.4 & 1.2 & 150.3 & 8.0 & 151.0 & 10.7 & 155.7 & 2.3 & 140.1 & 8.0 \\
\hline $\mathrm{Sr}$ & 185 & 8 & 147 & 2 & 143 & 0 & 133 & 3 & 136 & 7 & 135 & 2 & 124 & 6 \\
\hline Y & 28.97 & 1.28 & 3.39 & 0.85 & 8.23 & 0.70 & 27.53 & 0.53 & 14.12 & 0.83 & 18.65 & 0.50 & 25.44 & 1.17 \\
\hline $\mathrm{Zr}$ & 122.9 & 6.2 & 138.7 & 2.1 & 161.7 & 2.3 & 152.2 & 11.2 & n.a & - & 180.0 & 2.9 & 174.5 & 7.9 \\
\hline $\mathrm{Nb}$ & 3.25 & 0.19 & 4.21 & 0.24 & 4.78 & 0.55 & 4.52 & 0.34 & 10.03 & 0.62 & 10.16 & 0.12 & 9.79 & 0.42 \\
\hline $\mathrm{Ba}$ & 725 & 29 & 583 & 9 & 581 & 3 & 531 & 11 & 525 & 28 & 528 & 6 & 479 & 24 \\
\hline $\mathrm{La}$ & 60.5 & 2.4 & 48.9 & 0.8 & 47.0 & 0.3 & 43.7 & 1.3 & 46.7 & 2.5 & 46.6 & 0.3 & 42.2 & 2.0 \\
\hline $\mathrm{Ce}$ & 115.6 & 4.4 & 97.9 & 1.0 & 97.1 & 0.6 & 89.7 & 2.6 & 88.5 & 4.5 & 88.7 & 0.6 & 80.7 & 3.9 \\
\hline $\mathrm{Nd}$ & 49.9 & 2.1 & 41.0 & 0.6 & 41.0 & 0.3 & 38.1 & 1.4 & 38.6 & 2.4 & 38.7 & 0.3 & 35.2 & 1.5 \\
\hline $\mathrm{Sm}$ & 9.35 & 0.61 & 6.81 & 0.19 & 7.05 & 0.20 & 7.14 & 0.33 & 6.91 & 0.25 & 7.19 & 0.28 & 6.72 & 0.41 \\
\hline $\mathrm{Eu}$ & 2.10 & 0.07 & 1.32 & 0.03 & 1.39 & 0.05 & 1.47 & 0.07 & 1.52 & 0.10 & 1.54 & 0.04 & 1.49 & 0.14 \\
\hline Dy & 6.00 & 0.26 & 1.02 & 0.17 & 2.20 & 0.13 & 5.41 & 0.19 & 3.26 & 0.25 & 4.11 & 0.15 & 4.92 & 0.41 \\
\hline $\mathrm{Yb}$ & 2.18 & 0.42 & 0.28 & 0.11 & 0.37 & 0.10 & 3.09 & 0.13 & 0.97 & 0.16 & 1.40 & 0.16 & 2.80 & 0.21 \\
\hline Hf & 3.50 & 0.35 & 4.02 & 0.09 & 4.54 & 0.13 & 4.18 & 0.27 & 4.56 & 0.21 & 4.89 & 0.19 & 4.18 & 0.28 \\
\hline Та & n.a & - & 0.26 & 0.01 & 0.30 & 0.05 & 0.27 & 0.02 & $\mathrm{n} . \mathrm{a}$ & - & n.a & - & n.a & - \\
\hline $\mathrm{Pb}$ & $54.3^{\mathrm{a}}$ & 4.0 & $43.2^{\mathrm{a}}$ & 1.9 & $44.5^{\mathrm{a}}$ & 0.4 & $45.8^{\mathrm{a}}$ & 1.6 & $63.0^{\mathrm{a}}$ & 4.7 & $53.8^{\mathrm{a}}$ & 0.9 & $45.0^{\mathrm{a}}$ & 3.2 \\
\hline Th & 17.1 & 0.6 & 16.5 & 0.6 & 16.8 & 0.5 & 15.1 & 1.4 & 15.5 & 0.8 & 15.8 & 0.1 & 14.1 & 0.7 \\
\hline $\mathrm{U}$ & 3.51 & 0.13 & 3.66 & 0.08 & 3.70 & 0.09 & 3.39 & 0.33 & 3.38 & 0.18 & 3.44 & 0.02 & 3.09 & 0.19 \\
\hline $\mathrm{Ba} / \mathrm{Th}$ & 42.4 & 2.3 & 35.2 & 1.3 & 34.5 & 1.0 & 35.3 & 3.4 & 33.8 & 2.6 & 33.3 & 0.5 & 34.1 & 2.5 \\
\hline$(\mathrm{La} / \mathrm{Sm})_{\mathrm{PM}}$ & 4.04 & 0.09 & 4.49 & 0.09 & 4.17 & 0.07 & 3.83 & 0.13 & 4.22 & 0.17 & 4.05 & 0.10 & 3.93 & 0.19 \\
\hline $\mathrm{Th} / \mathrm{La}$ & 0.28 & 0.02 & 0.34 & 0.01 & 0.36 & 0.01 & 0.35 & 0.03 & 0.33 & 0.03 & 0.34 & 0.00 & 0.33 & 0.02 \\
\hline $\mathrm{U} / \mathrm{Th}$ & 0.21 & 0.01 & 0.22 & 0.01 & 0.22 & 0.01 & 0.22 & 0.03 & 0.22 & 0.02 & 0.22 & 0.00 & 0.22 & 0.02 \\
\hline $\mathrm{Zr} / \mathrm{Hf}$ & 35.1 & 3.9 & 34.5 & 1.0 & 35.7 & 1.2 & 36.4 & 3.5 & - & - & 36.8 & 1.6 & 41.7 & 3.4 \\
\hline $\mathrm{Nb} / \mathrm{Ta}$ & - & - & 16.4 & 1.3 & 16.0 & 3.4 & 16.7 & 1.9 & - & - & - & - & - & - \\
\hline $\mathrm{Ce} / \mathrm{Pb}$ & - & - & - & - & - & - & - & - & - & - & - & - & - & - \\
\hline
\end{tabular}

n.a: not analysed. sd: 1 sigma standard deviation on multiple analyses (number of analyses given in brackets). $(\mathrm{La} / \mathrm{Sm})_{\mathrm{PM}}=\mathrm{La} / \mathrm{Sm}$ ratio normalized to the primitive mantle (McDonough \& Sun, 1995). ${ }^{\mathrm{a} P b}$ contamination suspected (see text). 
Table 5: Garnet-melt partition coefficients

\begin{tabular}{|c|c|c|c|c|c|c|c|c|c|c|c|c|c|c|c|c|c|c|c|c|}
\hline Run no. & PEL71 & & PEL72 & & PEL50 & & PEL77 & & PEL78 & & PEL79 & & PEL9 & & PEL13 & & PEL35 & & PEL36 & \\
\hline $\mathrm{T}\left({ }^{\circ} \mathrm{C}\right)$ & 750 & & 750 & & 800 & & 850 & & 850 & & 850 & & 900 & & 900 & & 1000 & & 1000 & \\
\hline Duration (h) & 241 & & 241 & & 196 & & 170 & & 170 & & 170 & & 91 & & 91 & & 93 & & 93 & \\
\hline$S_{\text {in }}(\mathrm{wt} \%)$ & - & & 1 & & - & & - & & 1 & & 2.1 & & - & & 1 & & - & & 1 & \\
\hline D garnet-melt & & $1 \sigma$ & & $1 \sigma$ & & $1 \sigma$ & & $1 \sigma$ & & $1 \sigma$ & & $1 \sigma$ & & $1 \sigma$ & & $1 \sigma$ & & $1 \sigma$ & & $1 \sigma$ \\
\hline $\mathrm{Li}$ & 0.38 & 0.01 & 0.84 & - & 0.25 & 0.00 & 0.35 & 0.06 & 0.35 & 0.03 & 0.43 & 0.03 & 0.22 & 0.03 & 0.22 & 0.01 & 0.21 & 0.04 & 0.17 & 0.01 \\
\hline $\mathrm{Be}$ & - & - & - & - & - & - & - & - & - & - & - & - & - & - & - & - & - & - & - & - \\
\hline B & - & - & - & - & - & - & - & - & - & - & - & - & - & - & - & - & - & - & - & - \\
\hline $\mathrm{Rb}$ & - & - & 0.025 & - & 0.007 & 0.000 & - & - & - & - & - & - & - & - & 0.004 & 0.002 & - & - & - & - \\
\hline $\mathrm{Ba}$ & - & - & - & - & 0.007 & 0.000 & - & - & - & - & - & - & - & - & 0.004 & 0.002 & - & - & - & - \\
\hline Th & - & - & 0.285 & - & 0.020 & 0.000 & 0.076 & 0.013 & - & - & - & - & - & - & 0.004 & 0.002 & - & - & - & - \\
\hline $\mathrm{U}$ & 0.60 & 0.01 & 0.31 & - & - & - & 0.25 & 0.02 & - & - & - & - & 0.03 & 0.01 & 0.03 & 0.01 & 0.09 & 0.01 & - & - \\
\hline $\mathrm{Nb}$ & - & - & - & - & - & - & - & - & - & - & - & - & - & - & 0.04 & 0.02 & - & - & - & - \\
\hline $\mathrm{Ta}$ & - & - & - & - & - & - & - & - & - & - & - & - & - & - & - & - & - & - & - & - \\
\hline $\mathrm{La}$ & - & - & - & - & 0.01 & 0.00 & 0.02 & 0.00 & - & - & - & - & - & - & 0.003 & 0.001 & - & - & - & - \\
\hline $\mathrm{Ce}$ & 0.094 & 0.003 & 0.106 & - & 0.021 & 0.001 & 0.056 & 0.006 & 0.008 & 0.002 & 0.004 & 0.000 & 0.007 & 0.003 & 0.008 & 0.003 & 0.013 & 0.003 & 0.004 & 0.001 \\
\hline $\mathrm{Pb}$ & 0.115 & 0.016 & - & - & 0.014 & 0.001 & - & - & - & - & - & - & - & - & 0.003 & 0.001 & - & - & - & - \\
\hline $\mathrm{Sr}$ & 0.01 & 0.00 & 0.004 & - & 0.009 & 0.000 & - & - & - & - & - & - & 0.001 & 0.000 & 0.003 & 0.002 & 0.005 & 0.002 & - & - \\
\hline $\mathrm{Nd}$ & 1.86 & 0.01 & 0.86 & - & 0.37 & 0.00 & 0.67 & 0.05 & 0.13 & 0.01 & 0.06 & 0.01 & 0.11 & 0.04 & 0.10 & 0.03 & 0.17 & 0.02 & 0.06 & 0.01 \\
\hline $\mathrm{Sm}$ & - & - & - & - & 4.38 & 0.63 & 6.17 & 0.46 & 1.45 & 0.15 & 0.78 & 0.07 & 0.94 & 0.14 & 0.87 & 0.22 & 1.04 & 0.06 & 0.44 & 0.10 \\
\hline $\mathrm{Zr}$ & 3.62 & 0.07 & 1.84 & - & 1.51 & 0.00 & 2.57 & 0.03 & 1.21 & 0.04 & 0.69 & 0.05 & 1.32 & 0.08 & 1.08 & 0.16 & - & - & 0.69 & 0.08 \\
\hline Hf & - & - & - & - & 0.84 & 0.00 & 1.33 & 0.15 & 0.78 & 0.22 & 0.51 & 0.14 & 0.83 & 0.12 & 0.63 & 0.11 & 0.71 & 0.18 & 0.53 & 0.16 \\
\hline $\mathrm{Eu}$ & - & - & - & - & 11.08 & 0.38 & 6.63 & 0.96 & 2.57 & 0.28 & 1.28 & 0.22 & 1.16 & 0.16 & 1.54 & 0.32 & 0.70 & 0.08 & 0.64 & 0.25 \\
\hline $\mathrm{Ti}$ & 6.37 & 6.26 & 3.19 & 0.65 & 1.66 & 0.74 & 3.89 & 2.50 & 2.39 & 0.97 & 1.92 & 1.15 & 1.39 & 0.85 & 0.97 & 0.36 & 0.21 & 0.04 & 0.52 & 0.27 \\
\hline Dy & - & - & - & - & - & - & 210 & 28 & 156 & 21 & 15.2 & 1.0 & 48.6 & 8.7 & 17.2 & 3.7 & 13.0 & 3.0 & 5.26 & 0.62 \\
\hline Y & - & - & - & - & - & - & - & - & - & - & 25.79 & 1.59 & 87.50 & 23.82 & 27.81 & 6.07 & 19.14 & 5.66 & 7.02 & 0.92 \\
\hline $\mathrm{Yb}$ & - & - & - & - & - & - & 148 & 19 & 191 & 110 & 121 & 25 & 136 & 63 & 91.2 & 33.6 & 53.4 & 26.8 & 14.4 & 4.86 \\
\hline $\mathrm{Zr} / \mathrm{Hf}$ & - & - & - & - & 1.8 & 0.0 & 1.9 & 0.2 & 1.6 & 0.4 & 1.4 & 0.4 & 1.6 & 0.3 & 1.7 & 0.4 & - & - & 1.3 & 0.4 \\
\hline U/Th & - & - & 1.1 & - & - & - & 3.3 & 0.6 & - & - & - & - & - & - & 6.7 & 4.3 & - & - & - & - \\
\hline
\end{tabular}


Table 6: Orthopyroxene-melt partition coefficients

\begin{tabular}{|c|c|c|c|c|}
\hline Run no. & \multicolumn{2}{|l|}{ PEL79 } & \multicolumn{2}{|l|}{ PEL14 } \\
\hline $\mathrm{T}\left({ }^{\circ} \mathrm{C}\right)$ & \multicolumn{2}{|l|}{850} & \multicolumn{2}{|l|}{900} \\
\hline Duration (h) & \multicolumn{2}{|l|}{170} & \multicolumn{2}{|l|}{91} \\
\hline$S_{\text {in }}(\mathrm{wt} \%)$ & \multicolumn{2}{|l|}{2.1} & \multicolumn{2}{|l|}{2.1} \\
\hline \multicolumn{2}{|c|}{ D orthopyroxene-melt } & $1 \sigma$ & & $1 \sigma$ \\
\hline $\mathrm{Li}$ & 0.65 & 0.04 & 0.57 & 0.05 \\
\hline $\mathrm{Be}$ & - & - & 0.22 & 0.03 \\
\hline $\mathrm{B}$ & - & - & - & - \\
\hline $\mathrm{Rb}$ & - & - & - & - \\
\hline $\mathrm{Ba}$ & - & - & - & - \\
\hline Th & 0.129 & 0.005 & 0.023 & 0.002 \\
\hline $\mathrm{U}$ & - & - & 0.024 & 0.002 \\
\hline $\mathrm{Nb}$ & - & - & 0.32 & 0.02 \\
\hline $\mathrm{Ta}$ & - & - & 0.32 & 0.03 \\
\hline $\mathrm{La}$ & 0.009 & 0.000 & 0.004 & 0.000 \\
\hline $\mathrm{Ce}$ & 0.008 & 0.000 & 0.005 & 0.000 \\
\hline $\mathrm{Pb}$ & - & - & - & - \\
\hline $\mathrm{Sr}$ & 0.003 & 0.000 & 0.002 & 0.000 \\
\hline $\mathrm{Nd}$ & - & - & 0.009 & 0.000 \\
\hline $\mathrm{Sm}$ & - & - & - & - \\
\hline $\mathrm{Zr}$ & 0.05 & 0.00 & 0.06 & 0.00 \\
\hline $\mathrm{Hf}$ & - & - & 0.10 & 0.01 \\
\hline $\mathrm{Eu}$ & - & - & - & - \\
\hline $\mathrm{Ti}$ & 0.60 & 0.29 & 0.36 & 0.07 \\
\hline Dy & - & - & 0.11 & 0.00 \\
\hline $\mathrm{Y}$ & 0.13 & 0.01 & 0.08 & 0.00 \\
\hline $\mathrm{Yb}$ & - & - & 0.16 & 0.01 \\
\hline
\end{tabular}


Table 7: Phengite- and biotite-melt partition coefficients

\begin{tabular}{|c|c|c|c|c|c|c|c|c|c|c|}
\hline \multirow{3}{*}{$\begin{array}{l}\text { Run no. } \\
\mathrm{T}\left({ }^{\circ} \mathrm{C}\right) \\
\text { Duration } \\
\text { (h) }\end{array}$} & \multicolumn{2}{|l|}{ PEL71 } & \multicolumn{2}{|l|}{ PEL72 } & \multicolumn{2}{|l|}{ PEL50 } & \multicolumn{2}{|l|}{ PEL73 } & \multicolumn{2}{|l|}{ PEL52 } \\
\hline & 750 & & 750 & & 800 & & 750 & & 800 & \\
\hline & 241 & & 241 & & 196 & & 241 & & 196 & \\
\hline$S_{\text {in }}(\mathrm{wt} \%)$ & - & & 1 & & - & & 2.1 & & 2.1 & \\
\hline & $\mathrm{D}^{\mathrm{Ph} / \text { melt }}$ & $1 \sigma$ & $\mathrm{D}^{\mathrm{Ph} / \text { melt }}$ & $1 \sigma$ & $\mathrm{D}^{\mathrm{Ph} / \text { melt }}$ & $1 \sigma$ & $\mathrm{D}^{\mathrm{B} t / \mathrm{melt}}$ & $1 \sigma$ & $\mathrm{D}^{\mathrm{Bt} / \mathrm{melt}}$ & $1 \sigma$ \\
\hline $\mathrm{Li}$ & 0.61 & 0.01 & 0.58 & - & 0.30 & 0.00 & 0.65 & 0.04 & 0.49 & 0.05 \\
\hline $\mathrm{Be}$ & - & - & - & - & - & - & - & - & - & - \\
\hline B & 0.16 & 0.02 & 0.23 & - & - & - & 0.05 & 0.00 & - & - \\
\hline $\mathrm{Rb}$ & 3.72 & 0.15 & 4.04 & - & 2.67 & 0.07 & 3.69 & 0.09 & 3.68 & 0.42 \\
\hline $\mathrm{Ba}$ & 6.21 & 0.56 & 6.72 & - & 3.01 & 0.06 & 2.07 & 0.20 & 2.03 & 0.18 \\
\hline Th & 0.09 & 0.00 & 0.18 & - & - & - & 0.20 & 0.00 & 0.03 & 0.01 \\
\hline $\mathrm{U}$ & - & - & 0.60 & - & - & - & 0.16 & 0.01 & - & - \\
\hline $\mathrm{Nb}$ & 2.25 & 0.19 & 1.97 & - & 2.60 & 0.24 & 0.82 & 0.07 & 0.75 & 0.21 \\
\hline $\mathrm{Ta}$ & - & - & - & - & - & - & - & - & - & - \\
\hline $\mathrm{La}$ & 0.13 & 0.00 & 0.17 & - & - & - & 0.06 & 0.00 & - & - \\
\hline $\mathrm{Ce}$ & 0.12 & 0.00 & 0.17 & - & 0.01 & 0.00 & 0.06 & 0.01 & - & - \\
\hline $\mathrm{Pb}$ & 0.19 & 0.03 & 0.26 & - & 0.11 & 0.01 & 0.14 & 0.00 & 0.08 & 0.02 \\
\hline $\mathrm{Sr}$ & 0.41 & 0.02 & 0.43 & - & 0.18 & 0.01 & 0.09 & 0.01 & 0.05 & 0.01 \\
\hline $\mathrm{Nd}$ & - & - & - & - & - & - & 0.13 & 0.01 & - & - \\
\hline $\mathrm{Sm}$ & - & - & - & - & - & - & - & - & - & - \\
\hline $\mathrm{Zr}$ & 0.30 & 0.01 & - & - & 0.12 & 0.00 & 0.21 & 0.01 & 0.03 & 0.00 \\
\hline $\mathrm{Hf}$ & - & - & - & - & - & - & - & - & - & - \\
\hline $\mathrm{Eu}$ & - & - & - & - & - & - & - & - & - & - \\
\hline $\mathrm{Ti}$ & 11.55 & 16.74 & 3.39 & 0.60 & 4.91 & 1.49 & 15.01 & 9.68 & 12.10 & 5.16 \\
\hline Dy & - & - & - & - & - & - & - & - & - & - \\
\hline $\mathrm{Y}$ & - & - & - & - & - & - & 0.05 & 0.00 & - & - \\
\hline $\mathrm{Yb}$ & - & - & - & - & - & - & 0.70 & 0.07 & - & - \\
\hline
\end{tabular}


Table 8: $\mathrm{Pb}$ sulphide-melt partition coefficients

\begin{tabular}{|c|c|c|c|c|c|c|c|c|}
\hline Run no. & \multicolumn{2}{|c|}{ PEL52 } & \multicolumn{2}{|l|}{ PEL79 } & \multicolumn{2}{|c|}{ PEL13 } & \multicolumn{2}{|c|}{ PEL37 } \\
\hline $\mathrm{T}\left({ }^{\circ} \mathrm{C}\right)$ & 800 & & 850 & & 900 & & 1000 & \\
\hline Duration (h) & 196 & & 170 & & 91 & & 93 & \\
\hline $\mathrm{S}_{\mathrm{in}}(\mathrm{wt} \%)$ & 2.1 & & 2.1 & & 1 & & 2.1 & \\
\hline D sulphide-melt & & $1 \sigma$ & & $1 \sigma$ & & $1 \sigma$ & & $1 \sigma$ \\
\hline $\mathrm{Pb}$ & 0.40 & 0.23 & 0.44 & - & 0.13 & 0.00 & 0.54 & - \\
\hline
\end{tabular}

